\title{
Carbonyl sulfide: comparing a mechanistic representation of the vegetation uptake in a land surface model and the leaf relative uptake approach
}

\author{
Fabienne Maignan $^{1}$, Camille Abadie ${ }^{1}$, Marine Remaud ${ }^{1}$, Linda M. J. Kooijmans ${ }^{2}$, Kukka-Maaria Kohonen ${ }^{3}$, \\ Róisín Commane $^{4}$, Richard Wehr ${ }^{5}$, J. Elliott Campbell ${ }^{6}$, Sauveur Belviso ${ }^{1}$, Stephen A. Montzka ${ }^{7}$, Nina Raoult ${ }^{1}$, \\ Ulli Seibt ${ }^{8}$, Yoichi P. Shiga ${ }^{9}$, Nicolas Vuichard ${ }^{1}$, Mary E. Whelan ${ }^{10}$, and Philippe Peylin ${ }^{1}$ \\ ${ }^{1}$ Laboratoire des Sciences du Climat et de l'Environnement, LSCE/IPSL, CEA-CNRS-UVSQ, \\ Université Paris-Saclay, Gif-sur-Yvette, France \\ ${ }^{2}$ Meteorology and Air Quality, Wageningen University and Research, Wageningen, the Netherlands \\ ${ }^{3}$ Institute for Atmospheric and Earth System Research (INAR)/Physics, Faculty of Science, \\ University of Helsinki, Helsinki, Finland \\ ${ }^{4}$ Dept. Earth \& Environmental Sciences, Lamont-Doherty Earth Observatory of Columbia University, \\ New York, NY 10964, USA \\ ${ }^{5}$ Department of Ecology and Evolutionary Biology, University of Arizona, Tucson, USA \\ ${ }^{6}$ Sierra Nevada Research Institute, University of California, Merced, California 95343, USA \\ ${ }^{7}$ NOAA Global Monitoring Laboratory, Boulder, Colorado, USA \\ ${ }^{8}$ Dept of Atmospheric \& Oceanic Sciences, University of California Los Angeles, California 90095, USA \\ ${ }^{9}$ Universities Space Research Association, Mountain View, CA, USA \\ ${ }^{10}$ Department of Environmental Sciences, Rutgers University, New Brunswick, NJ 08901, USA
}

Correspondence: Fabienne Maignan (fabienne.maignan@lsce.ipsl.fr)

Received: 13 October 2020 - Discussion started: 5 November 2020

Revised: 28 February 2021 - Accepted: 11 March 2021 - Published: 12 May 2021

\begin{abstract}
Land surface modellers need measurable proxies to constrain the quantity of carbon dioxide $\left(\mathrm{CO}_{2}\right)$ assimilated by continental plants through photosynthesis, known as gross primary production (GPP). Carbonyl sulfide (COS), which is taken up by leaves through their stomates and then hydrolysed by photosynthetic enzymes, is a candidate GPP proxy. A former study with the ORCHIDEE land surface model used a fixed ratio of COS uptake to $\mathrm{CO}_{2}$ uptake normalised to respective ambient concentrations for each vegetation type (leaf relative uptake, LRU) to compute vegetation COS fluxes from GPP. The LRU approach is known to have limited accuracy since the LRU ratio changes with variables such as photosynthetically active radiation (PAR): while $\mathrm{CO}_{2}$ uptake slows under low light, COS uptake is not light limited. However, the LRU approach has been popular for COS-GPP proxy studies because of its ease of application and apparent low contribution to uncertainty for regional-scale appli-
\end{abstract}

cations. In this study we refined the COS-GPP relationship and implemented in ORCHIDEE a mechanistic model that describes COS uptake by continental vegetation. We compared the simulated COS fluxes against measured hourly COS fluxes at two sites and studied the model behaviour and links with environmental drivers. We performed simulations at a global scale, and we estimated the global COS uptake by vegetation to be $-756 \mathrm{Gg} \mathrm{Syr}^{-1}$, in the middle range of former studies ( -490 to $-1335 \mathrm{Gg} \mathrm{S} \mathrm{yr}^{-1}$ ). Based on monthly mean fluxes simulated by the mechanistic approach in ORCHIDEE, we derived new LRU values for the different vegetation types, ranging between 0.92 and 1.72 , close to recently published averages for observed values of 1.21 for $\mathrm{C}_{4}$ and 1.68 for $\mathrm{C}_{3}$ plants. We transported the COS using the monthly vegetation COS fluxes derived from both the mechanistic and the LRU approaches, and we evaluated the simulated COS concentrations at NOAA sites. Although 
the mechanistic approach was more appropriate when comparing to high-temporal-resolution COS flux measurements, both approaches gave similar results when transporting with monthly COS fluxes and evaluating COS concentrations at stations. In our study, uncertainties between these two approaches are of secondary importance compared to the uncertainties in the COS global budget, which are currently a limiting factor to the potential of COS concentrations to constrain GPP simulated by land surface models on the global scale.

\section{Introduction}

Humanity has to face the urgency of climate change if it hopes to limit adverse future impacts (Allen et al., 2018; IPCC, 2019a, b). In order to make reliable predictions of future climate, scientists have built powerful numerical Earth system models (ESMs), where they continuously integrate gained knowledge on a multitude of climate-related and climate-interacting processes. The carbon cycle is at the heart of the present global warming, caused by anthropogenic $\mathrm{CO}_{2}$ emissions (Ciais et al., 2013). In the global carbon budget, the land component shows the largest uncertainty (Le Quéré et al., 2018; Bloom et al., 2016). Land surface models (LSMs) struggle to accurately represent the large spatial and temporal variability of the $\mathrm{CO}_{2}$ gross and net fluxes (Anav et al., 2015). $\mathrm{CO}_{2}$ is first assimilated through plant photosynthesis, before being respired by the ecosystem. The quantity of assimilated carbon is called gross primary productivity (GPP). All other carbon fluxes and stocks derive from this first gross assimilation flux. To help reduce uncertainties in the estimated GPP, LSMs can benefit from knowledge obtained through local eddy covariance measurements of the net ecosystem-atmosphere $\mathrm{CO}_{2}$ exchange (Friend et al., 2007; Kuppel et al., 2014).

GPP proxies are also used, such as solar-induced fluorescence (Norton et al., 2019; Bacour et al., 2019), isotopic composition of atmospheric $\mathrm{CO}_{2}\left(\delta^{18} \mathrm{O}\right.$; Farquhar et al., 1993; Welp et al., 2011; $\delta^{13} \mathrm{C}$ : Peters et al., 2018), and carbonyl sulfide (COS) atmospheric concentrations (Hilton et al., 2015). Using atmospheric COS measurements as a tracer for terrestrial photosynthesis was first suggested by Sandoval-Soto et al. (2005) and Montzka et al. (2007), and Campbell et al. (2008) provided quantitative evidence using airborne observations of $\mathrm{COS}$ and $\mathrm{CO}_{2}$ concentrations and an atmospheric transport model. COS is an atmospheric trace gas that has a molecular structure very similar to $\mathrm{CO}_{2}$ and is likewise taken up by plants through stomates. COS is hydrolysed within the leaf, with this reaction being catalysed by the enzyme carbonic anhydrase (CA). This reaction is lightindependent (Protoschill-Krebs et al., 1996; Goldan et al., 1998) and, because of the high catalytic efficiency of this enzyme (Ogawa et al., 2013; Ogée et al., 2016; Protoschill-
Krebs et al., 1996), COS hydrolysis inside the leaf seems therefore to be limited by COS supply driven by changes in stomatal conductance (Goldan et al., 1988; Sandoval-Soto et al., 2005; Seibt et al., 2010; Stimler et al., 2010). Leaves' uptake of $\mathrm{COS}$ and $\mathrm{CO}_{2}$ is thus very similar, but leaves do not produce COS (Protoschill-Krebs et al., 1996; Notni et al., 2007), whereas they emit $\mathrm{CO}_{2}$ through respiration. That is why vegetation COS fluxes could be used as a proxy for GPP. It is however to be noted that Gimeno et al. (2017) reported COS emissions by bryophytes during daytime.

The approach generally adopted to constrain GPP with COS relies on the determination of a leaf relative uptake (LRU), which is the ratio of COS to $\mathrm{CO}_{2}$ uptake normalised by their atmospheric concentrations (Sandoval-Soto et al., 2005):

$\mathrm{LRU}=\frac{F_{\mathrm{COS}}\left[\mathrm{CO}_{2}\right]_{\mathrm{a}}}{\mathrm{GPP}[\mathrm{COS}]_{\mathrm{a}}}$,

where $F_{\mathrm{COS}}$ is the flux of COS uptake (pmol COS m$\left.{ }^{-2} \mathrm{~s}^{-1}\right)$, GPP is the gross flux of $\mathrm{CO}_{2}$ assimilation $\left(\mu \mathrm{mol} \mathrm{CO} \mathrm{m}^{-2} \mathrm{~s}^{-1}\right), \quad[\mathrm{COS}]_{\mathrm{a}}$ is the atmospheric COS mixing ratio (pmolCOS mol ${ }^{-1}, \mathrm{ppt}$ ), and $\left[\mathrm{CO}_{2}\right]_{\mathrm{a}}$ is the atmospheric $\mathrm{CO}_{2}$ mixing ratio ( $\left.\mu \mathrm{mol} \mathrm{CO} \mathrm{Col}^{-1}, \mathrm{ppm}\right)$.

LRU can be estimated experimentally and then used as a scaling factor for estimating GPP, if $F_{\mathrm{COS}},[\mathrm{COS}]_{\mathrm{a}}$, and $\left[\mathrm{CO}_{2}\right]_{\mathrm{a}}$ are available. Measurements can be made at the leaf level using branch chambers (Seibt et al., 2010; Kooijmans et al., 2019); LRU can also be estimated at the ecosystem level: eddy-covariance flux towers measure the ecosystem total COS flux (Kohonen et al., 2020), and removing the soil contribution gives access to the vegetation part (Wehr et al., 2017). Soil can absorb and emit COS (Whelan et al., 2016; Kitz et al., 2020), with the magnitude of their flux being generally much lower than that of vegetation fluxes (Berkelhammer et al., 2014; Maseyk et al., 2014; Wehr et al., 2017; Whelan et al., 2018). Epiphytes (lichen, mosses) could also have a significant contribution to the ecosystem COS budget (Kuhn and Kesselmeier, 2000; Rastogi et al., 2018).

However, LRU does not appear constant under some environmental conditions. For example, the fixation of carbon from $\mathrm{CO}_{2}$ relies on light-dependent reactions, unlike the uptake of COS by the CA enzyme, which is light-independent (Stimler et al., 2011). Because of these different responses of $\mathrm{COS}$ and $\mathrm{CO}_{2}$ uptake in leaves, LRU varies with light conditions and decreases sharply with PAR increase (Stimler et al., 2010; Maseyk et al., 2014; Commane et al., 2015; Wehr et al., 2017; Yang et al., 2018). Consequently, LRU values are smaller at midday or in seasons with high incoming light (Kooijmans et al., 2019). Moreover, COS assimilation continues at night as stomatal conductance to gas transfer does not drop to zero, whereas $\mathrm{CO}_{2}$ uptake by plants stops, leading to an infinite value of LRU. Note however that stomates mostly close at night, so the COS uptake at night is smaller than the COS uptake during the day. The diel (i.e. 24-hourly) variation in LRU with light may however be only of second- 
order importance as GPP is very low at low light, and Yang et al. (2018) found that considering sub-daily variations in LRU when computing daily mean GPP values had no importance. It has also been shown that LRU varies between plant species (Stimler et al., 2011), which is why different LRU values were estimated for different vegetation types (Seibt et al., 2010; Whelan et al., 2018). The variability of LRU with plant type and over a day and season (inferred by changes in light conditions) should therefore be carefully accounted for when COS concentrations or flux measurements are used to estimate GPP at the ecosystem and larger scales. We also have to acknowledge that there are still factors that are not accounted for if discrepancies between GPP and COS-based estimations are larger than their estimated respective uncertainties.

Before being able to use COS observations to constrain the simulated GPP, land surface models (LSMs) first need to have an accurate model to simulate vegetation COS fluxes. In a former study, Launois et al. (2015b) simply defined the COS uptake by vegetation as the $\mathrm{CO}_{2}$ gross uptake simulated by LSMs, scaled with a constant LRU value for each large vegetation class. The goal of this study is to now simulate the uptake of atmospheric COS by continental vegetation in a more complex and realistic way using a mechanistic approach within an LSM and apply this model to evidence the shortcomings or pertinence of the LRU concept, depending on the studied scales.

i. We used the state-of-the art ORCHIDEE LSM (Krinner et al., 2015), and we implemented in it the vegetation COS uptake model of Berry et al. (2013) to simulate the COS fluxes absorbed at the leaf and canopy levels by the continental vegetation.

ii. We evaluated the simulated COS fluxes against measurements at two forest sites, namely the Harvard Forest, United States (Wehr et al., 2017), and Hyytiälä, Finland (Kooijmans et al., 2019; Kohonen et al., 2020; Sun et al., 2018a). We studied the high-frequency behaviour of the modelled conductances over the season and the dependency of the LRU on the environmental and structural conditions.

iii. We compared the simulated mechanistic COS fluxes at the global scale to former estimates; we studied LRU values estimated from monthly fluxes, which are pertinent for atmospheric studies, and compared them to monthly means of high-frequency LRU values.

iv. The mechanistic and LRU simulated COS fluxes were used with the atmospheric transport model LMDz (Hourdin et al., 2006), to provide atmospheric COS concentrations that were evaluated against measurements at sites of the NOAA network.
2 Models, data, and methodology

\subsection{Implementation of plant COS uptake in the ORCHIDEE LSM to simulate COS vegetation fluxes}

\subsubsection{The ORCHIDEE LSM}

ORCHIDEE is an LSM developed mainly at Institut Pierre Simon Laplace (IPSL) that computes the water, carbon, and energy balances at the interface between land surfaces and atmosphere (Krinner et al., 2005). Fast processes including hydrology, photosynthesis, and energy balance are run at a half-hourly time step, while other slower processes such as carbon allocation and mortality are simulated at a daily time step. The sub-grid variability for vegetation is represented using fractions of plant functional types (PFTs), grouping plants with similar morphologies and behaviours growing under similar climatic conditions. Photosynthesis follows the Yin and Struik (2009) approach, bringing improvements to the standard Farquhar et al. (1980) model for $\mathrm{C}_{3}$ plants, the Collatz et al. (1992) model for $\mathrm{C}_{4}$ plants, and the Ball et al. (1987) model for the stomatal conductance. A main novelty is the introduction of a mesophyll conductance linking the $\mathrm{CO}_{2}$ concentration at the carboxylation sites, $C_{\mathrm{c}}$, to the $\mathrm{CO}_{2}$ intracellular concentration, $C_{\mathrm{i}}$. For each PFT, the reference value for the maximum photosynthetic capacity at $25^{\circ} \mathrm{C}, V_{\max , 25}$, is derived from literature survey and observation databases and possibly later calibrated using FLUXNET observations (e.g. Kuppel et al., 2012). To compute the maximum photosynthetic capacity at leaf level, $V_{\max }$, the reference value is multiplied at a daily time step by the relative photosynthetic efficiency of leaves based on the mean leaf age following Ishida et al. (1999) (see Eq. A12 and Fig. A12 in Krinner et al., 2005). Leaves are very efficient when they are young and stay so till they approach their pre-defined leaf lifespan. The temperature dependence of the maximum photosynthetic capacity follows Medlyn et al. (2002) and Kattge and Knorr (2007). A water stress function varying between 0 and 1 depending on soil moisture and root profile (de Rosnay and Polcher, 1998) is applied on maximum photosynthetic capacity and conductances. The canopy is discretised in several layers of growing thickness, the number depending on the actual leaf area index (LAI). All the incoming light is considered to be diffuse, and no distinction is made between sun and shaded leaves. The light is attenuated through the canopy following a simple Beer-Lambert absorption law. The $\mathrm{CO}_{2}$ assimilation, the stomatal conductance, and the intercellular $\mathrm{CO}_{2}$ concentration $C_{\mathrm{i}}$ are computed per LAI layer, provided LAI is higher than 0.01 and the monthly mean air temperature is higher than $-4{ }^{\circ} \mathrm{C}$. The $\mathrm{CO}_{2}$ assimilation and the stomatal conductance are further summed up over all layers to compute GPP and the total conductance at canopy level. The scaling to the grid cell is made using means weighted by the plant functional type fractions. Phenology is 
fully prognostic with PFT-specific phenological models as described in Botta et al. (2000) and MacBean et al. (2015). ORCHIDEE can be run from the site scale to the global scale, coupled with an atmospheric general circulation model, or in off-line mode forced by meteorological fields. In this study, we prescribed the vegetation distribution for site simulations and used yearly PFT maps derived from the ESA Climate Change Initiative (CCI) land cover products for global simulations (Poulter et al., 2015). The soil type is derived from the Zobler map (Zobler, 1986). To account for the $\mathrm{CO}_{2}$ fertilisation effect, we considered global means of $\left[\mathrm{CO}_{2}\right]_{\mathrm{a}}$ with yearly varying values, as provided by the TRENDY model inter-comparison project (Sitch et al., 2015). The impact of not taking into account the spatial and temporal variations in $\left[\mathrm{CO}_{2}\right]_{\mathrm{a}}$ on GPP has been studied in Lee et al. (2020); while this simplification has indeed no impact at a global yearly scale for GPP, this may be less true at site and seasonal scales. We used the recent ORCHIDEE version fine-tuned for the Climate Model Intercomparison Project (CMIP) 6 exercise (Boucher et al., 2020), forced by micro-meteorology fields at FLUXNET sites or by $2^{\circ}$ CRUNCEP reanalyses at the global scale (https://rda.ucar.edu/datasets/ds314.3/, last access: 19 April 2021).

\subsubsection{The Berry model for plant COS uptake}

In the ORCHIDEE LSM we implemented the mechanistic model of plant COS uptake based on Berry et al. (2013). In this model, COS follows a diffusive law from the atmosphere to the leaf interior, where it is consumed by CA in the chloroplasts. The uptake from the atmosphere is assumed to be unidirectional, reflecting the fact that COS is generally not produced by plants. The model distinguishes three conductances along the COS path between the atmosphere and the leaf interior: (1) the boundary layer conductance $\left(g_{\mathrm{B}} \mathrm{COS}\right)$ to gas transfer between the leaf surface and the atmosphere, (2) the stomatal conductance ( $\left.g_{\text {S_COS }}\right)$, and (3) the internal conductance ( $\left.g_{\text {I_COS }}\right)$. Internal conductance combines the mesophyll conductance and the CA activity into a single equivalent conductance.

The stomatal and boundary layer conductances are associated with factors describing diffusion of COS relative to that of water vapour (1.94 and 1.56, respectively; Stimler et al., 2010). In the chloroplast, the COS hydrolysis is catalysed by the enzyme CA, following first-order kinetics. COS uptake depends on the amount of CA and its relative location to intercellular air spaces, which brings in the mesophyll conductance. These two factors have been shown to scale with the maximum reaction rate of the Rubisco enzyme, $V_{\max }\left(\mu \mathrm{mol} \mathrm{m} \mathrm{m}^{-2} \mathrm{~s}^{-1}\right)$ (Badger and Price, 1994; Evans et al., 1994). The mesophyll conductance and the first-rate constant are then regrouped into a single equivalent internal conductance, proportional to $V_{\max }$ : $g_{\text {I_COS }}=\alpha \times V_{\max }$.

The parameter $\alpha$ takes two values depending on the plant photosynthetic pathway $\left(\mathrm{C}_{3}\right.$ or $\left.\mathrm{C}_{4}\right)$. These values were determined experimentally by Berry et al. (2013), who estimated an $\alpha=0.0012$ for $\mathrm{C}_{3}$ and an $\alpha=0.013$ for $\mathrm{C}_{4}$ species. We thus have the final equation:

$$
\begin{aligned}
& F_{\mathrm{COS}}=[\mathrm{COS}]_{\mathrm{a}} \times g_{\mathrm{T} \_\mathrm{COS}}=[\mathrm{COS}]_{\mathrm{a}} \\
& \times\left[\frac{1.0}{g_{\mathrm{B} \_\mathrm{COS}}}+\frac{1.0}{g_{\mathrm{S} \_\mathrm{COS}}}+\frac{1.0}{g_{\mathrm{I} \_\mathrm{COS}}}\right]^{-1}=[\mathrm{COS}]_{\mathrm{a}} \\
& \times\left[\frac{1.56}{g_{\mathrm{B} \_\mathrm{W}}}+\frac{1.94}{g_{\mathrm{S} \_\mathrm{W}}}+\frac{1.0}{g_{\mathrm{I} \_\mathrm{COS}}}\right]^{-1},
\end{aligned}
$$

where $F_{\mathrm{COS}}$ is the flux of COS uptake (pmol $\operatorname{COS~m}^{-2} \mathrm{~s}^{-1}$ ); $[\mathrm{COS}]_{\mathrm{a}}$ is the background atmospheric COS mixing ratio considered here to be a constant (500 ppt); $g_{T_{-} C O S}, g_{\text {B_COS }}$, $g_{\text {S_COS, and }} g_{\text {I_COS }}$ are respectively the total, boundary layer, stomatal, and internal conductances to COS (mol COS $\mathrm{m}^{-2} \mathrm{~s}^{-1}$ ); and $g_{\mathrm{B}} \mathrm{W}$ and $g_{\mathrm{S}} \mathrm{W}$ are respectively the boundary layer and stomatal conductances to water vapour (mol $\mathrm{H}_{2} \mathrm{O} \mathrm{m}^{-2} \mathrm{~s}^{-1}$ ). Note that in this work $[\mathrm{COS}]_{\mathrm{a}}$ is held constant when computing the COS fluxes, contrary to Berry et al. (2013) and Campbell et al. (2017), where $[\mathrm{COS}]_{\mathrm{a}}$ is dynamic and taken from the previous time step's PCTM (Parameterized Chemical Transport Model) value. The uncertainty introduced by this simplification is evaluated in the Discussion section. The vegetation COS flux and related conductances are computed for each LAI layer and then summed up to get total values at the canopy level. Unless specified otherwise, fluxes, conductances and LRU are further presented and discussed at the canopy level.

\subsubsection{Minimal conductances}

As plant $\mathrm{CO}_{2}$ uptake only occurs under certain conditions such as with sufficient light, temperature, and water, $\mathrm{CO}_{2}$ assimilation is not calculated in ORCHIDEE when these conditions are not fulfilled. Therefore, the stomatal conductance to $\mathrm{CO}_{2}$ that is needed to obtain the stomatal conductance to COS is not always computed in ORCHIDEE. However, some studies have shown incomplete stomatal closure at night (Dawson et al., 2007; Lombardozzi et al., 2017; Kooijmans et al., 2019), leading to nighttime COS plant uptake (Berry et al., 2013; Kooijmans et al., 2017). Therefore, we had to define a minimal stomatal conductance to $\operatorname{COS}$ under these particular conditions when there is no $\mathrm{CO}_{2}$ assimilation. The minimal conductance to $\mathrm{CO}_{2}$ used in ORCHIDEE is based on the residual stomatal conductance if the irradiance approaches zero, represented as the $g_{0}$ offset in the stomatal conductance models (see Eq. 15 for $\mathrm{C}_{3}$ and Eq. 25 for $\mathrm{C}_{4}$ plants in Yin and Struik, 2009). In the absence of water stress, $g_{0}$ takes a constant value for $\mathrm{C}_{3}\left(0.00625 \mathrm{~mol} \mathrm{CO}_{2} \mathrm{~m}^{-2} \mathrm{~s}^{-1}\right)$ 
and $\mathrm{C}_{4}\left(0.01875 \mathrm{~mol} \mathrm{CO}_{2} \mathrm{~m}^{-2} \mathrm{~s}^{-1}\right)$ plants. This constant is multiplied by a water stress function to compute the minimal conductance. This minimal conductance to $\mathrm{CO}_{2}$ was then applied under conditions when there is no $\mathrm{CO}_{2}$ assimilation, multiplied by the ratio to convert the conductance to $\mathrm{CO}_{2}$ into a conductance to COS. We thus model COS assimilation even at night, for all PFTs, and in winter for evergreen species, depending on water stress conditions.

\subsubsection{Simulations protocol}

All simulations were preceded by a "spin-up" phase to get to an equilibrium state where the considered carbon pools and fluxes are stable with no residual trends in the absence of any disturbances (climate, land use change, $\mathrm{CO}_{2}$ atmospheric concentrations) (e.g. Wei et al., 2014). A few decades are enough to equilibrate above-ground biomass and GPP. As we transport not only COS, but also $\mathrm{CO}_{2}$ (see Sect. 2.4 below), we need a longer spin-up where all carbon pools including those in the soil are stable and the net $\mathrm{CO}_{2}$ fluxes oscillate around zero. Equilibrating the ecosystem photosynthesis with its respiration takes a long time as the slowest soil carbon pool has a residence time on the order of 1000 years. The ORCHIDEE model has a built-in spin-up procedure to accelerate the convergence towards this equilibrium state, using a pseudo-analytical iterative estimation of the targeted carbon pools, based on Lardy et al. (2011). For global simulations, we first performed a 340-year spin-up phase with non-varying pre-industrial atmospheric $\mathrm{CO}_{2}$ concentration and vegetation map, cycling over the same 10 years of meteorological forcing files, where the final relative variation in the global slowest soil carbon pool was less than $5 \%$. Starting from this equilibrium state, a transient state simulation was then run applying climate change, land use change, and increasing $\mathrm{CO}_{2}$ atmospheric concentrations, and $\mathrm{COS}$ and GPP fluxes were calculated from 1860 to 2017. We performed site simulations at the Harvard Forest (United States) and Hyytiälä (Finland) FLUXNET sites (see below). For the two sites, we first performed a spin-up simulation cycling over the available years of the FLUXNET forcing files, for around 340 years, using a constant atmospheric $\mathrm{CO}_{2}$ concentration corresponding to the first year of the FLUXNET forcing file. We then performed the transient simulations over the available FLUXNET years, for each site, with a varying $\mathrm{CO}_{2}$ atmospheric concentration.

\subsection{Evaluation of vegetation COS fluxes at two FLUXNET sites}

Vegetation COS fluxes can be measured using branch chambers or estimated using the difference between measurements of ecosystem and soil fluxes. Such measurements were available at the Hyytiälä (Finland) and Harvard Forest (United States) FLUXNET sites. The Hyytiälä site $\left(61.85^{\circ} \mathrm{N}, 24.29^{\circ} \mathrm{E}\right)$ is a boreal evergreen needleleaf forest dominated by Scots pine (Pinus sylvestris). Branch measurements of COS fluxes were made in a Scots pine tree from March to July 2017 using gas-exchange chambers (Kooijmans et al., 2019); fluxes were derived from mole fraction changes when the chambers were closed once every hour. Measurements were made with an Aerodyne quantum cascade laser spectrometer (QCLS) and were calibrated against reference standards (Kooijmans et al., 2016). Fluxes from empty chambers were regularly measured to be able to correct for gas exchange by the chamber and tubing material (Kooijmans et al., 2019). We also used the Hyytiälä COS ecosystem fluxes (Kohonen et al., 2020); eddy covariance fluxes were measured during the years 2013-2017 at $23 \mathrm{~m}$ height, approximately $6 \mathrm{~m}$ above the canopy height. Flux data were processed, quality-screened, and gap-filled according to recommendations by Kohonen et al. (2020). Soil fluxes were also available for the year 2015 (Sun et al., 2018a). We thus derived the COS vegetation fluxes at the canopy scale for that year from the difference between ecosystem and soil fluxes. Soil fluxes were generally low compared to plant uptake.

The Harvard Forest site $\left(42.54^{\circ} \mathrm{N}, 72.17^{\circ} \mathrm{W}\right)$ is a temperate deciduous broadleaf forest with mainly red oak (Quercus rubra), red maple (Acer rubrum), and hemlock (Tsuga canadensis). Ecosystem COS eddy flux measurements were carried out from a tower from May to October, in 2012 and 2013, using an Aerodyne QCLS and calibrated using gas cylinders. They were further split into vegetation and soil components, using soil chamber $\mathrm{CO}_{2}$ measurements and a sub-canopy flux-gradient approach (Wehr et al., 2017).

The simulated COS fluxes were evaluated against measurements using the root-mean-square deviation:

$\mathrm{RMSD}=\sqrt{\frac{\sum_{n=1}^{N}\left(F_{\mathrm{COS}}^{\mathrm{Obs}}(n)-F_{\mathrm{COS}}^{\mathrm{Mod}}(n)\right)^{2}}{N}}$,

where $N$ is the number of considered observations, $F_{\mathrm{COS}}^{\mathrm{Obs}}(n)$ is the $n$th observed COS flux, and $F_{\mathrm{COS}}^{\mathrm{Mod}}(n)$ is the $n$th modelled COS flux, and the relative RMSD

$r \mathrm{RMSD}=\frac{\mathrm{RMSD}}{\overline{F_{\mathrm{COS}}^{\mathrm{Obs}}}}$,

which is the RMSD divided by the mean value of observations. 
We also computed the bias, standard deviations, and correlation coefficient.

$$
\begin{aligned}
& \text { bias }=\overline{F_{\mathrm{COS}}^{\mathrm{Mod}}}-\overline{F_{\mathrm{COS}}^{\mathrm{Obs}}} \\
& \mathrm{SD}^{\mathrm{Mod}}=\sqrt{\frac{\sum_{n=1}^{N}\left(F_{\mathrm{COS}}^{\mathrm{Mod}}(n)-\overline{F_{\mathrm{COS}}^{\mathrm{Mod}}}\right)^{2}}{N} \mathrm{SD}^{\mathrm{Obs}}} \\
& =\sqrt{\frac{\sum_{n=1}^{N}\left(F_{\mathrm{COS}}^{\mathrm{Obs}}(n)-\overline{F_{\mathrm{COS}}^{\mathrm{Obs}}}\right)^{2}}{N}} \\
& r=\frac{\sum_{n=1}^{N}\left(F_{\mathrm{COS}}^{\mathrm{Obs}}(n)-\overline{F_{\mathrm{COS}}^{\mathrm{Obs}}}\right) \cdot\left(F_{\mathrm{COS}}^{\mathrm{Mod}}(n)-\overline{F_{\mathrm{COS}}^{\mathrm{Mod}}}\right)}{N \cdot \mathrm{SD}^{\mathrm{Obs}} \cdot \mathrm{SD}^{\mathrm{Mod}}}
\end{aligned}
$$

We used partial correlations to identify the main drivers of the modelled conductances. Given the high non-linearity of the equations linking the conductances to their predictors, we also used random forests (RFs) to simulate ORCHIDEE results, and we applied a permutation technique on these RF models to rank predictors (Breiman, 2001). RFs are well adapted for non-linear problems; they were for example used to rank variables of importance for soil COS fluxes in Spielman et al. (2020).

\subsection{Global-scale flux estimates and comparisons with the LRU approach}

We compared our estimate for plant COS uptake at global scale to former studies, with a focus on the LRU approach. We also applied the LRU approach to derive new estimates of global plant COS uptake for comparison, using a monthly climatology of our modelled GPP fluxes over the 2000-2009 period, a constant atmospheric concentration of $500 \mathrm{ppt}$ for $\mathrm{COS}$ and global yearly values for $\mathrm{CO}_{2}$ (from $368 \mathrm{ppm}$ for the year 2000 to $386 \mathrm{ppm}$ for the year 2009). We considered two sets of constant PFT-dependent LRU values. The first set (LRU_Seibt) was taken from Seibt et al. (2010), based on the observed LRU values displayed in their Table 3 (intermediate column). The second set (LRU_Whelan) used constant values for $\mathrm{C}_{3}$ (1.68) and $\mathrm{C}_{4}$ (1.21) plants where the values are an average over different field and laboratory measurements as assembled by Whelan et al. (2018). Both sets are listed in Table 1.

Reciprocally, we derived LRU values using Eq. (1) applied to the monthly climatology of our modelled COS and GPP fluxes over the 2000-2009 period; these will be further called LRU_MonthlyFluxes values. LRU_MonthlyFluxes values were computed for all strictly positive GPP values. For each PFT, we studied the spatio-temporal distribution of LRU_MonthlyFluxes values among grid cells where the PFT was present. We also compared these LRU_MonthlyFluxes values computed from a climatology of monthly fluxes to the climatology of monthly mean LRU values, directly computed from the original half-hourly LRU values and further called Monthly_LRU. Given the non-linearity of the problem, we expect LRU_MonthlyFluxes to be different from Monthly_LRU values. Considering that the objective of the LRU approach was to estimate COS fluxes from GPP using a constant value per PFT, the optimal LRU value for each PFT was obtained by linearly regressing monthly COS fluxes against monthly GPP fluxes multiplied by the ratio of the mean $\mathrm{COS}$ to $\mathrm{CO}_{2}$ concentrations, with no offset. Thus

$$
\text { LRU_Opt }=\frac{\sum_{n=1}^{N} F_{\mathrm{COS}}^{\mathrm{Mod}}(n) \mathrm{GPP}^{\mathrm{Mod}}(n) \frac{[\operatorname{COS}(n)]_{\mathrm{a}}}{\left[\mathrm{CO}_{2}(n)\right]_{\mathrm{a}}}}{\sum_{n=1}^{N}\left(F_{\mathrm{COS}}^{\mathrm{Mod}}(n)\right)^{2}},
$$

with $N$ the number of grid cell month simulated fluxes where the PFT is present in the monthly climatology.

We compared this new set of optimal PFT-dependent LRU values against LRU_Seibt and LRU_Whelan.

We finally used the LRU_Opt values to re-compute the monthly mean COS fluxes from our modelled monthly mean GPP and compared with the mechanistic COS flux calculation. The differences, due to the non-linearity of the COS flux calculation, provide some information on the use of a simplified approach based on mean LRU values.

\subsection{Simulations of COS concentrations and evaluation at NOAA air sampling sites}

The vegetation COS fluxes, as well as all other sources and sinks of the global COS budget, based on their latest estimates, are transported with an atmospheric transport model, so that we are able to simulate 3D COS atmospheric concentrations and compare them to the NOAA surface measurements.

\subsubsection{The atmospheric transport model LMDz}

In order to simulate $\mathrm{COS}$ and $\mathrm{CO}_{2}$ concentrations in the atmosphere, we used the version of the atmospheric component LMDz of the Institut Pierre Simon Laplace Coupled Model (IPSL-CM) (Dufresne et al., 2013), which has been contributing to the CMIP6 exercise. To reduce the computation time, we used its off-line mode: precomputed air mass fluxes provided by the full version of $\mathrm{LMDz}$ are used to transport the different tracers (Hourdin et al., 2006). This version is further called LMDz6 and is described in Remaud et al. (2018) and references therein for the transport of $\mathrm{CO}_{2}$. The horizontal winds are nudged towards ECMWF meteorological analyses (ERA-5, https://www.ecmwf.int/en/forecasts/datasets/ archive-datasets/reanalysis-datasets/era5) to realistically account for large-scale advection. The tropospheric $\mathrm{OH}$ oxidation of $\mathrm{COS}$ is calculated from $\mathrm{OH}$ monthly data that are produced from a first simulation done with the INCA tropospheric photochemistry scheme (Folberth et al., 2006; Hauglustaine et al., 2004, 2014). The photolysis reaction of 
Table 1. Table of LRU per PFT. First column: median and optimal LRU values calculated from the simulated mechanistic COS and GPP fluxes. Middle columns: calculated from Seibt et al. (2010) for the ORCHIDEE PFT classification. Last column: from Whelan et al. (2018).

\begin{tabular}{|c|c|c|c|c|c|}
\hline \multicolumn{2}{|l|}{ PFT } & \multicolumn{2}{|c|}{ ORCHIDEE } & \multirow[t]{2}{*}{ Seibt } & \multirow[t]{2}{*}{ Whelan } \\
\hline Long name & Abbreviation & Median & Optimal & & \\
\hline 1 - Bare soil & Bare & 0.00 & 0.00 & 0.00 & 0.00 \\
\hline 2 - Tropical broadleaved evergreen forest & TroBroEver & 1.56 & 1.72 & 3.09 & 1.68 \\
\hline 3 - Tropical broadleaved raingreen forest & TroBroRain & 1.48 & 1.62 & 3.38 & 1.68 \\
\hline 4 - Temperate needleleaf evergreen forest & TempNeedleEver & 1.17 & 1.39 & 1.89 & 1.68 \\
\hline 5 - Temperate broadleaved evergreen forest & TempBroEver & 0.86 & 1.06 & 3.60 & 1.68 \\
\hline 6 - Temperate broadleaved summergreen forest & TempBroSum & 1.06 & 1.31 & 3.60 & 1.68 \\
\hline 7 - Boreal needleleaf evergreen forest & BorNeedleEver & 0.82 & 0.95 & 1.89 & 1.68 \\
\hline 8 - Boreal broadleaved summergreen forest & BorBroSum & 0.84 & 1.03 & 1.94 & 1.68 \\
\hline 9 - Boreal needleleaf summergreen forest & BorNeedleSum & 0.76 & 0.92 & 1.89 & 1.68 \\
\hline 10 - Temperate $C_{3}$ grass & Temp $\mathrm{C}_{3}$ grass & 1.01 & 1.18 & 2.53 & 1.68 \\
\hline $11-\mathrm{C}_{4}$ grass & C4grass & 1.38 & 1.45 & 2.00 & 1.21 \\
\hline $12-\mathrm{C}_{3}$ agriculture & $\mathrm{C}_{3}$ crops & 1.21 & 1.37 & 2.26 & 1.68 \\
\hline $13-\mathrm{C}_{4}$ agriculture & $\mathrm{C}_{4}$ crops & 1.75 & 1.72 & 2.00 & 1.21 \\
\hline $14-$ Tropical $\mathrm{C}_{3}$ grass & Trop $\mathrm{C}_{3}$ grass & 1.40 & 1.52 & 2.39 & 1.68 \\
\hline 15 - Boreal $C_{3}$ grass & Bor $\mathrm{C}_{3}$ grass & 0.87 & 0.97 & 2.02 & 1.68 \\
\hline
\end{tabular}

COS in the stratosphere is not considered: the lifetime of COS in the stratosphere is 64 years (Barkley et al., 2008). The model is set up at a horizontal resolution of $3.8^{\circ} \times 1.9^{\circ}$ (96 grid cells in longitude and latitude) with 39 hybrid sigmapressure levels reaching an altitude up to about $75 \mathrm{~km}$, corresponding to a vertical resolution of about $200-300 \mathrm{~m}$ in the planetary boundary layer. The model time step is $30 \mathrm{~min}$, and the output concentrations are 3-hourly averaged.

\subsubsection{Atmospheric simulations: sampling methods and data processing}

We ran the LMDz6 version of the atmospheric transport model described above for the years 2000 to 2009. The prescribed $\mathrm{COS}$ and $\mathrm{CO}_{2}$ fluxes used as model inputs are presented in Tables 2 and 3. The GPP estimated by ORCHIDEE

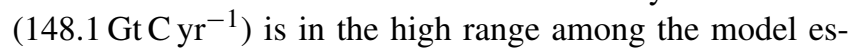
timates (Anav et al., 2015), with a corresponding high res-

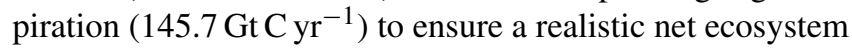
exchange (Friedlingstein et al., 2019). However, other high GPP estimates can be found in the literature such as Welp et al. (2011) that suggest a range of 150 to 175 based on $\delta^{18} \mathrm{O}$ data. Likewise, Joiner et al. (2018) have proposed a new GPP product, based on satellite data and calibrated on FLUXNET

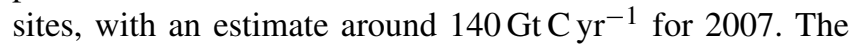
fluxes are given as a lower boundary condition of the atmospheric transport model (LMDz), which then simulates the transport of $\mathrm{COS}$ and $\mathrm{CO}_{2}$ by the atmospheric flow. The atmospheric COS seasonal variations are likely to be dominated by the seasonal exchange with the terrestrial vegetation, while the mean mole fractions result from all sources and sinks of COS, some of which are still largely unknown (e.g. ocean fluxes, Whelan et al., 2018). In this study, we only focus on the seasonal cycle and do not attempt to simulate the annual mean value; we thus started from a null initial state. The atmospheric transport is almost linear with respect to the fluxes: the linearity is a property of the atmospheric transport, though it is violated in $\mathrm{LMDz}$ because of the presence of slope limiters in the advection scheme. Overall, since all the other LMDz components are linear, LMDz transport is generally considered linear with fluxes (Hourdin and Talagrand, 2006). Relying on this relationship, we first transported each flux separately, and then we added all the simulated concentrations in the end, for each species.

For all $\mathrm{COS}$ and $\mathrm{CO}_{2}$ observations, the model output was sampled at the nearest grid point and vertical level to each station and was extracted at the exact hour when each flask sample had been taken. For each station, the curvefitting procedure developed by the NOAA Climate Monitoring and Diagnostic Laboratory (NOAA/CMDL) (Thoning, 1989) was applied to modelled and observed $\mathrm{COS}$ and $\mathrm{CO}_{2}$ time series to extract a smooth detrended seasonal cycle. We first fitted a function including a second-order polynomial term and four harmonic terms, and then we applied a lowpass filter with either 80 or $667 \mathrm{~d}$ as short-term and long-term cut-off values, respectively, to the residuals. The detrended seasonal cycle is defined as the smooth curve (full function plus short-term residuals) minus the trend curve (polynomial plus long-term residuals). 
Table 2. Prescribed COS surface fluxes used as model input. Mean magnitudes of different types of fluxes are given for the period 2000-2009.

\begin{tabular}{llrl}
\hline Type of COS flux & Temporal resolution & Total $\left(\mathrm{Gg} \mathrm{S} \mathrm{yr}^{-1}\right)$ & Data source \\
\hline Anthropogenic & Monthly, interannual & 337.3 & Zumkehr et al. (2018) \\
\hline Biomass burning & Monthly, interannual & 56.3 & Stinecipher et al. (2019) \\
\hline Soil & Monthly, climatological & -409.0 & Launois et al. (2015b) \\
\hline Ocean & Monthly, climatological & 444.7 & $\begin{array}{l}\text { Kettle (2002) for indirect oceanic emissions (via CS2 and } \\
\text { DMS oxidation), and Launois et al. (2015a) for direct oceanic } \\
\text { emissions. The direct emissions are rescaled to be equal to } \\
\text { 200 Gg s yr }\end{array}$ \\
\hline
\end{tabular}

Vegetation uptake Monthly, interannual

See Table 1. This work, including mechanistic and LRU approaches (Seibt et al., 2010; Whelan et al., 2018)

\footnotetext{
* A bug has been discovered in the parameterisation of direct COS emissions in the NEMO PISCES ocean model: the hydrolysis rate was 3 times too low, resulting in an artificial build-up of COS in seawaters. As a correction, we divided the total amount of oceanic COS fluxes within a year by 3 , assuming that the bug does not affect the spatial pattern of direct emissions of COS.
}

Table 3. Prescribed $\mathrm{CO}_{2}$ surface fluxes used as model input. Mean magnitudes of different types of fluxes are given for the period 2000-2009.

\begin{tabular}{llrl}
\hline Type of $\mathrm{CO}_{2}$ flux & Temporal resolution & Total $\left(\mathrm{Gt} \mathrm{Cyr}^{-1}\right)$ & Data source \\
\hline Fossil fuel & Monthly, interannual & 7.7 & ECJRC/PBL EDGAR version 4.2 \\
\hline Biomass burning & Monthly, interannual & 1.9 & GFED 4.1s \\
\hline $\begin{array}{l}\text { Respiration (including the land } \\
\text { use emissions and wood harvest) }\end{array}$ & Monthly, interannual & 145.7 & ORCHIDEE \\
\hline Ocean & Monthly, climatological & -1.3 & Landschützer et al. (2015) \\
\hline GPP & Monthly, interannual & -148.1 & ORCHIDEE \\
\hline
\end{tabular}

\subsubsection{COS and $\mathrm{CO}_{2}$ concentrations at the NOAA/Global Monitoring Laboratory (GML) surface sites}

We used the NOAA/GML measurements of both $\mathrm{CO}_{2}$ and COS at 10 sites located in both hemispheres, listed in Table 4.

The samples have been collected as pair flasks one to five times a month since 2000 and are then analysed in the NOAA/GML's Boulder laboratories with gas chromatography and mass spectrometry detection. The measurements are retained only if the difference between the pair flasks is less than $6.3 \mathrm{ppt}$ for COS. These COS measurements can be downloaded from the ftp site ftp://ftp.cmdl.noaa.gov/hats/ carbonyl_sulfide/ (last access: 19 April 2021). The $\mathrm{CO}_{2}$ atmospheric measurements come from the NOAA's GlobalView Plus Observation Package (ObsPack; Cooperative Global Atmospheric Data Integration Project, 2018).

\subsubsection{Evaluation metrics}

To evaluate and compare the performances of the mechanistic and LRU approaches at different NOAA surface sites, we used the normalised standard deviation (NSD) and the Pearson correlation coefficient $(R)$. NSD is calculated as the ratio between the standard deviation of the simulated concentrations and the observed concentrations at the NOAA surface sites. NSD and $R$ values closer to 1 indicate a better accuracy of the model.

\section{Results}

\subsection{Site-scale COS fluxes, conductances, and LRU}

\subsubsection{COS fluxes}

\section{Diel cycle}

COS assimilation is at a minimum at night (between 20:00 and 04:00 local solar time) for observed and simulated fluxes (Fig. 1a). During night, uptake of modelled COS flux is around $-8 \mathrm{pmol} \mathrm{m}^{-2} \mathrm{~s}^{-1}$ while field observations vary between -5 and $0 \mathrm{pmol} \mathrm{m}^{-2} \mathrm{~s}^{-1}$. In the morning, both simulated and observed uptakes increase. However, while the simulation shows a maximum assimilation of $-38 \mathrm{pmol} \mathrm{m}^{-2} \mathrm{~s}^{-1}$ at noon, the maximum assimilation for observations is reached at 10:00 with a flux of $-49 \mathrm{pmol} \mathrm{m}^{-2} \mathrm{~s}^{-1}$. Observed fluxes thus have a greater daily amplitude than simulated fluxes and are a little ahead of the simulation, but this shift 
Table 4. List of air sampling sites selected for evaluation of $\mathrm{COS}$ and $\mathrm{CO}_{2}$ concentrations.

\begin{tabular}{lllrr}
\hline Site & $\begin{array}{l}\text { Short } \\
\text { name }\end{array}$ & Coordinates & $\begin{array}{r}\text { Elevation } \\
\text { (m a.s.l.) }\end{array}$ & Comment \\
\hline South Pole, Antarctica, United States & SPO & $90.0^{\circ} \mathrm{S}, 24.8^{\circ} \mathrm{W}$ & 2810 & \\
Cape Grim, Australia & CGO & $40.4^{\circ} \mathrm{S}, 144.6^{\circ} \mathrm{W}$ & 164 & inlet is $70 \mathrm{~m}$ aboveground \\
Tutuila, American Samoa & SMO & $14.2^{\circ} \mathrm{S}, 170.6^{\circ} \mathrm{W}$ & 77 & \\
Cape Kumukahi, United States & KUM & $19.5^{\circ} \mathrm{N}, 154.8^{\circ} \mathrm{W}$ & 3 & \\
Mauna Loa, United States & MLO & $19.5^{\circ} \mathrm{N}, 155.6^{\circ} \mathrm{W}$ & 3397 & \\
Niwot Ridge, United States & NWR & $40.0^{\circ} \mathrm{N}, 105.54^{\circ} \mathrm{W}$ & 3475 & \\
Wisconsin, United States & LEF & $45.9^{\circ} \mathrm{N}, 90.3^{\circ} \mathrm{W}$ & 868 & inlet is 396 m aboveground on a tall tower \\
Mace Head, Ireland & MHD & $53.3^{\circ} \mathrm{N}, 9.9^{\circ} \mathrm{W}$ & 18 & \\
Utqiagvik, United States & UTK & $71.3^{\circ} \mathrm{N}, 155.6^{\circ} \mathrm{W}$ & 8 & \\
Alert, Canada & ALT & $82.5^{\circ} \mathrm{N}, 62.3^{\circ} \mathrm{W}$ & 195 & \\
\hline
\end{tabular}

does not seem significant given the large variability of observations, as represented by the 1 standard deviation in Fig. 1a. RMSD for this mean diel cycle is $8.0 \mathrm{pmol} \mathrm{m}^{-2} \mathrm{~s}^{-1}$, and relative RMSD is $35 \%$. The bias is $-1.7 \mathrm{pmol} \mathrm{m}^{-2} \mathrm{~s}^{-1}$, the standard deviations are $17.5 \mathrm{pmol} \mathrm{m}^{-2} \mathrm{~s}^{-1}$ for the observations and $12.8 \mathrm{pmol} \mathrm{m}^{-2} \mathrm{~s}^{-1}$ for the simulated fluxes, and the correlation coefficient is 0.91 . A similar study at the Hyytiälä site over July-September in the year 2015 (Fig. B1a) yields a similar underestimation of the amplitude of the mean diel cycle, with an RMSD of $4.0 \mathrm{pmol} \mathrm{m}^{-2} \mathrm{~s}^{-1}$ and a relative RMSD of $36 \%$; the bias is 2.4 pmol m $\mathrm{m}^{-2} \mathrm{~s}^{-1}$, the standarddeviations are $5.5 \mathrm{pmol} \mathrm{m}^{-2} \mathrm{~s}^{-1}$ for the observations and $2.7 \mathrm{pmol} \mathrm{m}^{-2} \mathrm{~s}^{-1}$ for the simulated fluxes, and the correlation coefficient is 0.93 .

\section{Seasonal cycle}

The simulated weekly seasonal vegetation COS uptake roughly follows the same trend as the observed one $(r=$ 0.53 , Fig. 1b). COS uptake increases in spring when the vegetation growing season starts and decreases in autumn at the end of the forest activity period. Simulated and observed fluxes also take similar values over the 2 years. There are however differences: in 2013 the start of the season is simulated about 2 weeks too late in May instead of late April, and measured fluxes peak in May-June and August-September, while the modelled fluxes peak in July. We notice that the amplitude of observed COS flux variations is larger than the one of modelled fluxes. Kohonen et al. (2020) have quantified the relative uncertainty of weekly-averaged ecosystem COS fluxes at $40 \%$, which is coherent with the large standard deviation computed for field data (Fig. 1b). RMSD for the seasonal cycle is $7.0 \mathrm{pmol} \mathrm{m}^{-2} \mathrm{~s}^{-1}$, and the relative RMSD is $41 \%$. The bias is low $\left(-0.3 \mathrm{pmol} \mathrm{m}^{-2} \mathrm{~s}^{-1}\right)$, and the standard deviations are similar: $6.6 \mathrm{pmol} \mathrm{m}^{-2} \mathrm{~s}^{-1}$ for the observations and $7.7 \mathrm{pmol} \mathrm{m}^{-2} \mathrm{~s}^{-1}$ for the simulated fluxes. At the Hyytiälä site in the year 2015 (Fig. B1b), the RMSD for the seasonal cycle is $2.4 \mathrm{pmol} \mathrm{m}^{-2} \mathrm{~s}^{-1}$, and the relative RMSD is $25 \%$; the bias is low too $\left(0.2 \mathrm{pmol} \mathrm{m}^{-2} \mathrm{~s}^{-1}\right)$ and the standard deviations are also close: $3.6 \mathrm{pmol} \mathrm{m}^{-2} \mathrm{~s}^{-1}$ for the observations and $3.5 \mathrm{pmol} \mathrm{m}^{-2} \mathrm{~s}^{-1}$ for the simulated fluxes. The correlation coefficient is 0.78 .

\section{Nighttime fluxes}

Figure 2 compares mean daytime and nighttime observed and modelled vegetation COS fluxes and the percentage of the daytime to the total flux, computed for each month over 2012 and 2013 at the Harvard Forest site. We selected an arbitrary PAR threshold of $50 \mu \mathrm{mol} \mathrm{m}{ }^{-2} \mathrm{~s}^{-1}$ to split between daytime and nighttime fluxes. We see that the modelled nighttime flux varies across the growing season, with a maximum uptake of $-10 \mathrm{pmol} \mathrm{m}^{-2} \mathrm{~s}^{-1}$ reached in July and a lower absorption in the enclosing colder months. This seasonal variation can be explained by the seasonal change in LAI and the conductance dependency on $T_{\text {air }}$, which increases in summer. The observed nighttime fluxes are of the same magnitude but present an opposite seasonal cycle with lower uptake at the summer peak, albeit variations are within the 1 standard deviation represented in Fig. 1a. The modelled nighttime fluxes account from $22 \%$ of the total COS uptake at the peak of the growing season to $45 \%$ in April at the very beginning. The observed ones exhibit slightly lower values, between $14 \%$ and $37 \%$. At Hyytiälä, the modelled nighttime ratio is also slightly higher (between $30 \%$ and $34 \%$ ) than the observed one (between $20 \%$ and $25 \%$, Fig. B2). These ratios are in line with other studies: Maseyk et al. (2014) reported a ratio of $29 \pm 5 \%$ over a wheat field in Oklahoma, and Sun et al. (2018c) reported one of $23 \%$ for the San Joaquin Freshwater Marsh site in California. The results may vary given the definitions adopted for nighttime and daytime periods.

\subsubsection{Modelled conductances}

To investigate the importance of each conductance in vegetation COS uptake, we compared the three simulated conductances: leaf boundary layer, stomatal, and internal, studying their variability and their drivers at the diel and seasonal scales. The boundary layer conductance to COS is higher 

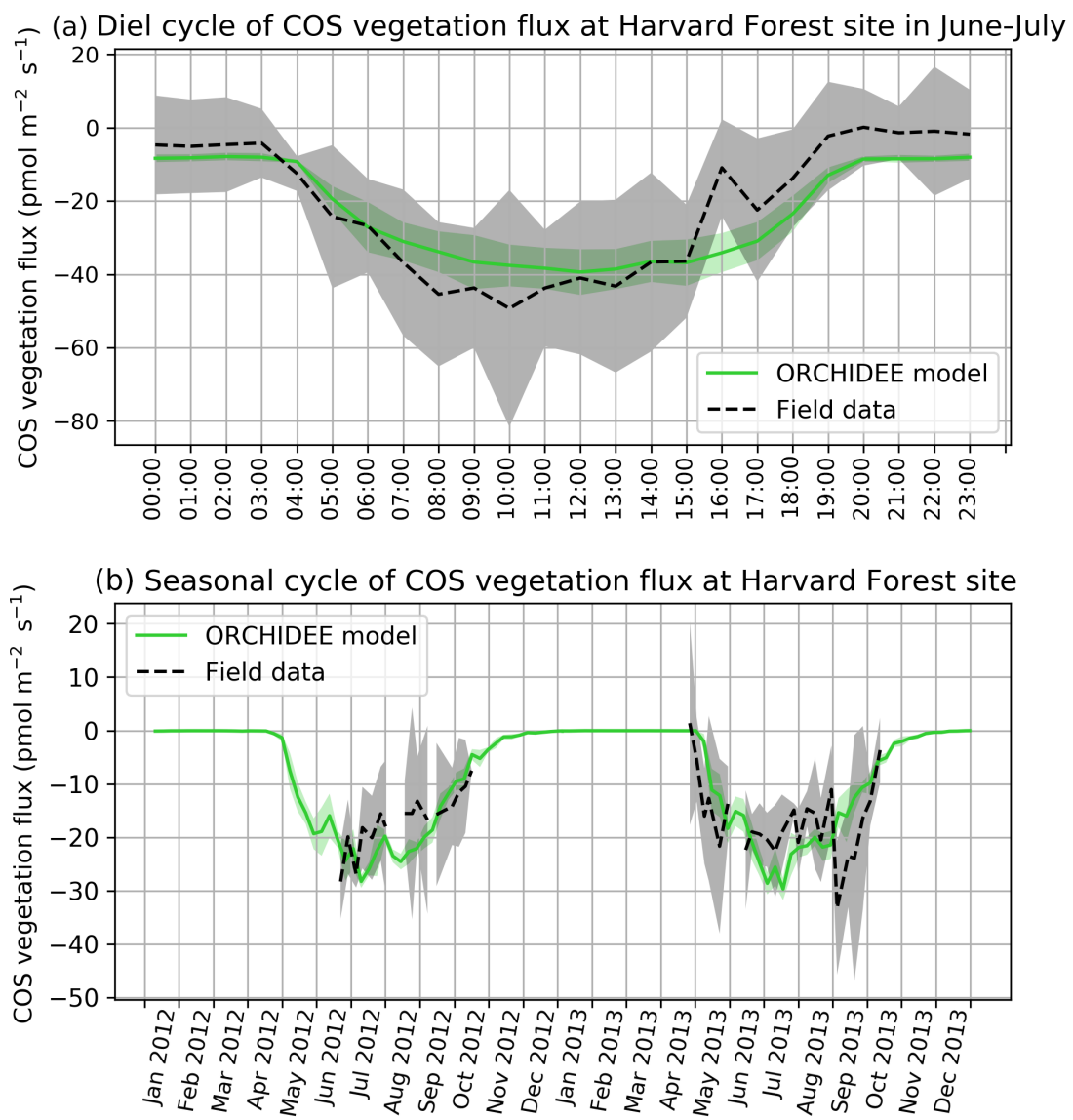

Figure 1. (a) Mean diel cycle of observed vegetation COS flux (Wehr et al., 2017) and modelled COS vegetation flux in June and July 2012 and 2013, at Harvard Forest, using an atmospheric convention where an uptake of COS by the ecosystem is negative. The shaded areas above and below each curve represent 1 standard deviation of the considered hourly values over the June-July period. (b) Mean seasonal cycle of simulated and observed weekly average vegetation COS flux in 2012 and 2013, at Harvard Forest. The shaded areas above and below each curve represent 1 standard deviation of the daily means within the considered week. We imposed the condition of having observations on at least 2 different days to compute the corresponding weekly mean.

than the two other conductances by a median factor larger than 25 (see Table A1 for more detailed statistics). As a high conductance value is equivalent to a low resistance to COS transfer, we focused only on the stomatal $\left(g_{\mathrm{S} \_\mathrm{COS}}\right)$ and internal $\left(g_{\text {I_COS }}\right)$ conductances, which are the two most limiting factors to plant COS uptake.

Figure 3 presents the mean diel cycles of the simulated total, stomatal, and internal conductances for each season, computed over 2012 at Harvard Forest and 2017 at Hyytiälä. For practicality, we shifted the month of December before the month of January of the same year to compute the winter mean. The seasonal variations are similar at both sites. The conductances, as well as the amplitude of their diurnal cycle, increase from winter to summer and decline in autumn. Harvard Forest is predominantly a deciduous forest, and winter values of the conductances are zero at this site as there are no leaves in that season. Hyytiälä on the other hand is an evergreen pine forest, such that daytime stomatal conductance in winter does not become zero. The stomatal conductance peaks between 09:00 and 13:00, depending on site and season, while the internal conductance peaks later in the afternoon. The total conductance is in general limited by the internal conductance. The stomatal conductance is limiting roughly between 18:00 and 06:00 from spring to autumn at Harvard and only in June-July-August roughly between 21:00 and 09:00 at Hyytiälä.

These results are consistent with the results obtained at branch level by Kooijmans et al. (2019), who found that the COS flux was limited by the internal conductance in the early season and later during daytime, while the effect of the stomatal conductance was larger at night. For the Harvard Forest site, Wehr et al. (2017) computed the stomatal conductance using both a water flux method and a COS flux method and obtained a close agreement between two different methods; the mesophyll conductance is modelled using an experimental temperature response, and the biochemical conductance, representing CA activity, is modelled using a simple parameter $\left(0.055 \mathrm{~mol} \mathrm{~m}^{-2} \mathrm{~s}^{-1}\right)$; both scale with LAI to get canopy 
(a) Seasonal cycle of daytime and nighttime coS flux at Harvard Forest site in 2012-2013

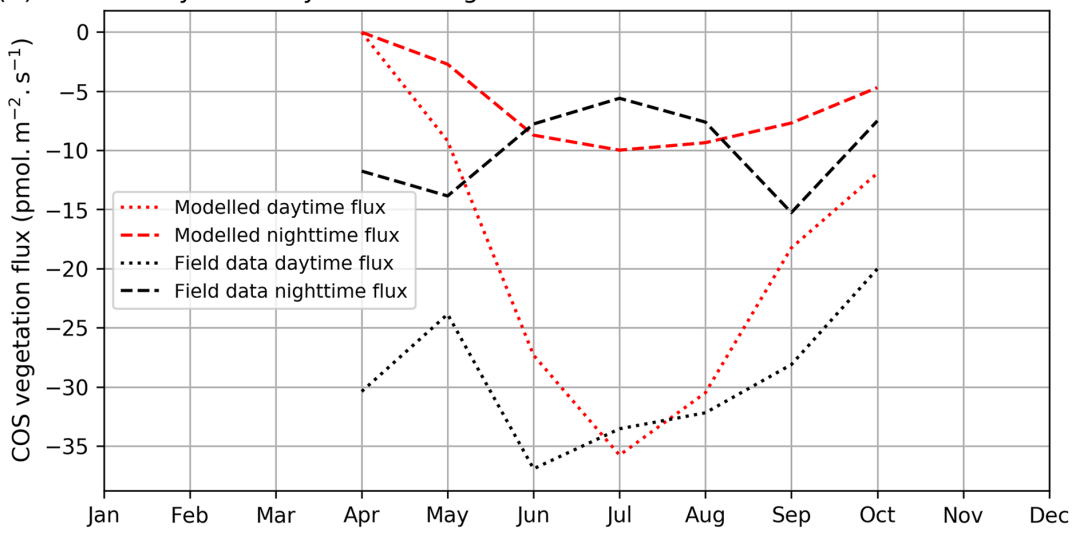

(b) Seasonal cycle of percentage of daytime to total flux at Harvard Forest site in 2012-2013

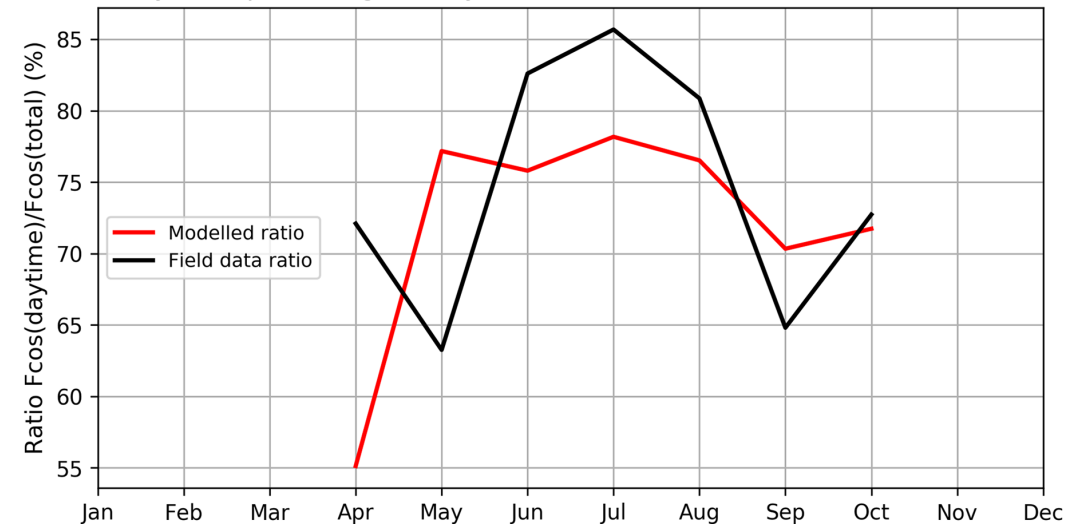

Figure 2. (a) Seasonal cycle of daytime (dotted curve) and nighttime (dashed curve) for observed (black) and modelled (red) vegetation COS fluxes. (b) Seasonal cycle of percentage of the daytime to the total flux (solid curve), at Harvard Forest in 2012-2013.

estimates. Wehr et al. (2017) found similar maximum values around $0.27 \mathrm{~mol} \mathrm{~m}^{-2} \mathrm{~s}^{-1}$ during daytime, from May to October, for the stomatal conductance and for the biochemical conductance (their Fig. 4); adding the slightly larger mesophyll conductance (peaking around $1.0 \mathrm{~mol} \mathrm{~m}^{-2} \mathrm{~s}^{-1}$ ) to the biochemical conductance would thus also lead to a more limiting role of the internal conductance (peaking around $0.21 \mathrm{~mol} \mathrm{~m}^{-2} \mathrm{~s}^{-1}$ ) during daytime, albeit not as strong as for the modelled one (peaking around $0.13 \mathrm{~mol} \mathrm{~m}^{-2} \mathrm{~s}^{-1}$ ); the simulated stomatal conductance exhibits minimum and maximum values similar to the observation-based ones but peaks more sharply in the morning.

To better understand the conductance behaviour, we studied the relative importance of their drivers. These include environmental variables directly or indirectly involved in their modelling: air surface temperature $\left(T_{\text {air }}\right)$, photosynthetically active radiation (PAR), vapour pressure deficit (VPD), and soil moisture (SM), as well as LAI, as leaf-level conductances are summed over LAI layers to provide canopy-level conductances. Partial correlations are computed for all halfhourly values of the variables associated with LRU values between 0 and 8 and are provided in Table A2. We also used half-hourly ORCHIDEE outputs associated with LRU values between 0 and 8 to train random forest models for conductances at the two sites, taking into account the same five predictors. A random predictor was also added to check that the variable importance was correctly estimated. All RF models have an accuracy of at least $96 \%$. Figures B3 and B4 present the relative ranking of the five predictors for the two conductances and the two sites. The ranking is different between the two methods (partial correlation versus RF), but they agree that at both sites the main driver for the internal conductance is air temperature and the main driver for the stomatal conductance is PAR.

As expected, $g_{\text {I_COS }}$ mainly depends on $T_{\text {air }}$. This is explained by the fact that $g_{\mathrm{I}_{-} \mathrm{COS}}$ is proportional to $V_{\max }$, which represents the Rubisco activity for $\mathrm{CO}_{2} ; V_{\max }$ is assumed to be a measure for the mesophyll diffusion and for the CA activity for COS, which are the components of the internal conductance (Berry et al., 2013). $V_{\max }$ depends on $T_{\text {air }}$, considered here to be a proxy of the leaf temperature (Yin and Struik, 2009). This strong link explains why $g_{\text {I_COS }}$ is more limiting in winter, as $T_{\text {air }}$ is low with thus lower enzyme activities, and, as soon as $T_{\text {air }}$ rises in spring, $g_{\text {I }}$ COS becomes less limiting, especially at night. PAR is the most important variable for the stomatal conductance at the two sites. Due to 
(a) Diel cycles of $g_{S_{-} \text {cos }}, g_{I_{\text {_cos }}}$ and $g_{T_{-} \text {cos }}$ for each season at the Harvard site in 2012

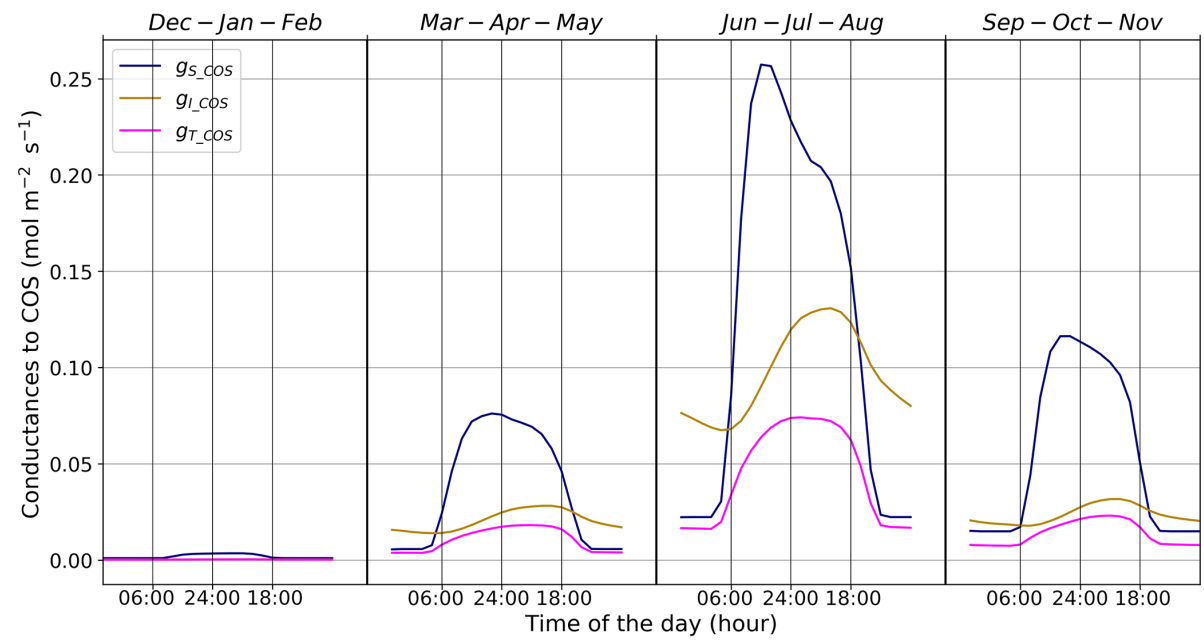

(b) Diel cycles of $g_{S_{-} \text {cos }}, g_{I_{-}} \cos$ and $g_{T_{-} \text {cos }}$ for each season at the Hyytiala site in 2017

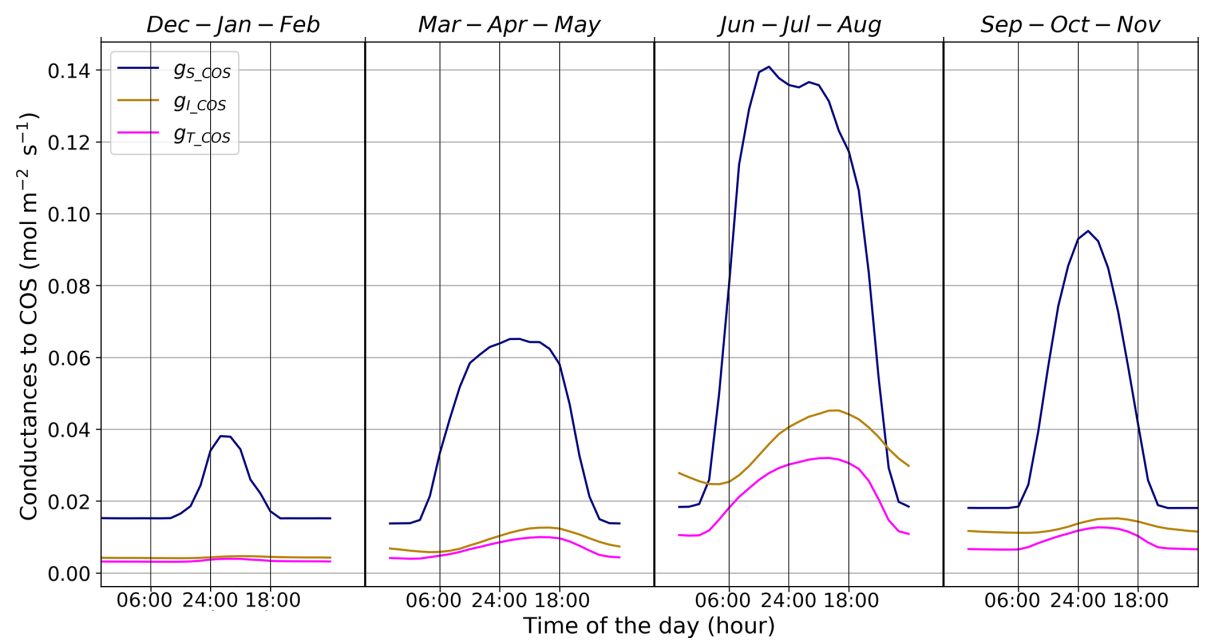

Figure 3. Mean diel cycles of simulated conductances for each season at Harvard Forest in 2012 (a) and Hyytiälä in 2017 (b). The area reference for the units is square metres of ground area.

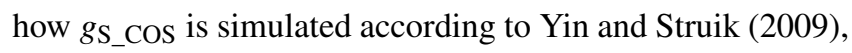
there is a linear relationship with the $\mathrm{CO}_{2}$ assimilation, which depends mainly on PAR.

\subsubsection{LRU variability}

LRU decreases as a function of PAR, as initially observed by Stimler et al. (2010). Kooijmans et al. (2019) made measurements in two branch chambers installed at the top of the canopy in two Scots pine trees in Hyytiälä. They plotted the response of LRU to light, as quantified by PAR. To compare the ORCHIDEE model behaviour to these field data, we determined an LRU using our modelled COS and GPP fluxes, considering a constant atmospheric concentration of $500 \mathrm{ppt}$ for $\mathrm{COS}$ and global yearly values for $\mathrm{CO}_{2}$.

LRU increases with low PAR values for both branch chambers and for the model and converges towards a constant value for high PAR values (Fig. 4). This demonstrates that assuming a constant value for LRU, and not considering an increase in LRU under low-light conditions, will result in erroneous estimation of COS fluxes. The increasing LRU can be explained by the light dependence of the photosynthesis reaction contrary to the CA activity that is light-independent. Consequently, $\mathrm{CO}_{2}$ fluxes tend to zero when PAR decreases while COS is still taken up in the dark, leading in theory to infinite values of LRU. The drop of LRU when PAR increases is however much sharper in the model than in the observations. It is to be noted that here we compare LRU values estimated from measurements at the branch level to modelled LRU estimated at canopy level. We conducted a similar modelling study considering only the top-of-canopy level and the associated COS and GPP fluxes, yielding similar results (not shown). This can be linked to the fact that the version of ORCHIDEE we use considers all the incoming light to be diffuse 


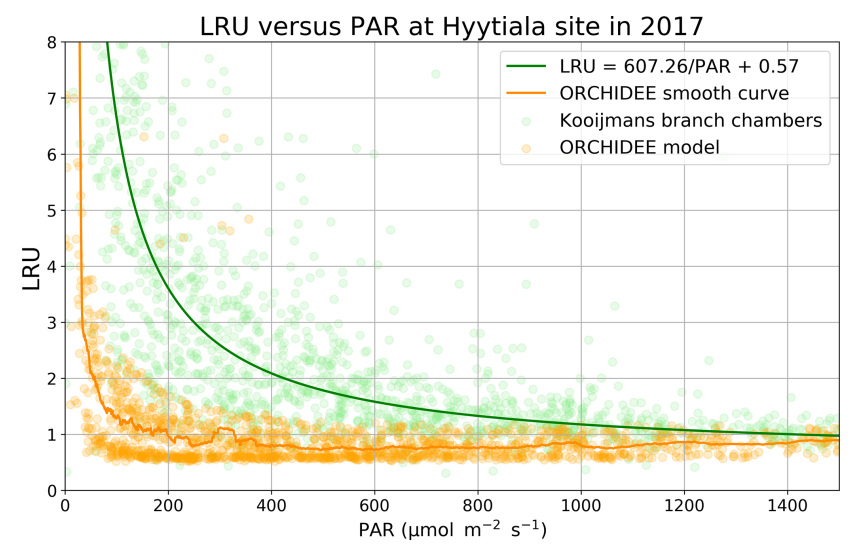

Figure 4. LRU against PAR (Hyytiälä) for ORCHIDEE outputs and measurements (hourly data measured between 18 May and 13 July; Kooijmans et al., 2019). The light green circles represent average LRU values for chambers 1 and 2, and light orange circles represent modelled LRU values. A moving average with a window of 50 points leads to the smooth orange curve for the model. The green line represents the function $\mathrm{LRU}=607.26 / \mathrm{PAR}+0.57$ from Fig. S6 of the Kooijmans et al. (2019) supplement. To focus on LRU behaviour when PAR decreases, we plotted LRU response to PAR for PAR $<1500 \mu \mathrm{mol} \mathrm{m}^{-2} \mathrm{~s}^{-1}$.

and does not distinguish between sun and shaded leaves. We thus have similar LRU values at all canopy levels.

Following the model developed in Seibt et al. (2010, their Eq. 8), the LRU explicitly depends on only two variables: the $g_{\text {S_COS-to- }} g_{\text {I_COS }}$ ratio and the ratio of the $\mathrm{CO}_{2}$ intracellular concentration, $C_{\mathrm{i}}$, to $\left[\mathrm{CO}_{2}\right]_{\mathrm{a}}$ (equally named $C_{\mathrm{a}}$ ) ratio. The modelled daily mean values for the $C_{\mathrm{i}} / C_{\mathrm{a}}$ ratio computed at the two sites vary between 0.68 and 1.00 (Fig. B5). These variations are in agreement with Prentice et al. (2014), who state that the $C_{\mathrm{i}} / C_{\mathrm{a}}$ ratio is pretty stable with only $\pm 30 \%$ variations. These values are in the upper part of the range reported in Seibt et al. (2010, their Table 2); following their Fig. 3, for a given $C_{\mathrm{i}} / C_{\mathrm{a}}$ ratio a larger $g_{\mathrm{S}} \operatorname{Cos}^{- \text {to- }} g_{\mathrm{I} C O S}$ ratio implies a lower LRU, consistent with our results.

We also performed a predictor ranking for LRU, as was done previously with conductances. The predictors rank similarly for the two sites. As shown in Fig. B6, the main factors explaining the variability of the simulated LRU at a halfhourly time step are PAR, $T_{\text {air }}$, and LAI.

\subsection{Global-scale plant COS fluxes and study of LRU values}

\subsubsection{Comparison of plant COS uptake sink estimates}

The mechanistic approach simulated in the ORCHIDEE model gives a plant COS uptake of $-756 \mathrm{Gg} \mathrm{S} \mathrm{yr}^{-1}$ over the 2000-2009 period. COS fluxes are the strongest in South America, Central Africa, and Southeast Asia (Fig. 5), as ex- pected as these regions are also the most productive ones for GPP.

The more recent studies (Montzka et al., 2007; Suntharalingam et al., 2008; Berry et al., 2013; Launois et al., 2015b) show a higher global plant sink than the one initially found by Kettle et al. (2002) (Table 5). Kettle et al. (2002) used an LRU-like approach, based on net primary productivity (NPP) and on the normalised difference vegetation index (NDVI) temporal evolution, and already acknowledged their estimate was assumed to be a lower-bound one. Estimates from plant chambers and atmospheric measurements (Sandoval et al., 2005; Montzka et al., 2007; Campbell et al., 2008) confirmed that the COS plant sink should be 2-fold to 5-fold larger than estimated in Kettle et al. (2002). Suntharalingam et al. (2008) also found a low estimate of $-490 \mathrm{Gg} \mathrm{S} \mathrm{yr}^{-1}$, using 3D modelling of COS atmospheric concentrations, constrained by surface site observations. We note that our estimate is similar to the $-738 \mathrm{Gg} \mathrm{S} \mathrm{yr}^{-1}$ found by Berry et al. (2013), which was implemented in the Simple Biosphere ( $\mathrm{SiB}) 3 \mathrm{LSM}$. The reason for this similarity can be that, on top of using the same mechanistic model for vegetation COS uptake, the leaf photosynthesis and stomatal conductance in both LSMs are derived from the same classical models from Farquhar et al. (1980), Collatz et al. (1992), and Ball et al. (1987).

Launois et al. (2015b) adopted an LRU approach, using constant LRU values for large MODIS vegetation classes, adapted from Seibt et al. (2010). Based on these values and a set of global GPP estimates from three LSMs (ORCHIDEE, LPJ, CLM4), the authors derived the corresponding global vegetation COS uptakes reported in Table 5. The selection of the LSM itself thus introduces an uncertainty on the global vegetation COS uptake of around $40 \%$ in this case.

Applying the LRU values derived from Seibt et al. (2010) (Table 1) to the global GPP simulated in this study leads to the highest plant COS uptake with $-1343.3 \mathrm{Gg} \mathrm{S} \mathrm{yr}^{-1}$. Seibt et al. (2010) report LRU values for different internal conductance limitations. The LRU values that we used here represent a small limitation of internal conductance to the total COS uptake (the ratio of stomatal to internal conductances is 0.1). A smaller global COS uptake can be expected when the LRU values with a more limiting effect of the internal conductance are used. Applying the LRU values derived from Whelan et al. (2018) (Table 1) leads to an intermediate estimate of $-808.3 \mathrm{Gg} \mathrm{S} \mathrm{yr}^{-1}$, which is closer to the global uptake obtained with the mechanistic model. This analysis shows that the choice for certain LRU values introduces an uncertainty on the global vegetation COS uptake (around $70 \%$ in this case) and highlights the importance of deriving accurate PFT-dependent LRU values.

\subsubsection{Dynamics of simulated LRU values}

The PFT distributions of the LRU values, both those computed using Eq. (1) applied to the monthly climatology of mechanistic COS and GPP fluxes over the 2000-2009 pe- 


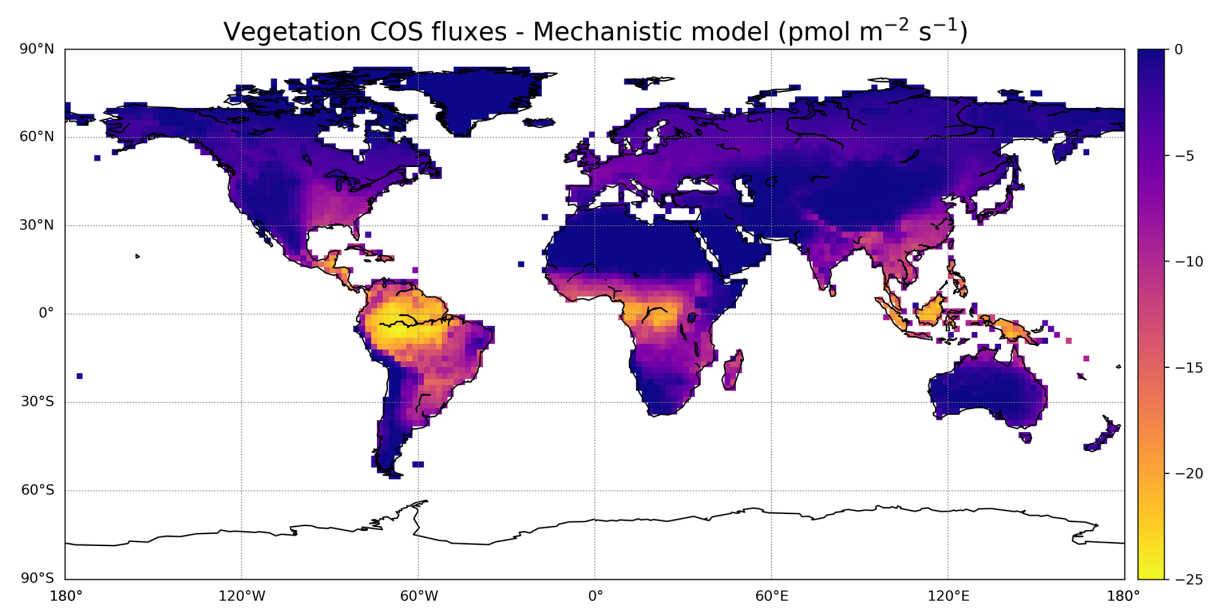

Figure 5. Map of average vegetation COS fluxes over the 2000-2009 period, from the mechanistic model as implemented in ORCHIDEE.

Table 5. Overview of COS plant uptake per year $\left(\mathrm{Gg} \mathrm{S} \mathrm{yr}^{-1}\right)$.

\begin{tabular}{lrrrrrrrr}
\hline & Kettle et al. & Montzka et al. & Suntharalingam & Berry et al. & \multicolumn{2}{c}{ Launois et al. (2015b) } & This study \\
\cline { 5 - 7 } & $(2002)$ & $(2007)$ & et al. (2008) & $(2013)$ & ORC. & LPJ & CLM4 \\
\hline Period study & circa $1990-2000$ & $2000-2005$ & $2001-2005$ & $2002-2005$ & $2006-2009$ & $2000-2009$ \\
Uptake by plants & $-238( \pm 30)$ & -730 to -1500 & $-490(-460$ to -530$)$ & -738 & -1335 & -1069 & -930 & -756 \\
\hline
\end{tabular}

riod (LRU_MonthlyFluxes) and the climatological monthly means computed directly from the original half-hourly values (Monthly_LRU), do not support the idea of a constant PFT-dependent LRU value (Fig. 6).

The distributions are usually not Gaussian; nor are they all unimodal, as is the case for PFT $12 \mathrm{C}_{3}$ agriculture for $\mathrm{C}_{4}$ PFTs (PFT $11 \mathrm{C}_{4}$ grass and PFT $13 \mathrm{C}_{4}$ agriculture) exhibit a large spread. The median values are represented by vertical red bars in Fig. 6 and listed in Table 1. The optimal values (LRU_Opt) obtained by linearly regressing monthly COS fluxes against monthly GPP fluxes multiplied by the ratio of the mean $\mathrm{COS}$ to $\mathrm{CO}_{2}$ concentrations (see Fig. C1) are represented by vertical green bars and also listed in Table 1 . They are usually higher than the median values, with a mean difference of $12.1 \%$. Using either monthly means or yearly means of fluxes gives very similar optimal LRU values, the mean difference being only $-0.2 \%$.

The LRU values from monthly fluxes (LRU_MonthlyFluxes) tend to be lower than the monthly means of the LRU computed at a half-hourly time step (Monthly_LRU). This is visible in Fig. 6 where the blue distributions yield larger LRU values and in the bi-dimensional histogram of LRU_MonthlyFluxes against Monthly_LRU (Fig. C2). The bias is -0.2 and the correlation is 0.67 . This shows that LRU is scale-dependent. The values to be considered should be coherent with their usage. For example, the optimal values we computed are lower than values estimated from measurements, but they are adapted to make the link with atmospheric COS studies.

LRU_Opt values are much smaller than LRU_Seibt values for all PFTs, roughly by a factor of 2 . They are closer to the LRU_Whelan values, being smaller for all $\mathrm{C}_{3}$ PFTs except the tropical broadleaved evergreen forests and higher for $\mathrm{C}_{4}$ PFTs (Table 1). In the LRU_Opt set, the most productive PFTs (tropical forests and $\mathrm{C}_{4}$ crops) have the highest values around 1.7, while the less productive PFTs (boreal forests and grasses) have the lowest values around 0.9 . To the contrary, in the LRU_Seibt set, temperate broadleaved forests have the highest values (3.6) while needleleaf forests have the smallest value around 1.9.

Another way to understand the distribution of LRU values is to look directly at the scatter plots of monthly COS fluxes against GPP fluxes, multiplied by the ratio of $\mathrm{COS}$ to $\mathrm{CO}_{2}$ concentrations (Fig. C1). For most PFTs, it is in fact obvious that the relationship shows non-linear features, disagreeing with the classical linear LRU model. Based on these findings, we fitted a simple exponential model as

$F_{\mathrm{COS}}=a\left(e^{b \mathrm{GPP} \frac{[\mathrm{COS}]_{a}}{\left[\mathrm{CO}_{2}\right]_{\mathrm{a}}}}-1\right)$,

with two parameters $a$ and $b$. However, given the large spread of the data around the model, the Akaike criterion is always favourable to the LRU linear model, so we will not investigate further with this exponential model. More specific research is needed here in order to bridge this data gap. Still, it is important to note that the larger COS fluxes will in gen- 

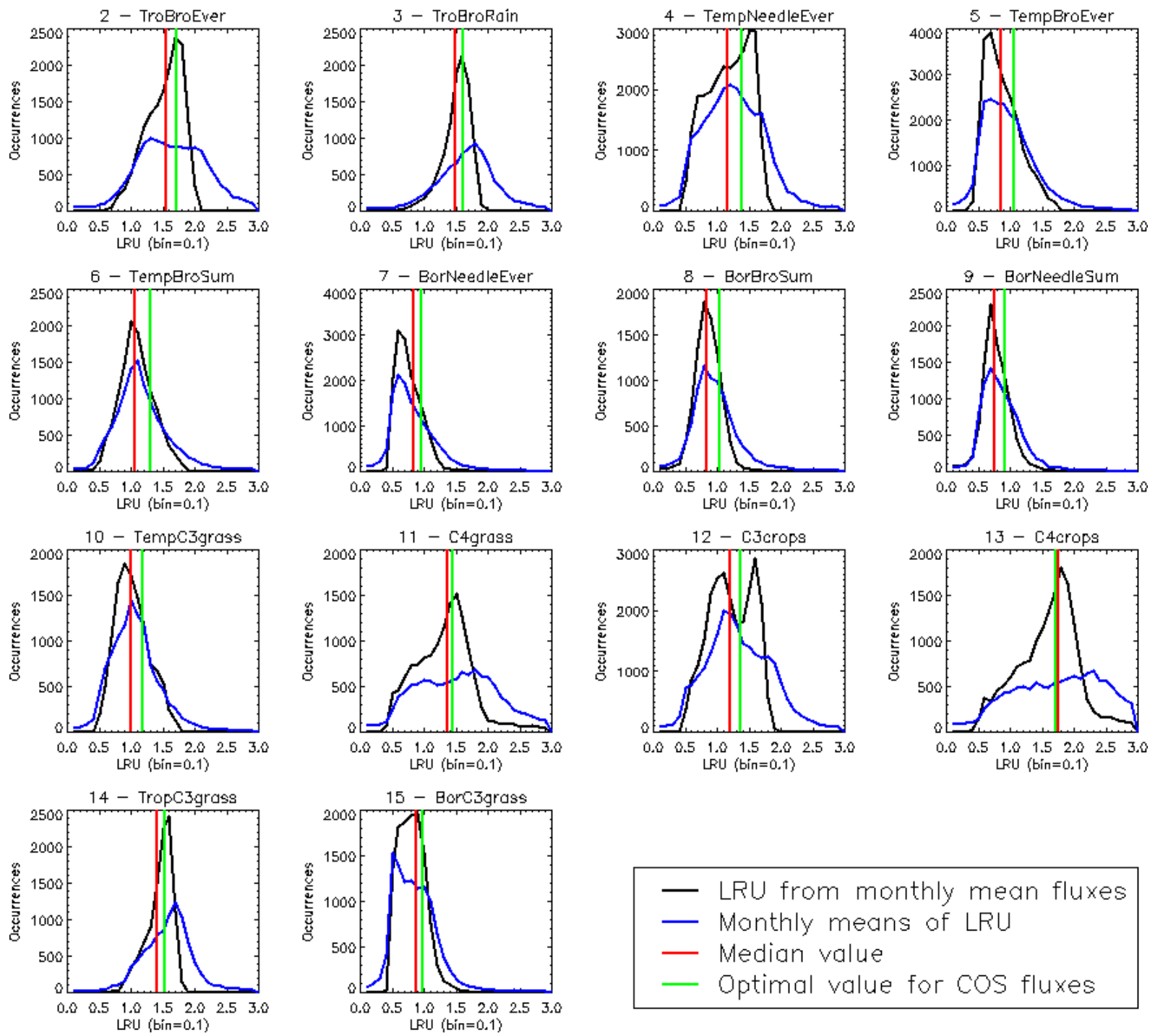

Figure 6. Distributions of the LRU values computed from the mechanistic approach over the 2000-2009 period. Each subplot represents one of the 14 vegetated PFTs used in ORCHIDEE, considering all grid cells where the PFT is present. The $x$ axis represents the LRU value between 0 and 3, with 0.1 bins. The $y$ axis represents the occurrences. For each PFT, the black distribution is computed using a monthly climatology of simulated COS and GPP fluxes (LRU_MonthlyFluxes), the blue distribution is computed using the monthly climatology of LRU values estimated at the original half-hourly time step (Monthly_LRU), the red vertical bar represents the median LRU value for LRU_MonthlyFluxes, and the green vertical bar represents the LRU optimal value that minimises the error between plant COS uptakes estimated at a monthly time step by the mechanistic approach and the LRU approach, for all pixels of the considered PFT (see names and abbreviations in Table 1).

eral be underestimated using a linear LRU approach. It also appears that in certain PFTs $(4,5,7)$ small COS fluxes will be underestimated.

We computed mean annual vegetation COS fluxes using our modelled GPP and this new LRU_Opt set of values and compared them to the mechanistic COS fluxes (Fig. 7a).

The maps of differences between the mechanistic and LRU_Opt-based COS fluxes (Fig. 7b), and relative differences (Fig. 7c), provide evidence for the spatial errors introduced by considering a constant LRU value. The differ- ences are always lower than $4 \mathrm{pmol} \mathrm{m}^{-2} \mathrm{~s}^{-1}$ in absolute values and are mainly positive, with the main exception over the Amazon region where the mechanistic approach shows a larger uptake than the linear LRU approach. The difference between the global estimates of the two approaches is less than $2 \%$; we could still improve the linear regression determining the LRU optimal value by weighting grid-cell fluxes with the corresponding surface of the PFT.

We also compared the mean seasonal cycles of the COS vegetation flux over the 2000-2009 period, for the mecha- 


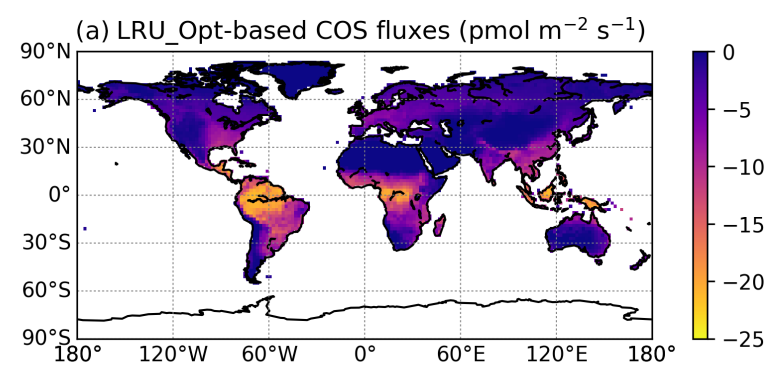

(b) Mechanistic minus LRU Opt-based COS fluxes (pmol m-2 $\mathrm{s}^{-1}$ )
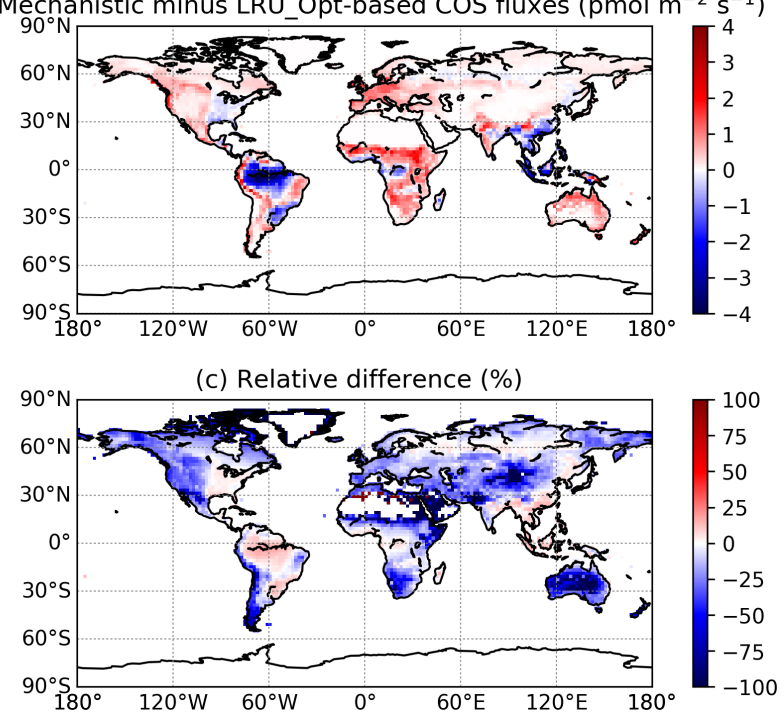

Figure 7. (a) Mean annual vegetation COS fluxes for the 20002009 period fluxes computed using a linear LRU approach with optimal values for each PFT. (b) Differences between mechanistic and LRU-based fluxes. (c) Relative difference (\%).

nistic approach and the LRU_Opt-based approach, for each PFT (Fig. C3). The seasonal cycles are very similar; for PFT $13 \mathrm{C}_{4}$ agriculture, the LRU_Opt-based cycle is slightly in advance compared to the mechanistic cycle.

\subsection{Simulating atmospheric COS concentration at surface stations}

We transported the global $\mathrm{COS}$ and $\mathrm{CO}_{2}$ fluxes (i.e. the ones obtained from the ORCHIDEE model plus the additional components of each cycle, listed in Tables 2 and 3) with the LMDz6 atmospheric transport model as described in Sect. 2.4.2. We analysed COS concentrations derived from simulated COS fluxes obtained with the mechanistic and LRU approaches with regards to observed COS concentrations from the NOAA at a few selected sites.

Figure 8 shows the detrended temporal evolution of $\mathrm{CO}_{2}$ and COS concentrations for the mechanistic and LRU approaches at Utqiagivik (UTK, Alaska) and Mauna Loa (MLO, Hawaii). The MLO site samples air masses coming from all over the Northern Hemisphere (Conway et al., 1994). $\mathrm{CO}_{2}$ seasonal amplitude at UTK reflects the contributions of surface fluxes from high-latitude ecosystems (Peylin et al., 1999), but also from regions further south due to atmospheric transport (Parazoo et al., 2011; Graven et al., 2013). These two stations have been used to detect large-scale changes in ecosystem functioning (Graven et al., 2013; Commane et al., 2017). In spite of their importance, LMDz driven by the ORCHIDEE vegetation fluxes has difficulties in representing their seasonal cycles. For instance, at MLO, the simulated seasonal amplitude of $\mathrm{CO}_{2}$ is overestimated and precedes the observations by 1 month.

For COS, the simulated concentrations match relatively well with the observed seasonal variations and seem to be more in phase with the observations than for $\mathrm{CO}_{2}$. Such a feature could indicate that the phase issues with $\mathrm{CO}_{2}$ are not primarily driven by GPP issues but by the other $\mathrm{CO}_{2}$ flux components. The mechanistic model and its LRU optimal equivalent better reproduce the observed 1-month lag between the $\mathrm{COS}$ and the $\mathrm{CO}_{2}$ simulation at MLO (i.e. the minimum COS lags the one of $\mathrm{CO}_{2}$ ) than the other LRU approaches with values from Whelan et al. (2018) and Seibt et al. (2010). The simulations differ more in the amplitude than in the phase of their seasonal cycles. The mechanistic approach simulates an amplitude lower than the LRU ones. At MLO for example, the lower amplitude of the mechanistic model is in better agreement with the observations. At UTK, its seasonal amplitude is also lower but is now underestimated. The COS concentration at this station from the mechanistic approach varies between +30 and $-50 \mathrm{ppt}$ while it varies between $+50 \mathrm{ppt}(+37)$ and $-71 \mathrm{ppt}(-50)$ for the simulation based on Seibt et al. (2010) (Whelan et al., 2018). This is a direct consequence of lower COS fluxes with the mechanistic model compared to the fluxes based on the Seibt and Whelan LRU approaches. At both the MLO and UTK sites, the difference between the mechanistic model and its LRU optimal equivalent after being transported is lower than $8 \mathrm{ppt}$, within the range of the observation uncertainty.

Table 6 presents the NSDs and Pearson correlation coefficients between simulated and observed COS concentrations for the mechanistic and LRU approaches. We see that the simulation with Seibt et al. (2010) intermediate LRU values overestimates the seasonal standard deviation and has the lowest accuracy for most stations. It is difficult to tell whether the mechanistic model is better than the LRU approach based on Whelan values. While the mechanistic approach captures known features of the temporal dynamics of the COS-to- $\mathrm{CO}_{2}$ flux ratio, it underestimates the simulated concentrations at Alert (ALT, Canada) and Utqiagivik (UTK, United States). It should be noted that, due to other sources of errors (in particular transport and oceanic emissions), the comparison presented here should be taken as a sensitivity study of the COS seasonal cycle to the vegetation scheme rather than a complete validation of one approach. 


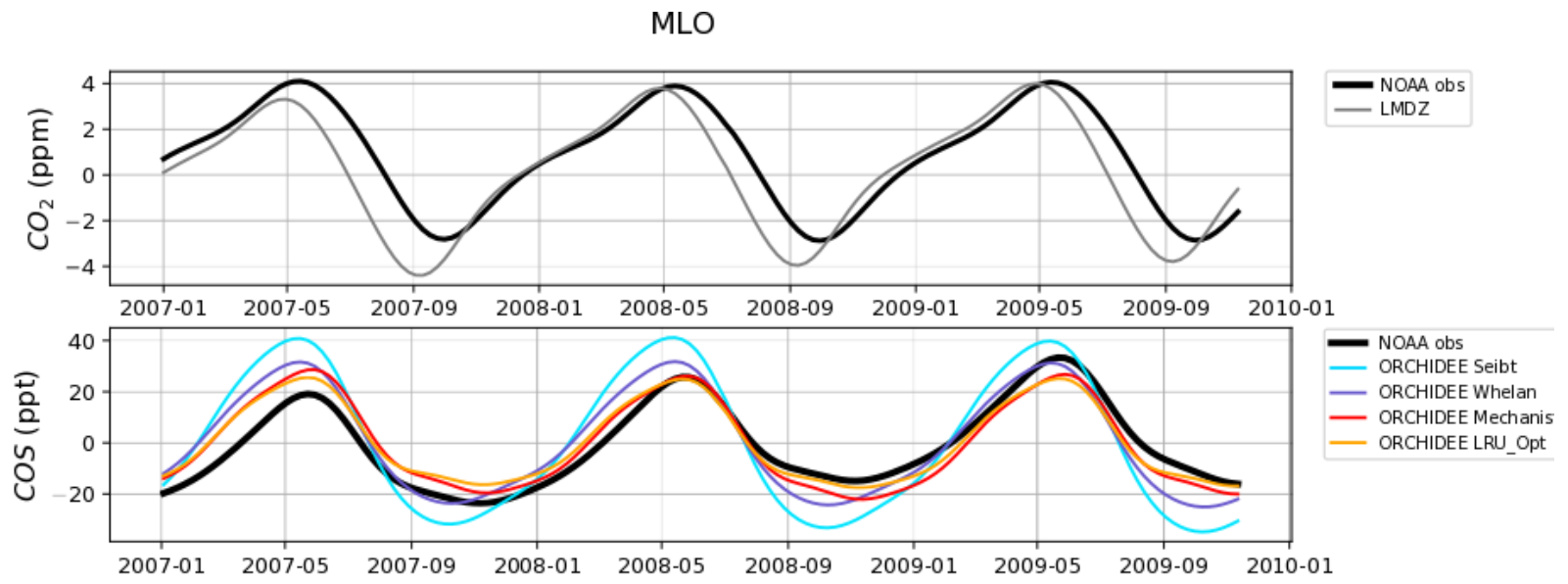

UTK
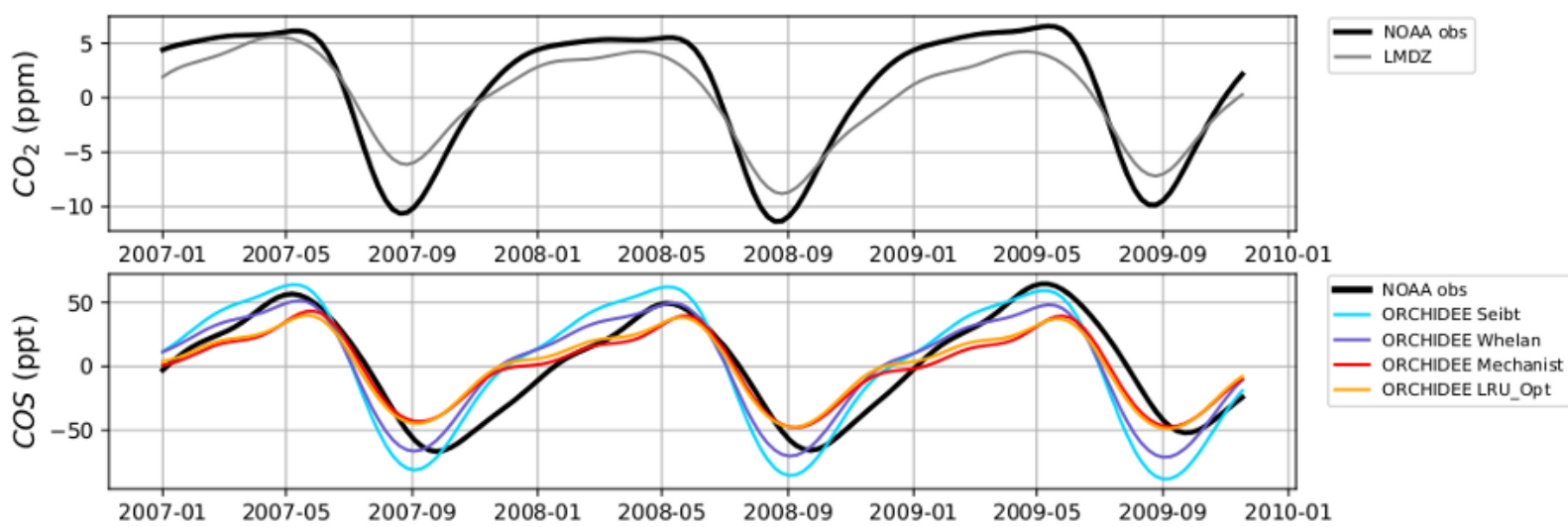

Figure 8. Detrended temporal evolutions of simulated and observed $\mathrm{CO}_{2}$ and $\mathrm{COS}$ concentrations at two selected sites, for the mechanistic (ORCHIDEE Mechanist) and LRU approaches (ORCHIDEE Seibt, ORCHIDEE Whelan, ORCHIDEE LRU_Opt), simulated with LMDz6 transport between 2007 and 2009. The ORCHIDEE LRU_Opt line (orange) corresponds to the concentrations simulated using the optimal LRU values derived from the mechanistic model. Top: Mauna Loa station (MLO, Hawaii); bottom: Utqiagivik station (UTK, Alaska). The curves have been detrended beforehand and filtered to remove the synoptic variability (see Sect. 2.2.4)

Table 6. Normalised standard deviations (NSDs) of the simulated concentrations by the observed concentrations. Within brackets are the Pearson correlation coefficients $(R)$ between simulated and observed COS concentrations for the mechanistic and LRU approaches, calculated between 2004 and 2009 at 10 NOAA stations. For each station, NSD and $R$ closest to 1 are in bold and the farthest ones are in italic. The time series have been detrended beforehand and filtered to remove the synoptic variability (see Sect. 2.2.4).

\begin{tabular}{lllllllllll}
\hline & SPO & CGO & SMO & KUM & MLO & NWR & LEF & MHD & UTK & ALT \\
\hline ORCHIDEE & 1.15 & 0.67 & $\mathbf{0 . 5 8}$ & 1.32 & 1.65 & 2.12 & 2.17 & 1.52 & 1.25 & 1.16 \\
Seibt & $(0.96)$ & $(0.5)$ & $(-0.47)$ & $(0.92)$ & $(0.89)$ & $(0.50)$ & $(0.92)$ & $(\mathbf{0 . 9 6})$ & $(0.90)$ & $(\mathbf{0 . 9 5})$ \\
\hline ORCHIDEE & $\mathbf{1 . 0 0}$ & 0.83 & 0.40 & $\mathbf{1 . 0 3}$ & 1.23 & 1.50 & 1.67 & 1.26 & $\mathbf{1 . 0 0}$ & $\mathbf{0 . 9 2}$ \\
Whelan & $(0.97)$ & $(0.91)$ & $(0.1)$ & $(0.93)$ & $(0.90)$ & $(0.52)$ & $(0.93)$ & $(0.94)$ & $(0.90)$ & $(0.94)$ \\
\hline ORCHIDEE & 1.10 & $\mathbf{1 . 0 1}$ & 0.35 & 0.90 & $\mathbf{1 . 0 5}$ & 1.26 & $\mathbf{1 . 3 4}$ & 1.09 & 0.69 & 0.64 \\
Mechanist & $(0.97)$ & $\mathbf{( 0 . 9 7 )}$ & $\mathbf{( 0 . 4 )}$ & $\mathbf{( 0 . 9 5 )}$ & $\mathbf{( 0 . 9 2}$ & $\mathbf{( 0 . 6 3 )}$ & $(\mathbf{0 . 9 4})$ & $(0.85)$ & $(\mathbf{0 . 9 1})$ & $(\mathbf{0 . 9 5})$ \\
\hline ORCHIDEE & 1.02 & 0.98 & 0.34 & 0.85 & 0.94 & $\mathbf{1 . 2 1}$ & $\mathbf{1 . 3 4}$ & $\mathbf{1 . 0 4}$ & 0.68 & 0.64 \\
LRU_Opt & $\mathbf{( 0 . 9 8}$ & $\mathbf{( 0 . 9 7 )}$ & $(-0.5)$ & $(0.94)$ & $\mathbf{( 0 . 9 2 )}$ & $(0.50)$ & $\mathbf{( 0 . 9 4 )}$ & $(0.88)$ & $(\mathbf{0 . 9 1})$ & $(\mathbf{0 . 9 5})$ \\
\hline
\end{tabular}




\section{Discussion}

\subsection{How can we use COS fluxes and the mechanistic COS model to improve the simulated GPP?}

The mechanistic model links vegetation COS uptake and GPP fluxes through the stomatal conductance model, which includes the minimal conductance as an offset, and the common use of the carboxylation rate of Rubisco, $V_{\max }$, in the internal conductance formulation for COS, and in the Rubiscolimited rate of assimilation for $\mathrm{CO}_{2}$. The downside is the introduction of the somewhat uncertain $\alpha$ parameter that relates the COS internal conductance to $V_{\max }$. Using COS flux measurements to optimise the parameters of the stomatal and internal conductances would thus in principle benefit the simulated GPP. This optimisation may be done based on appropriate data assimilation techniques; for example, Kuppel et al. (2012) optimised key parameters of the ORCHIDEE model related to several processes including photosynthesis (see their Table 2), by assimilating eddy-covariance flux data over multiple sites. The approach relies on a Bayesian framework where a cost function including uncertainties on observations, model, and parameters is minimised (Tarantola, 1987). The results obtained in this study pave the way for a similar approach using COS fluxes to optimise key parameters controlling GPP; they can be used to define an optimal set-up for the a priori errors and the error correlations in a Bayesian framework. We acknowledge however the scarcity of available measurements for the time being, with no samples for most biomes, a few sites with less than 1 year of data, and only Hyytiälä allowing for interannual variability studies.

\subsubsection{First step: improving the mechanistic modelling of vegetation $\operatorname{COS}$ fluxes}

Without any calibration, the chosen mechanistic model was able to reproduce observed vegetation COS fluxes at the Harvard Forest and Hyytiälä sites with relative RMSDs on the order of $40 \%$. Regarding conductances, differences are also seen between the diel cycles of simulated and observationbased conductances from Wehr et al. (2017). Diel variations in atmospheric $[\mathrm{COS}]_{\mathrm{a}}$, not accounted for in our model, cannot explain these differences, as they would only affect $F_{\mathrm{COS}}$ but not the conductances. These discrepancies advocate for the assimilation of COS fluxes to optimise the parameters related to the internal and stomatal conductances. In our modelling framework, the internal conductance is assumed to be the product of $V_{\max }$ by the $\alpha$ parameter. This parameter has been calibrated by Berry et al. (2013) using gas exchange measurements of $\mathrm{COS}$ and $\mathrm{CO}_{2}$ uptake (Stimler et al., 2010, 2012). As this $\alpha$ parameter seems much more uncertain compared to the relatively well-known $V_{\max }$, we should first try to optimise $\alpha$ keeping $V_{\max }$ fixed.

\subsubsection{Exploiting the alternative dominant role between stomatal and internal conductances}

Without being perfect, the mechanistic model could reproduce some expected behaviours, such as the limiting role of the internal conductance in winter and then during daytime in the growing season, in relation to the control of CA activity and mesophyll diffusion by temperature, as also depicted in Kooijmans et al. (2019). Determining the limiting conductances to COS uptake depending on the time of day provides useful information, as it can be used to better target which model parameters to optimise, using data assimilation approaches. Thus, observations made in the morning and early afternoon could be used to better constrain the $\alpha$ parameter when the internal conductance limits COS fluxes, at least as modelled on the $\mathrm{C}_{3}$ species of the two sites, and we could investigate whether the $\alpha$ parameter should be further quantified per PFT rather than simply per photosynthetic pathway. It is to be noted that for $\mathrm{C}_{4}$ species, the internal conductance is larger than for $\mathrm{C}_{3}$ species by a factor of 10 , so that stomatal conductance is limiting, and it could be difficult and useless to try optimising internal conductance using the $\alpha$ parameter. We have to acknowledge the large uncertainty regarding the modelling of the internal conductance. In parallel to optimising the parameters of the internal conductance, an improvement could thus also be to replace it by the two factors it represents, i.e. the mesophyll conductance and CA activity. A model for the mesophyll conductance is already implemented in ORCHIDEE, with a simple parameter depending on temperature through a multiplication by a modified Arrhenius function following Medlyn and al. (2002) and Yin and Struik (2009). The impact of mesophyll conductance on photosynthesis and water use efficiency is now more studied (e.g. Buckley and Warren, 2014), even if its modelling remains challenging too: the temperature response has notably been reported as highly variable between plant species (von Caemmerer and Evans, 2015), which would imply having PFT-dependent parameters. Regarding measurements, ${ }^{13} \mathrm{C}$ discrimination of the isotopic composition of $\mathrm{CO}_{2}$ exchanges allows for an estimation of the mesophyll conductance (Stangl et al., 2019). Concerning CA activity, we could test the simple model using a constant value presented in Wehr et al. (2017). Measuring CA activity can be done at a coarse frequency, using different techniques (Henry, 1991).

\subsubsection{Exploiting nighttime conductances}

Recent studies have shown that nighttime field measurements of stomatal conductances often exhibit larger values than the ones used in models (Caird et al., 2007; Phillips et al., 2010). In the ORCHIDEE model, minimum stomatal conductances to $\mathrm{CO}_{2}, g_{0}$, take two different values: $6.25 \mathrm{mmol} \mathrm{m}^{-2} \mathrm{~s}^{-1}$ for $\mathrm{C}_{3}$ species and $18.75 \mathrm{mmol} \mathrm{m}^{-2} \mathrm{~s}^{-1}$ for $\mathrm{C}_{4}$ species. However, Lombardozzi et al. (2017), using data from literature, 
found that observed nighttime conductances to $\mathrm{CO}_{2}$ range from 0 to $450 \mathrm{mmol} \mathrm{m}^{-2} \mathrm{~s}^{-1}$ with an overall mean value of $78 \mathrm{mmol} \mathrm{m}^{-2} \mathrm{~s}^{-1}$. Moreover, they defined a mean value for each PFT (see Table A3) while the ORCHIDEE model uses one value for all $\mathrm{C}_{3}$ species and another one for all $\mathrm{C}_{4}$ species. Using higher nighttime stomatal conductances in models has the impact of increasing plant transpiration and reducing available soil moisture, which alters water and carbon budgets, especially in semi-arid regions (Lombardozzi et al., 2017). Lower VPD values at night, which could limit the impact of higher nighttime stomatal conductances, follow an increasing trend however (Sadok and Jagadish, 2020). A better representation of these minimal conductances in the model could then improve the constraint of gas exchange between the atmosphere and the terrestrial biosphere. It is to be noted that Barnard and Bauerle (2013) found, based on sensitivity analyses, that $g_{0}$ was the parameter having the largest influence on their modelled transpiration estimates. They also stress that $g_{0}$ should maybe be seen as an asymptotic minimal value, rather than an offset. During nighttime, the stomatal conductance limits COS uptake. In the model, the nocturnal stomatal conductance to $\mathrm{COS}$ is calculated from the above-mentioned minimum stomatal conductance values. For now, the absolute vegetation COS fluxes at night are slightly overestimated compared to observed fluxes (updated Fig. 1a for Harvard and Fig. B1a for Hyytiälä), thus hinting to overestimated nighttime stomatal conductances. Therefore, nighttime observations of COS fluxes could be used to optimise the minimum stomatal conductance values for each PFT.

We thus see that COS fluxes could be used, through standard data assimilation techniques, to optimise the model parameters related to conductances, thus contributing to the improvement of the GPP. However, many more COS flux measurements are needed over a large variety of biomes, first to assert the validity of the mechanistic COS model at global scale and second to be assimilated in order to improve simulated conductances and GPP estimates.

\subsection{The mechanistic versus LRU approach}

The mechanistic model is able to reproduce the hightemporal-frequency LRU variations observed at sites. It is thus legitimate to consider this approach to be more accurate than the classical linear LRU approach that uses a timeconstant LRU value per PFT to estimate COS fluxes from GPP. Furthermore we have shown that computing LRU values using Eq. (1) applied to monthly mean fluxes yields values lower than computing monthly means of high-frequency LRU values (Fig. 6). This may explain why the LRU values we have thus estimated from monthly mean fluxes show generally lower values than the ones derived from measurements, although these cover a large range from 0.7 to 6.2 (Seibt et al., 2010; Whelan et al., 2018). More recently, Spielman et al. (2019) estimated LRU values from ecosys- tem and soil measurements: 0.89 for an agricultural soybean field, 1.02 for a temperate $\mathrm{C}_{3}$ grassland, 2.22 for a temperate beech forest, and 2.27 for a Mediterranean savanna ecosystem; our corresponding PFTs respectively give 1.37 ( $\mathrm{C}_{3}$ crops), 1.18 (Temp $\mathrm{C}_{3}$ grass), 1.31 (TempBroSum), and 1.06 (TempBroEver), with thus higher estimates for herbaceous plants and lower ones for trees. It is difficult to say whether in situ and laboratory measurements are too sparse and not representative enough of the variability of plants and environmental conditions across the globe to have a reasonable confidence in their derived mean or median LRU values, or whether we can use these LRU values to falsify the modelled COS and/or GPP fluxes. We may also add that LRU values derived from measurements performed in leaf chamber measurements, which are well ventilated and thus associated with large leaf boundary layer conductances, may not be representative of the real-world transfer processes, where the boundary layer conductances vary with wind speed, temporally and within canopy depth (Wohlfahrt et al., 2012).

Without any calibration, the mechanistic approach performs similarly to LRU approaches based on monthly mean fluxes, when COS is transported using all known COS fluxes as inputs, and COS concentrations are evaluated at stations of the NOAA network. We now have a much finer representation of the COS fluxes as, at every time step, the model integrates the plant's response to environmental conditions in the calculation of the internal and stomatal conductances, unlike in the LRU approach which uses constant values for each PFT.

In order to quantify the first-order uncertainty on $F_{\mathrm{COS}}$ related to the fact that we have used a constant $[\mathrm{COS}]_{\mathrm{a}}$ in our implementation of the Berry model, we computed an alterna-

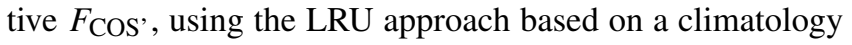
of hemispheric monthly means of COS atmospheric concentrations (Montzka et al., 2007), the optimal LRU we derived in this study (given in Table 1), average yearly values for $\mathrm{CO}_{2}$ atmospheric concentrations, and a climatological seasonal cycle of simulated monthly GPP per PFT. Over the 20002009 period, the mean difference between the mean seasonal COS fluxes computed with this method $\left(F_{\mathrm{COS}}\right.$ ') and the ones simulated with the mechanistic model $\left(F_{\mathrm{COS}}\right)$ amounts to $-7.9 \%$ over the Northern Hemisphere. As expected, the seasonal amplitude of COS fluxes is dampened as $[\mathrm{COS}]_{\mathrm{a}}$ decreases with vegetation growth. We thus have to improve our methodology to consider a varying $[\mathrm{COS}]_{\mathrm{a}}$ as was done in Berry et al. (2013), either inside the ORCHIDEE model or as post-processing. This requires devising some trade-off between the high-frequency time step of ORCHIDEE and the cost of running the transport model. However, it is to be noted that there is no impact on the derived LRU values as the LRU does not depend on the considered $[\mathrm{COS}]_{\mathrm{a}}$, as long as the same one is considered for the computation of the COS fluxes in the mechanistic model (Eq. 3) and for the computation of the LRU (Eq. 1) (i.e. whether fixed or varying monthly). 
However, there is currently a larger uncertainty on other COS fluxes in the global COS budget, which have an important impact on simulated COS concentrations (Ma et al., 2020) and their relative seasonal changes. For example, if we use another estimation of the direct oceanic fluxes (Lennartz et al., 2017), which shows a seasonal cycle whose amplitude is comparable to the one from the vegetation in high latitudes, this results in an overestimated seasonal cycle at all sites, with the mechanistic approach having the most realistic seasonal amplitude (see Appendix D1 and Fig. D1). An additional sensitivity test was performed to assess the impact of indirect oceanic emissions via DMS oxidation on simulated seasonal cycles as the importance of these fluxes in the global COS budget is still debated (Whelan et al., 2018). Whereas the impact on northern sites is negligible, the removal of indirect oceanic emissions via the DMS of Kettle et al. (2002) decreases the seasonal amplitude of southern sites (CGO and SPO) in the same proportion in all experiments (see Appendix D2 and Table D2). Transport errors also add uncertainties on the simulated concentrations, especially at elevated continental sites (Remaud et al., 2018). Plus, given the present discrepancies between the GPP estimates of different land surface models, it can be argued that using a mechanistic model instead of an LRU approach when comparing COS concentrations seems to be of a second-order importance (Campbell et al., 2017; Hilton et al., 2017). We nevertheless note in this study that we found an uncertainty on the global vegetation COS uptake of $40 \%$ when considering three different LSMs (Launois et al., 2015b), to be compared to an uncertainty of $70 \%$ when considering three LRU datasets.

Setting aside the uncertainty for the moment, how could we use atmospheric COS concentrations to constrain GPP? A first optimisation was performed with the ORCHIDEE model in Launois et al. (2015b), who optimised a single scaling parameter applied on the vegetation COS fluxes simulated with the LRU approach, thus equivalent to a scaling factor applied on the GPP or the LRU. They assimilated the atmospheric COS concentrations measured at the NOAA air sampling stations, using the LMDz transport model (Hourdin et al., 2006) and a Bayesian framework as in Kuppel et al. (2012). The optimisation reduced in absolute value the estimated global vegetation COS uptake from -1335 to $-708 \mathrm{Gg} \mathrm{S} \mathrm{yr}^{-1}$, more in line with this work's estimate based on a mechanistic modelling of vegetation COS uptake. A mid-term perspective is to go beyond a single scaling parameter and to optimise a set of ORCHIDEE parameters using both atmospheric $\mathrm{COS}$ and $\mathrm{CO}_{2}$ data. Such an approach has been used in several studies with $\mathrm{CO}_{2}$ data only (e.g. Rayner et al., 2005; Peylin et al., 2016). However, compared to $\mathrm{CO}_{2}$, the spatial coverage of COS surface observations is still too sparse to accurately constrain the GPP and therefore ORCHIDEE parameters (Ma et al., 2020). There is some hope that new satellite retrievals of COS column content, such as with the IASI (Infrared Atmospheric Sounder Interferome- ter) instrument, could have enough accuracy to better constrain the surface fluxes (Serio et al., 2020).

\section{Conclusions and outlooks}

We have implemented the mechanistic model of Berry et al. (2013) inside the ORCHIDEE land surface model for COS uptake by the continental vegetation. Modelled COS fluxes were compared at site scale against measurements at the Harvard temperate deciduous broadleaf forest (USA) and at the Hyytiälä Scots pine forest (Finland), yielding relative RMSDs of around $40 \%$ at both diel and seasonal scales. We found that the mechanistic model yields a lower and thus more limiting internal conductance compared to former works (Seibt et al., 2010; Wehr et al., 2017). The next step is to perform a sensitivity analysis (Morris, 1991; Sobol, 2001) and to optimise the most sensitive parameters related to the modelled fluxes and conductances, to get a better agreement with observations.

Our global estimate of COS uptake by continental vegetation of $-756 \mathrm{Gg} \mathrm{S} \mathrm{yr}^{-1}$ is in the lower range of former studies. An important finding is that the LRU computed from monthly values of the COS and GPP fluxes yields values lower than monthly means of high-frequency LRU values. This has consequences for atmospheric studies where COS concentrations integrate influences from fluxes at large spatial and temporal scales.

Using appropriate LRU values, we transported the monthly mean COS fluxes from the mechanistic and LRU approaches using the LMDz6 model. The evaluation of the modelled COS atmospheric concentrations against observations at stations of the NOAA network yields comparable results for both approaches.

As a general conclusion and for the moment, we can say that the mechanistic model is particularly valuable when studying small timescales or spatial scales using COS fluxes, while for global analyses using COS concentrations, both the mechanistic and LRU approaches give similar results. The fact that the global COS budget has so many components with a large uncertainty (Whelan et al., 2018) limits the use of COS concentrations as a constraint for GPP in land surface models on the global scale, for the present time.

A further development will be to refine the estimation for COS soil fluxes and to implement a mechanistic model for soil COS fluxes inside ORCHIDEE (Ogée et al., 2016; Sun et al., 2015). Having both the vegetation and soil contributions, we will also be able to assimilate ecosystem COS fluxes to optimise COS-related parameters such as $\alpha$ in the internal conductance formulation from the Berry et al. (2013) model for vegetation uptake, and those related to the stomatal conductance (Wehr et al., 2017; Berkelhammer et al., 2020). We will also later look at the complementary constraints on GPP brought by COS and solar-induced fluorescence, another GPP proxy (Bacour et al., 2019; Whelan et al., 2020). 


\section{Appendix A: Additional tables related to conductances}

Table A1. Ratios of modelled boundary conductance to stomatal conductance and internal conductance at the two studied sites, computed over the year 2012 at Harvard Forest and 2017 at Hyytiälä.

\begin{tabular}{lrr|rr}
\hline & \multicolumn{2}{c|}{ Harvard Forest } & \multicolumn{2}{c}{ Hyytiälä } \\
\hline Ratio & $\begin{array}{r}\text { Boundary to } \\
\text { stomatal }\end{array}$ & $\begin{array}{r}\text { Boundary to } \\
\text { internal }\end{array}$ & $\begin{array}{r}\text { Boundary to } \\
\text { stomatal }\end{array}$ & $\begin{array}{r}\text { Boundary to } \\
\text { internal }\end{array}$ \\
\hline Median & 28 & 69 & 46 & 228 \\
\hline Minimum & 9 & 20 & 17 & 48 \\
\hline Maximum & 188 & 1523 & 232 & 9304 \\
\hline
\end{tabular}

Table A2. Partial correlations linking stomatal and internal conductances to photosynthetically active radiation (PAR), air temperature ( $\left.T_{\text {air }}\right)$, vapour pressure deficit (VPD), soil moisture (SM), and leaf area index (LAI), computed at a half-hourly time step over the year 2012 at the Harvard Forest site and 2017 at the Hyytiälä site. For each conductance and each site, the largest partial correlation is in bold.

\begin{tabular}{lllllrl}
\hline Conductance & Site & PAR & $T_{\text {air }}$ & VPD & SM & LAI \\
\hline$g_{\text {S_COS }}$ & Harvard & $\mathbf{0 . 6 6}$ & 0.46 & -0.61 & -0.04 & 0.33 \\
& Hyytiälä & $\mathbf{0 . 5 9}$ & 0.49 & -0.47 & -0.03 & 0.25 \\
\hline \multirow{2}{*}{$g_{\text {I_COS }}$} & Harvard & -0.06 & $\mathbf{0 . 6 8}$ & 0.30 & -0.27 & 0.15 \\
& Hyytiälä & -0.13 & $\mathbf{0 . 7 4}$ & 0.65 & 0.32 & 0.49 \\
\hline
\end{tabular}

Table A3. Minimum stomatal conductance to $\mathrm{CO}_{2}\left(\mathrm{mmol} \mathrm{m}^{-2} \mathrm{~s}^{-1}\right)$ for each PFT in Lombardozzi et al. (2017) and ORCHIDEE. No value is given for $\mathrm{C}_{4}$ crops in Lombardozzi et al. (2017).

\begin{tabular}{lrr}
\hline & $\begin{array}{r}\text { Mean minimum conductance } \\
\text { in Lombardozzi et al. (2017) }\end{array}$ & $\begin{array}{r}\text { Minimum conductance } \\
\text { in ORCHIDEE }\end{array}$ \\
\hline 1 - Bare soil & 0 & 0 \\
2 - Tropical broadleaved evergreen forest & 90.488 & 6.25 \\
$3-$ Tropical broadleaved raingreen forest & 109.744 & 6.25 \\
$4-$ Temperate needleleaf evergreen forest & 16.896 & 6.25 \\
$5-$ Temperate broadleaved evergreen forest & 34.017 & 6.25 \\
$6-$ Temperate broadleaved summergreen forest & 72.637 & 6.25 \\
$7-$ Boreal needleleaf evergreen forest & 8 & 6.25 \\
$8-$ Boreal broadleaved summergreen forest & 50 & 6.25 \\
$9-$ Boreal needleleaf summergreen forest & 29 & 6.25 \\
$10-C_{3}$ grass & 157.988 & 6.25 \\
$11-C_{4}$ grass & 93.933 & 18.75 \\
$12-C_{3}$ agriculture & 60.629 & 6.25 \\
$13-\mathrm{C}_{4}$ agriculture & $\mathrm{x}$ & 18.75 \\
\hline
\end{tabular}


Appendix B: Additional illustrations for results at the site scale
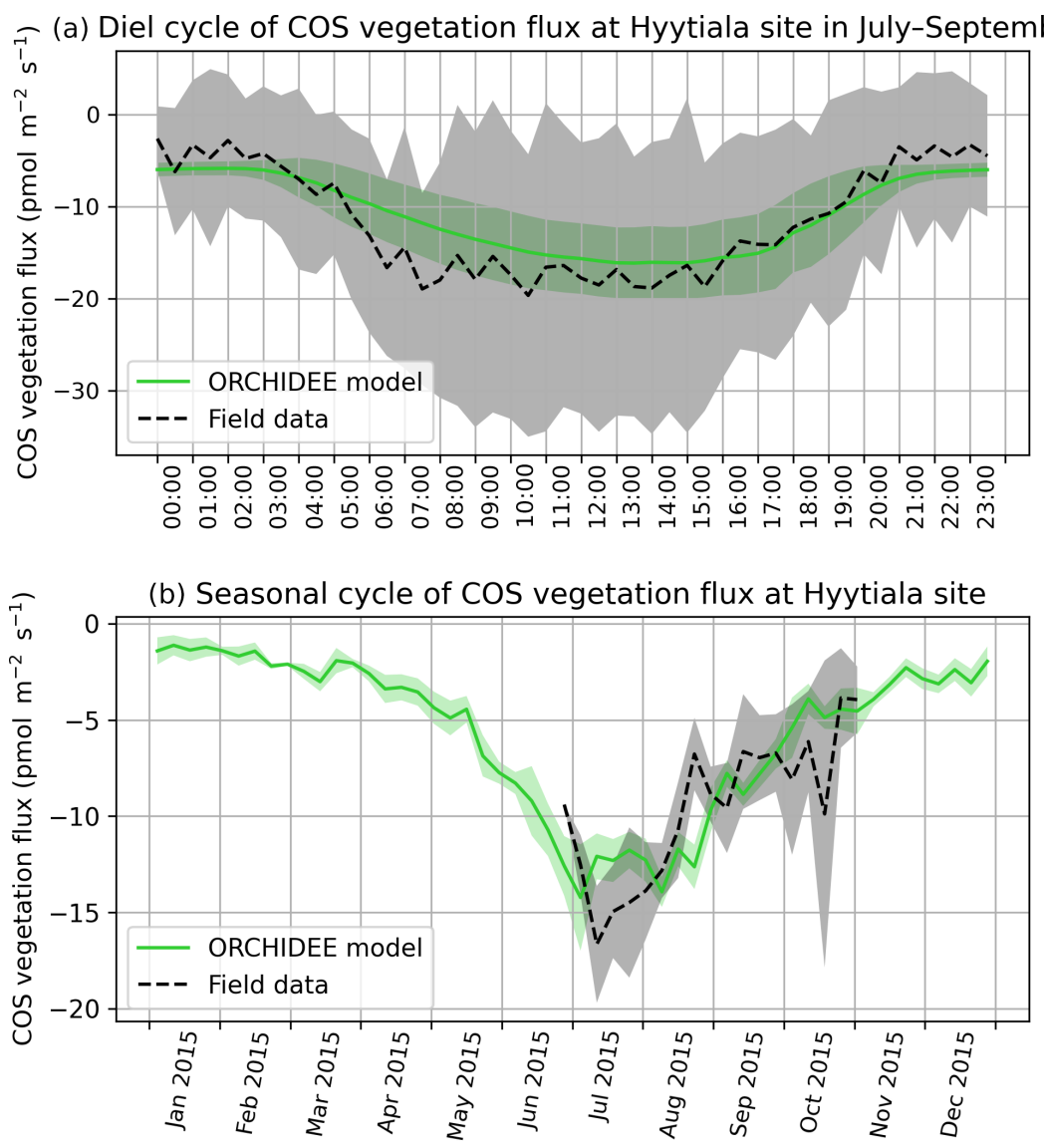

Figure B1. (a) Mean diel cycle of observed vegetation COS flux derived from ecosystem COS flux (Kohonen et al., 2020) and soil COS flux (Sun et al., 2018a), and modelled COS vegetation flux in July-September 2015, at Hyytälä, using an atmospheric convention where an uptake of COS by the ecosystem is negative. The shaded areas above and below each curve represent 1 standard deviation of the considered half-hourly values over the July-September period. (b) Mean seasonal cycle of simulated and observed weekly average vegetation COS flux in 2015, at Hyytälä. The shaded areas above and below each curve represent 1 standard deviation of the daily means within the considered week. 
(a) Seasonal cycle of daytime and nighttime COS flux at the Hyytiälä site in 2015

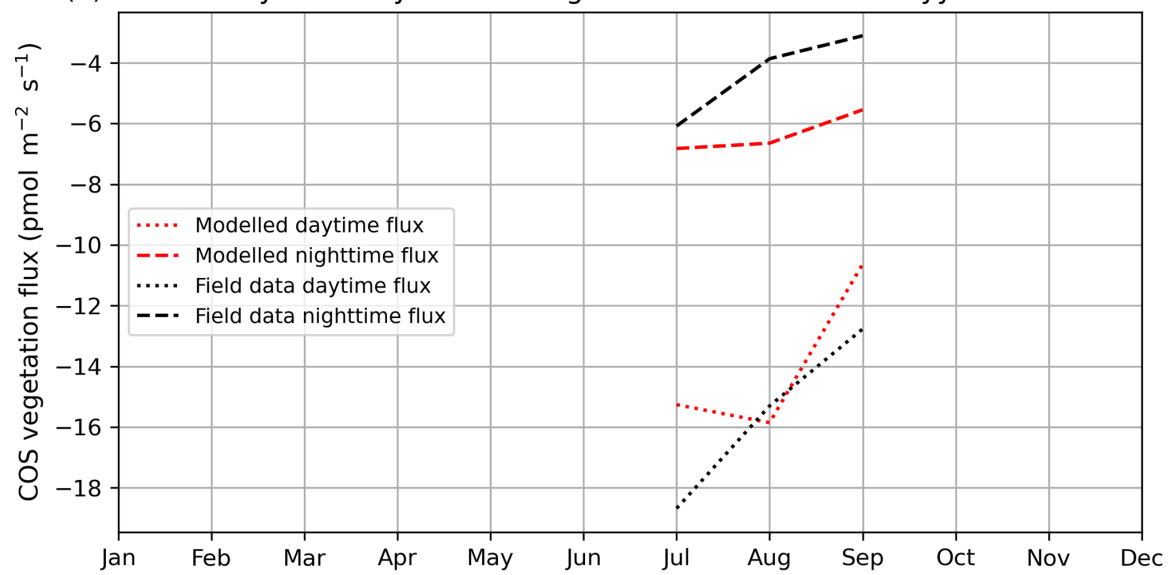

(b) Seasonal cycle of percentage of daytime to total flux at the Hyytiälä site in 2015

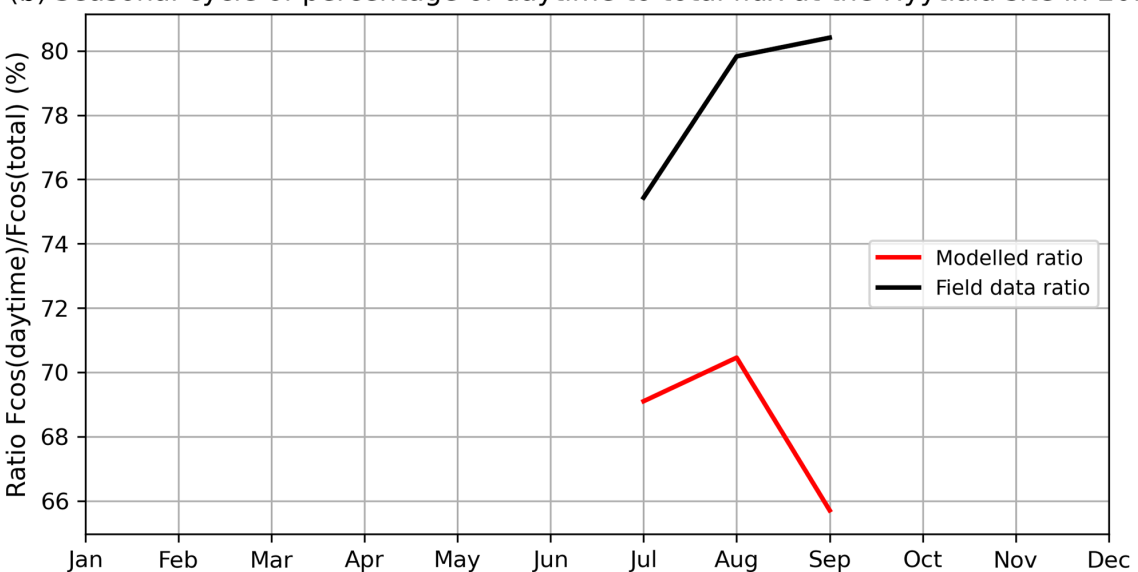

Figure B2. (a) Seasonal cycle of daytime (dotted curve) and nighttime (dashed curve) for observed (black) and modelled (red) vegetation COS fluxes. (b) Seasonal cycle of percentage of the daytime to the total flux (solid curve), at the Hyytiälä site in 2015.
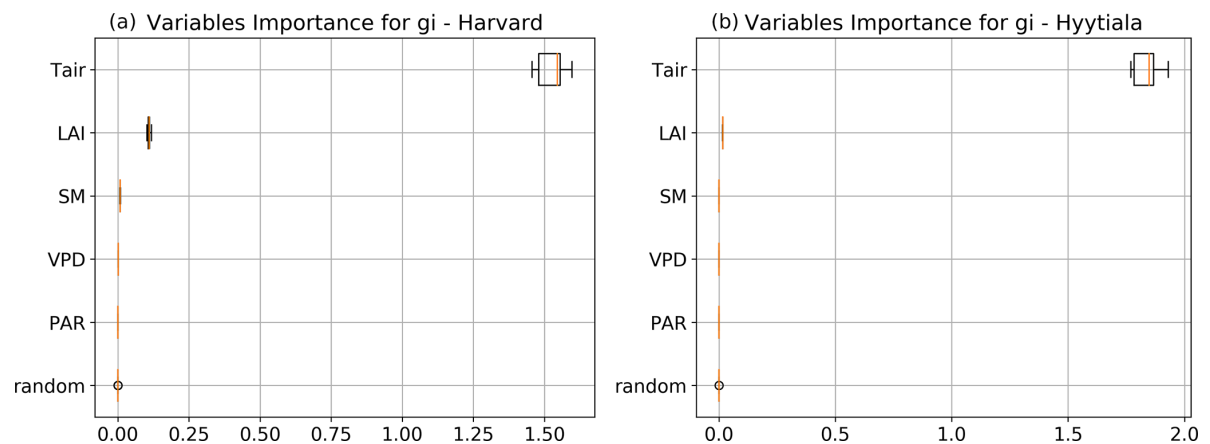

Figure B3. Variables' importance computed using random forests for the internal conductance (gi) at the Harvard Forest site in 2012 (left) and at the Hyytiälä site in 2017 (right). The considered predictors are air temperature ( $T_{\text {air }}$ ), leaf area index (LAI), soil moisture (SM), vapour pressure deficit (VPD), and photosynthetically active radiation (PAR). A random predictor is added to prevent over-fitting. 
(a) Variables Importance for gs - Harvard

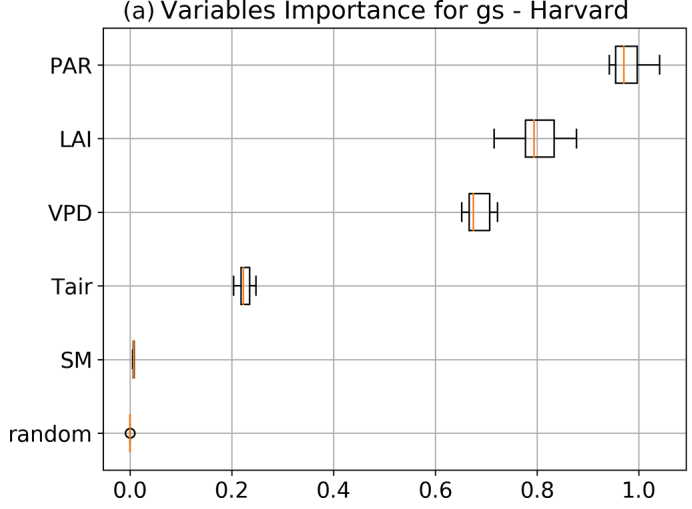

(b) Variables Importance for gs - Hyytiala

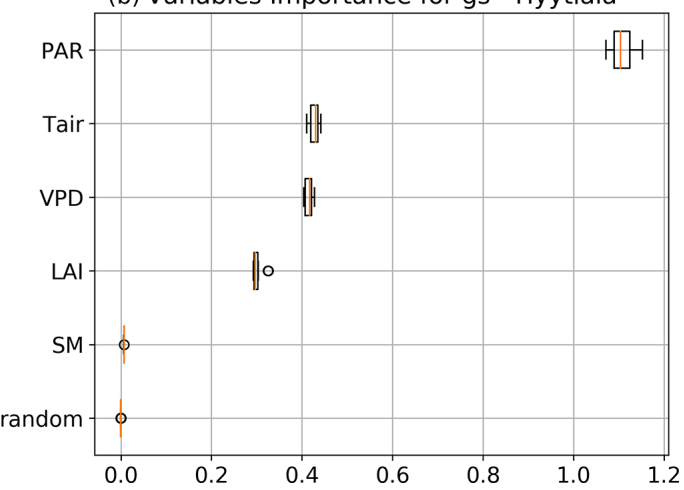

Figure B4. Same as B3 for the stomatal conductance (gs).

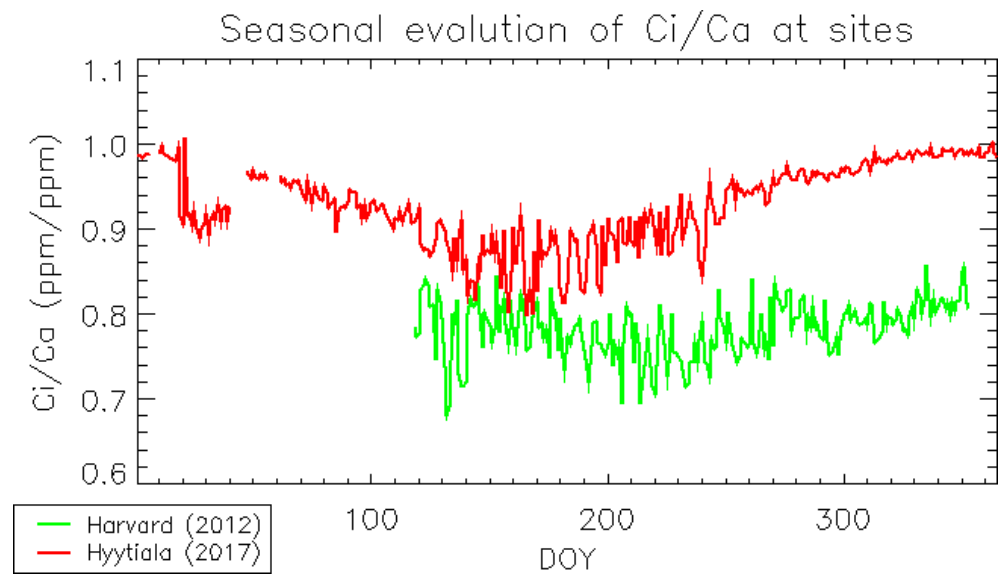

Figure B5. Seasonal evolution of the simulated $C_{\mathrm{i}}$-to- $C_{\mathrm{a}}$ ratio at the Harvard Forest site in 2012 (green curve) and the Hyytiälä site in 2017 (red curve).

(a) Variables Importance for LRU - Harvard

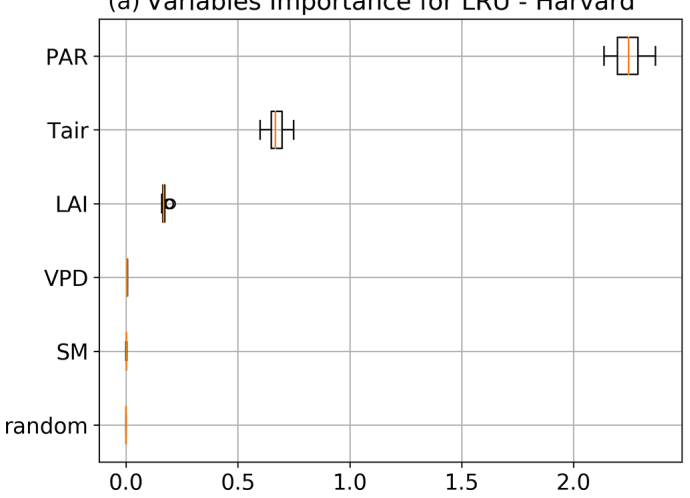

(b) Variables Importance for LRU - Hyytiala

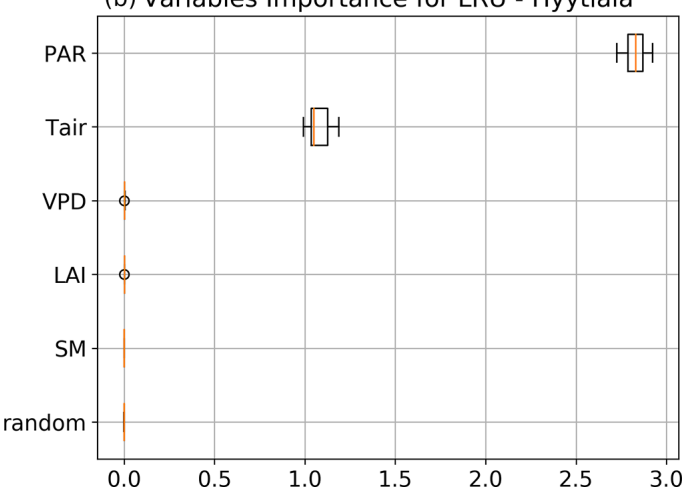

Figure B6. Same as B3 for the leaf relative uptake (LRU). 
Appendix C: Additional illustrations for results at the global scale
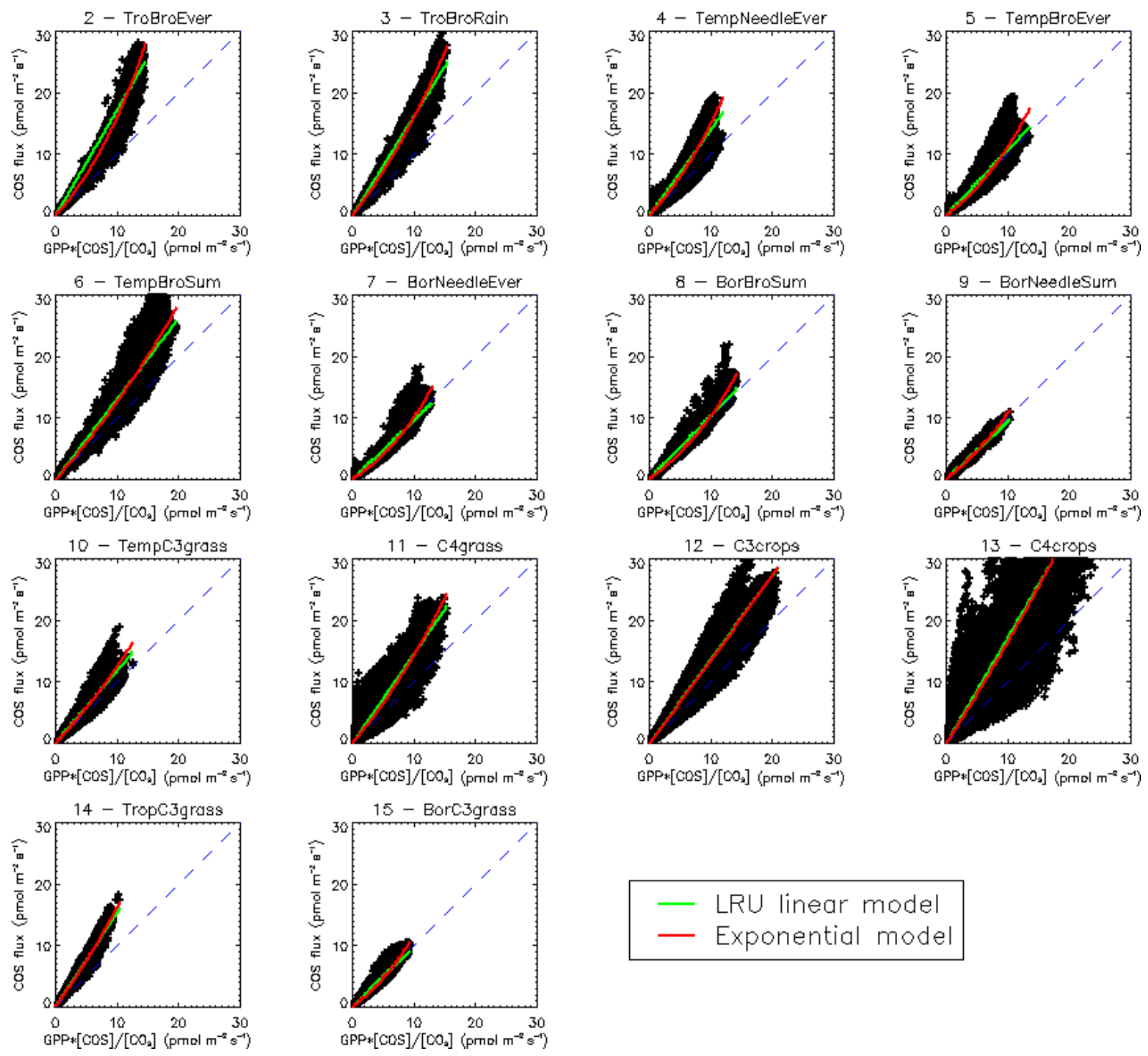

Figure C1. Scatterplots of COS fluxes against GPP multiplied by the ratio of COS to CO2 concentrations, using a climatology of monthly fluxes over the 2000-2009 period and yearly global averages for $\mathrm{CO}_{2}$ concentrations and a fixed value of 500 ppt for the COS concentration. Each subplot represents one of the 14 vegetated PFTs used in ORCHIDEE. The LRU model in green represents the linear regression, while the exponential model (see text) is represented in red. The blue dashed lines show the $1: 1$ line. 


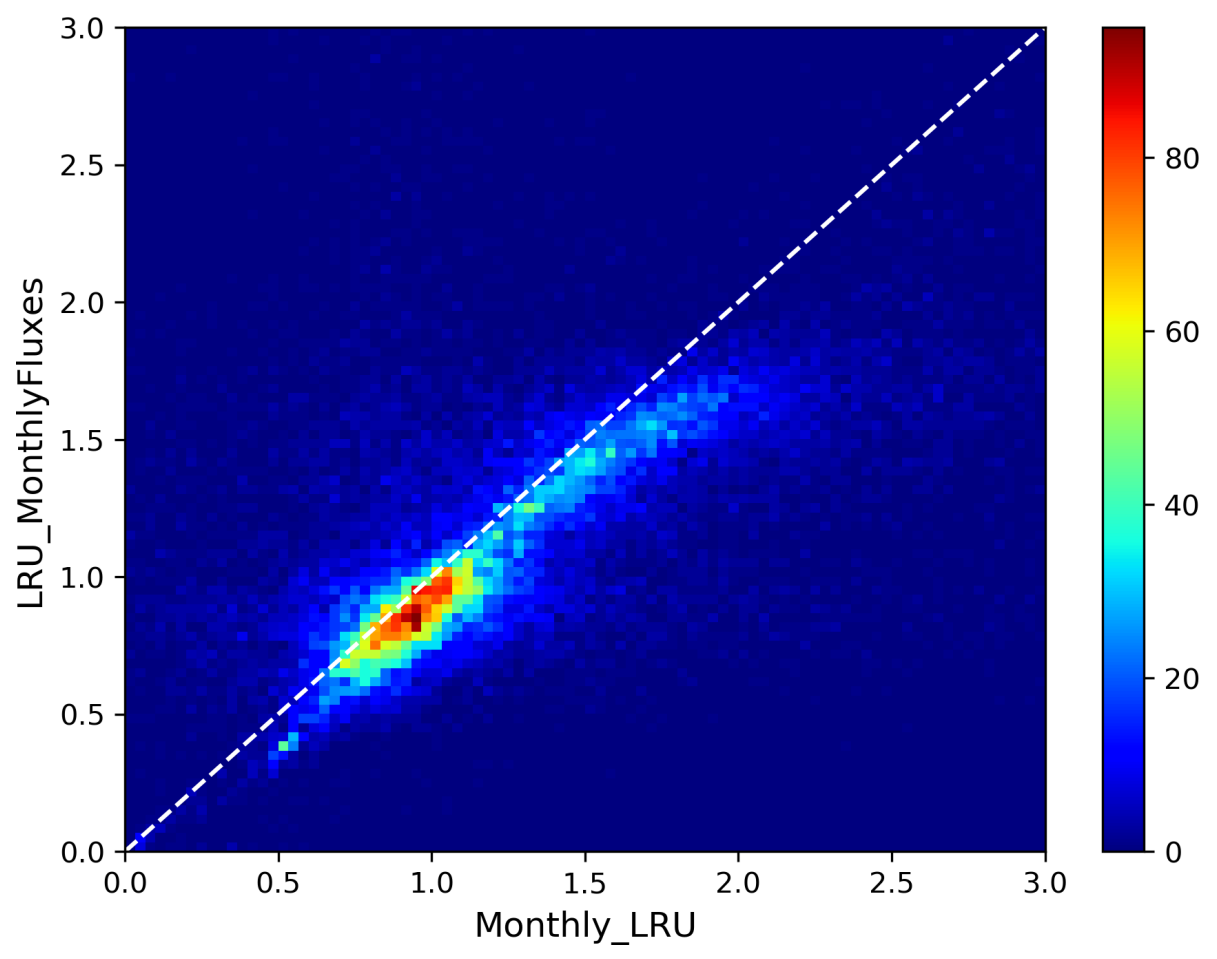

Figure C2. Bi-dimensional histogram of LRU values computed from a climatology of monthly mean fluxes (LRU_MonthlyFluxes) against a climatology of monthly means of LRU computed from original half-hourly values (Monthly_LRU). The colour bar indicates the number of occurrences per bin of $0.1 \times 0.1$ size. The white dashed line represents the first bisector. 

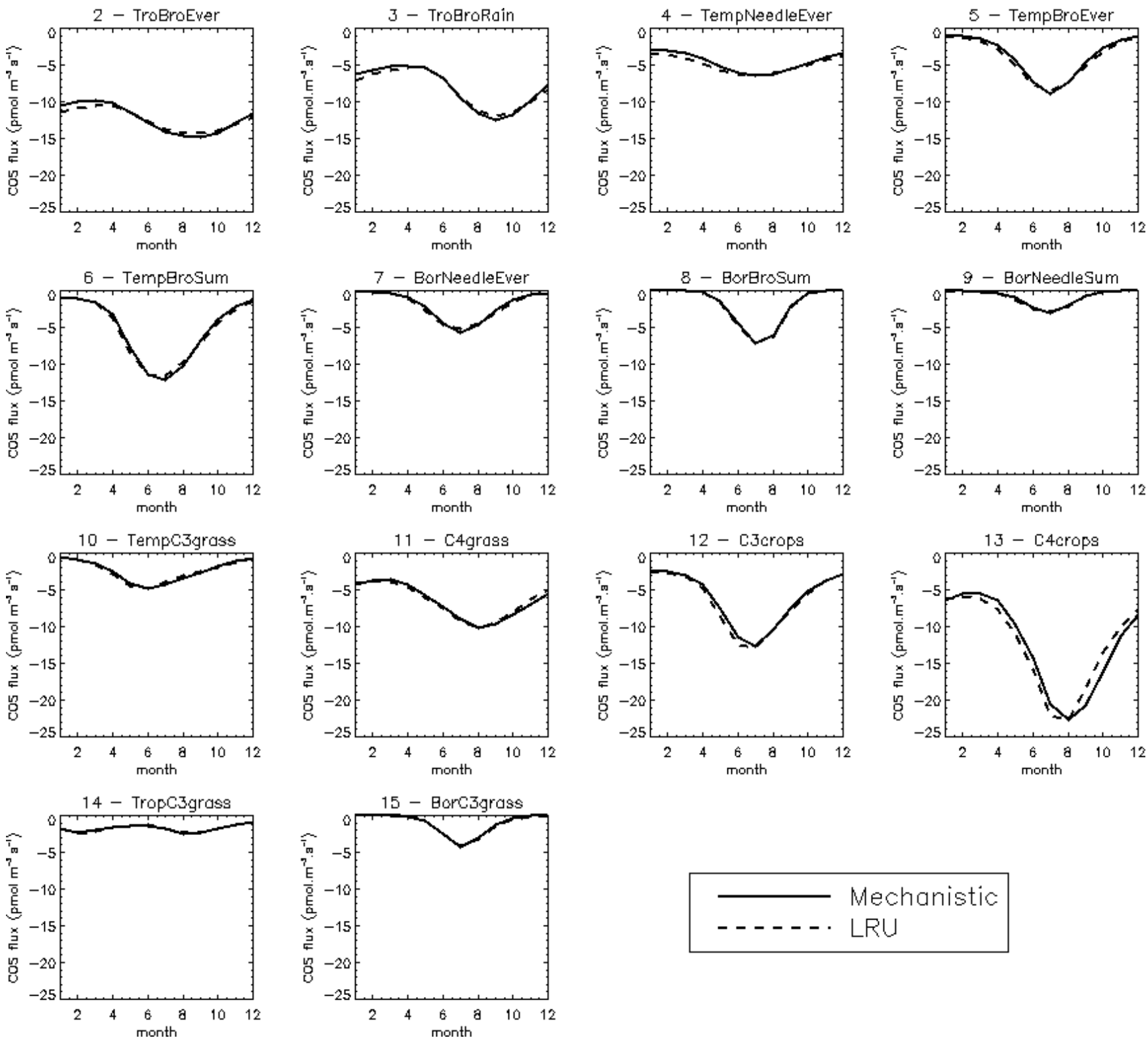

Figure C3. Mean seasonal cycle (monthly means) of COS for each PFT over the Northern Hemisphere for the 2000-2009 period. The solid line represents the mechanistic model, while the dashed line represents the optimal LRU approach. 
Appendix D: Sensitivity tests for the modelling of atmospheric COS concentrations

\section{D1 Simulating COS atmospheric concentration at stations: impact of the oceanic emissions}

We performed the same experiment as in Sect. 3.4, except that the oceanic fluxes (direct and indirect) here are from Lennartz et al. (2017). In our case, the oceanic emissions (in particular direct oceanic emissions) have more impact than the LRU on the seasonality at surface sites from the NOAA network. 
SPO
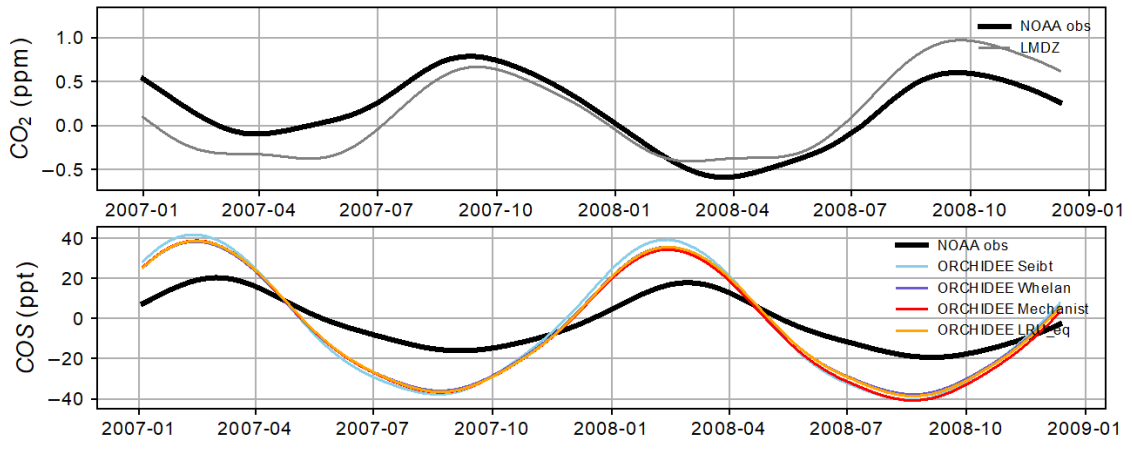

MLO
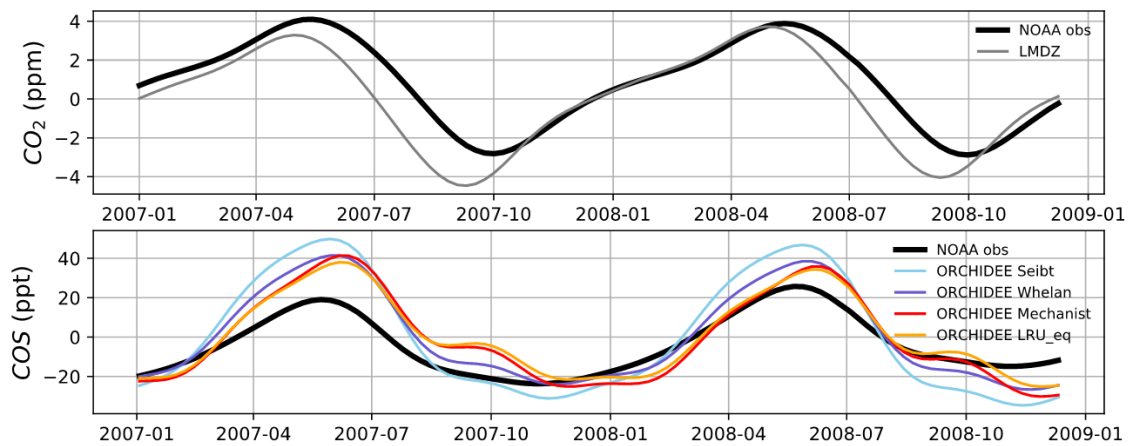

UTK
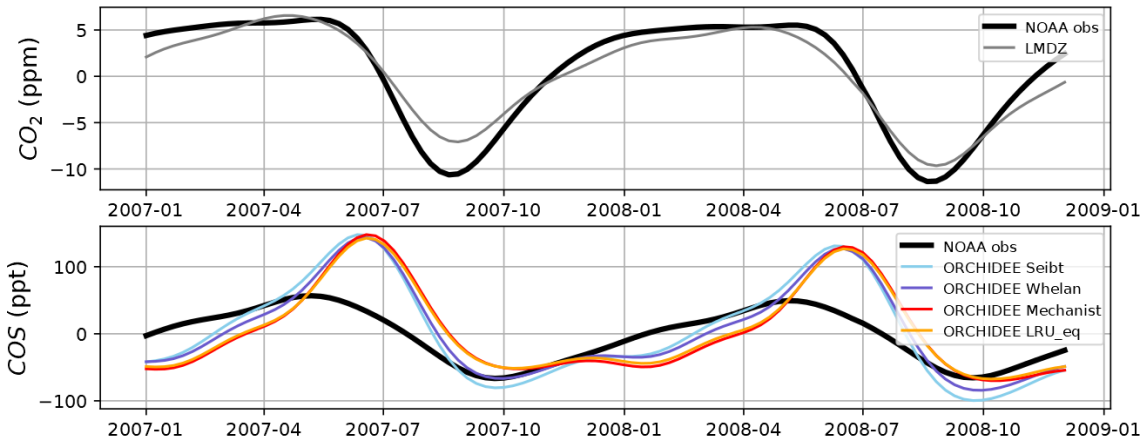

ALT
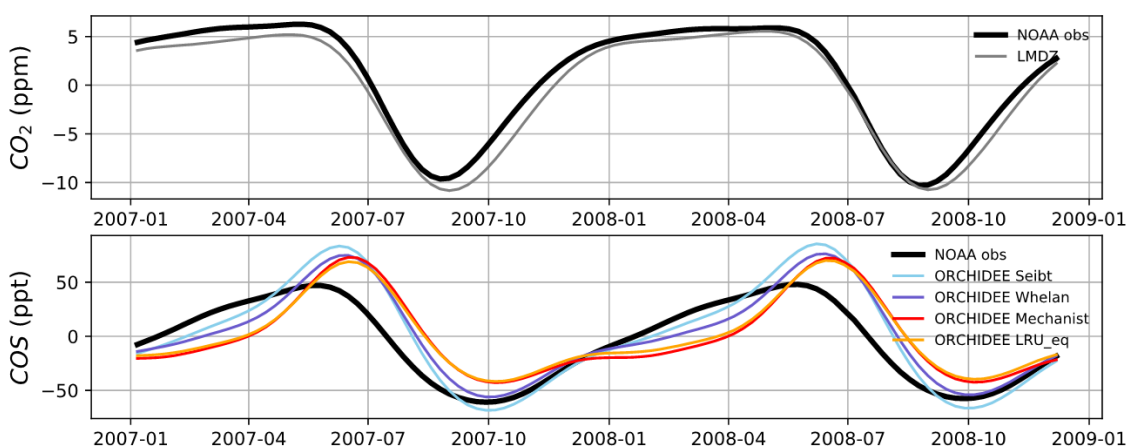

Figure D1. Detrended temporal evolutions of simulated and observed $\mathrm{CO}_{2}$ and $\mathrm{COS}$ concentrations at four selected sites, for the mechanistic (ORCHIDEE Mechanist) and LRU approaches (ORCHIDEE Seibt, ORCHIDEE Whelan, ORCHIDEE LRU_Opt), simulated with LMDz6 transport between 2007 and 2009. The ORCHIDEE LRU_Opt line (orange) corresponds to the concentrations simulated using the optimal LRU values derived from the mechanistic model. The curves have been detrended beforehand and filtered to remove the synoptic variability (see Sect. 2.2.4). 
Table D1. Prescribed COS surface fluxes used as model input. Mean magnitudes of different types of fluxes are given for the period 20002009.

\begin{tabular}{|c|c|c|c|}
\hline Type of COS flux & Temporal resolution & Total $\left(\mathrm{Gg} \mathrm{S} \mathrm{yr}^{-1}\right)$ & Data source \\
\hline Anthropogenic & Monthly, interannual & 337.3 & Zumkehr et al. (2018) \\
\hline Biomass burning & Monthly, interannual & 56.3 & Stinecipher et al. (2019) \\
\hline Soil & Monthly, climatological & -409.0 & Launois et al. (2015b) \\
\hline Ocean & Monthly, climatological & 344.0 & Lennartz et al. (2017) \\
\hline Vegetation uptake & Monthly, interannual & & $\begin{array}{l}\text { This work, including mechanistic } \\
\text { and LRU approaches (Seibt et al., } \\
\text { 2010; } \\
\text { Whelan et al., 2018) }\end{array}$ \\
\hline
\end{tabular}




\section{D2 DMS sensitivity study}

We further tested the impact of the indirect COS fluxes through DMS on the simulated concentrations at NOAA sites. To do that, we compared the atmospheric concentrations given with and without prescribing indirect oceanic fluxes through DMS using the Launois et al. (2015a) oceanic fluxes. In our case, the removal of the DMS oceanic emissions decreases the seasonal amplitude at SPO and CGO but has very few impacts at other sites. We also performed the same experiment using the Lennartz et al. (2017) fluxes and reported no impact of DMS indirect fluxes on simulated concentrations at NOAA sites. 
Table D2. Normalised standard deviations (NSDs) of the simulated concentrations by the observed concentrations. Within brackets are the Pearson correlation coefficients $(R)$ between simulated and observed COS concentrations for the mechanistic approach including the DMS or not, calculated between 2004 and 2009 at 10 NOAA stations.

\begin{tabular}{|c|c|c|c|c|c|c|c|c|c|c|}
\hline & SPO & CGO & SMO & KUM & MLO & NWR & LEF & MHD & UTK & ALT \\
\hline $\begin{array}{l}\text { ORCHIDEE } \\
\text { Mechanist } \\
\text { (DMS) }\end{array}$ & $\begin{array}{l}1.10 \\
(0.97)\end{array}$ & $\begin{array}{l}1.01 \\
(0.97)\end{array}$ & $\begin{array}{l}0.35 \\
(0.4)\end{array}$ & $\begin{array}{l}0.90 \\
(0.95)\end{array}$ & $\begin{array}{l}1.05 \\
(0.92)\end{array}$ & $\begin{array}{l}1.26 \\
(0.63)\end{array}$ & $\begin{array}{l}1.34 \\
(0.94)\end{array}$ & $\begin{array}{l}1.09 \\
(0.85)\end{array}$ & $\begin{array}{l}0.69 \\
(0.91)\end{array}$ & $\begin{array}{l}0.64 \\
(0.96)\end{array}$ \\
\hline $\begin{array}{l}\text { ORCHIDEE } \\
\text { Mechanist } \\
\text { (without DMS) }\end{array}$ & $\begin{array}{l}0.74 \\
(0.91)\end{array}$ & $\begin{array}{l}0.53 \\
(0.94)\end{array}$ & $\begin{array}{l}0.38 \\
(0.20)\end{array}$ & $\begin{array}{l}0.90 \\
(0.95)\end{array}$ & $\begin{array}{l}1.04 \\
(0.91)\end{array}$ & $\begin{array}{l}1.31 \\
(0.64)\end{array}$ & $\begin{array}{l}1.40 \\
(0.94)\end{array}$ & $\begin{array}{l}0.93 \\
(0.94)\end{array}$ & $\begin{array}{l}0.74 \\
(0.90)\end{array}$ & $\begin{array}{l}0.65 \\
(0.96)\end{array}$ \\
\hline
\end{tabular}


Code availability. The CMIP6 version of the ORCHIDEE model including the COS submodel is available on request to the authors. The LMDz model is available from http://web.lmd.jussieu. fr/LMDZ/LMDZ6/ (last access: 19 April 2021) under the CeCILL v2 Free Software License.

Data availability. For Hyytiälä, we used the 2015 eddy covariance flux data published in Kohonen (2020), the 2015 soil measurements published in Sun et al. (2018b), the 2017 branch chamber and eddy covariance fluxes published in Kooijmans et al. (2018), and local meteorological data available at https://smear.avaa.csc.fi/ (last access: 19 April 2021; Junninen et al., 2009). For Harvard, we used the data published in Commane et al. (2016).

Author contributions. FM and PP devised the research. CA and FM coded the ORCHIDEE developments and made the simulations. MR and PP dealt with the transport model. LMJK and KMK provided the Hyytiälä data. RC and RW provided the Harvard Forest data. JEC, SB, SAM, NR, US, YPS, NV, and MEW were consulted on their respective expertise. FM, CA, and MR analysed the results and wrote the first draft. All authors contributed to the manuscript.

Competing interests. The authors declare that they have no conflict of interest.

Acknowledgements. The authors thank the reviewers for their constructive and useful comments which helped to further improve this study. The LSCE group thanks the administrative and IT teams for managing the recruitment of Camille Abadie and providing the necessary facilities and tools to run the ORCHIDEE model and analyse the outputs. Operation of the US-Ha1 site is supported by the AmeriFlux Management Project with funding by the U.S. Department of Energy's Office of Science under contract no. DE-AC0205CH11231 and additionally is a part of the Harvard Forest LTER site supported by the National Science Foundation (DEB-1237491). The authors are very grateful to the ObsPack people who collected and archived the $\mathrm{CO}_{2}$ surface air samples used in this study.

Financial support. Camille Abadie, Fabienne Maignan, and Philippe Peylin have been mainly supported by the European Commission, Horizon 2020 Framework Programme, 4C (grant no. 821003) and to a smaller extent VERIFY (grant no. 776810). Marine Remaud was funded by the $\mathrm{CO}_{2}$ Human Emissions (CHE) project which received funding from the European Union's Horizon 2020 research and innovation programme under grant agreement no. 776186. Kukka-Maaria Kohonen thanks the Vilho, Yrjö, and Kalle Väisälä Fund and ICOS-FINLAND (319871) for their financial support. Linda M. J. Kooijmans received funding from the ERC project COSOCS under grant no. 742798.

Review statement. This paper was edited by Akihiko Ito and reviewed by Georg Wohlfahrt and one anonymous referee.

\section{References}

Allen, M., Babiker, M., Chen, Y., Taylor, M., Tschakert Australia, P., Waisman, H., Warren, R., Zhai, P., Zickfeld, K., Zhai, P., Pörtner, H., Roberts, D., Skea, J., Shukla, P., Pirani, A., Moufouma-Okia, W., Péan, C., Pidcock, R., Connors, S., Matthews, J., Chen, Y., Zhou, X., Gomis, M., Lonnoy, E., Maycock, T., Tignor, M., and Waterfield, T.: IPCCC 1.5C: Summary for Policymakers, Aromar Revi, available at: https://www.ipcc.ch/site/assets/uploads/sites/2/2019/05/ SR15_SPM_version_report_LR.pdf (last access: 19 April 2021), 2018.

Anav, A., Friedlingstein, P., Beer, C., Ciais, P., Harper, A., Jones, C., Murray-Tortarolo, G., Papale, D., Parazoo, N. C., Peylin, P., Piao, S., Sitch, S., Viovy, N., Wiltshire, A., and Zhao, M.: Spatiotemporal patterns of terrestrial gross primary production: A review, Rev. Geophys., 53, 785-818, https://doi.org/10.1002/2015RG000483, 2015.

Bacour, C., Maignan, F., MacBean, N., Porcar-Castell, A., Flexas, J., Frankenberg, C., Peylin, P., Chevallier, F., Vuichard, N., and Bastrikov, V.: Improving Estimates of Gross Primary Productivity by Assimilating Solar-Induced Fluorescence Satellite Retrievals in a Terrestrial Biosphere Model Using a ProcessBased SIF Model, J. Geophys. Res.-Biogeo., 124, 3281-3306, https://doi.org/10.1029/2019JG005040, 2019.

Badger, M. R. and Price, G. D.: The Role of Carbonic Anhydrase in Photosynthesis, Annu. Rev. Plant Physiol. Plant Mol. Biol., 45, 369-392, https://doi.org/10.1146/annurev.pp.45.060194.002101, 1994.

Ball, J. T., Woodrow, I. E., and Berry, J. A.: A Model Predicting Stomatal Conductance and its Contribution to the Control of Photosynthesis under Different Environmental Conditions, in: Progress in Photosynthesis Research, Springer, The Netherlands, 221-224, 1987.

Barkley, M. P., Palmer, P. I., Boone, C. D., Bernath, P. F., and Suntharalingam, P.: Global distributions of carbonyl sulfide in the upper troposphere and stratosphere, Geophys. Res. Lett., 35, L14810, https://doi.org/10.1029/2008GL034270, 2008.

Barnard, D. M. and Bauerle, W. L.: The implications of minimum stomatal conductance on modeling water flux in forest canopies, J. Geophys. Res.-Biogeo., 118, 1322-1333, https://doi.org/10.1002/jgrg.20112, 2013.

Berkelhammer, M., Asaf, D., Still, C., Montzka, S., Noone, D., Gupta, M., Provencal, R., Chen, H., and Yakir, D.: Constraining surface carbon fluxes using in situ measurements of carbonyl sulfide and carbon dioxide, Global Biogeochem. Cy., 28, 161-179, https://doi.org/10.1002/2013GB004644, 2014.

Berkelhammer, M., Alsip, B., Matamala, R., Cook, D., Whelan, M. E., Joo, E., Bernacchi, C., Miller, J., and Meyers, T.: Seasonal Evolution of Canopy Stomatal Conductance for a Prairie and Maize Field in the Midwestern United States from Continuous Carbonyl Sulfide Fluxes, Geophys. Res. Lett., 47, e2019GL085652, https://doi.org/10.1029/2019GL085652, 2020.

Berry, J., Wolf, A., Campbell, J. E., Baker, I., Blake, N., Blake, D., Denning, A. S., Kawa, S. R., Montzka, S. A., Seibt, U., Stimler, K., Yakir, D., and Zhu, Z.: A coupled model of the global cycles of carbonyl sulfide and $\mathrm{CO}_{2}$ : A possible new window on the carbon cycle, J. Geophys. Res.-Biogeo., 118, 842-852, https://doi.org/10.1002/jgrg.20068, 2013. 
Bloom, A. A., Exbrayat, J. F., Van Der Velde, I. R., Feng, L., and Williams, M.: The decadal state of the terrestrial carbon cycle: Global retrievals of terrestrial carbon allocation, pools, and residence times, P. Natl. Acad. Sci. USA, 113, 1285-1290, https://doi.org/10.1073/pnas.1515160113, 2016.

Botta, A., Viovy, N., Ciais, P., Friedlingstein, P., and Monfray, P.: A global prognostic scheme of leaf onset using satellite data, Global Change Biol., 6, 709-725, https://doi.org/10.1046/j.13652486.2000.00362.x, 2000.

Boucher, O., Servonnat, J., Albright, A. L., Aumont, O., Balkanski, Y., Bastrikov, V., Bekki, S., Bonnet, R., Bony, S., Bopp, L., Braconnot, P., Brockmann, P., Cadule, P., Caubel, A., Cheruy, F., Codron, F., Cozic, A., Cugnet, D., D’Andrea, F., Davini, P., de Lavergne, C., Denvil, S., Deshayes, J., Devilliers, M., Ducharne, A., Dufresne, J. L., Dupont, E., Éthé, C., Fairhead, L., Falletti, L., Flavoni, S., Foujols, M. A., Gardoll, S., Gastineau, G., Ghattas, J., Grandpeix, J. Y., Guenet, B., Guez, L. E., Guilyardi, E., Guimberteau, M., Hauglustaine, D., Hourdin, F., Idelkadi, A., Joussaume, S., Kageyama, M., Khodri, M., Krinner, G., Lebas, N., Levavasseur, G., Lévy, C., Li, L., Lott, F., Lurton, T., Luyssaert, S., Madec, G., Madeleine, J. B., Maignan, F., Marchand, M., Marti, O., Mellul, L., Meurdesoif, Y., Mignot, J., Musat, I., Ottlé, C., Peylin, P., Planton, Y., Polcher, J., Rio, C., Rochetin, N., Rousset, C., Sepulchre, P., Sima, A., Swingedouw, D., Thiéblemont, R., Traore, A. K., Vancoppenolle, M., Vial, J., Vialard, J., Viovy, N., and Vuichard, N.: Presentation and Evaluation of the IPSL-CM6A-LR Climate Model, J. Adv. Model. Earth Syst., 12, e2019MS002010, doi:10.1029/2019MS002010, 2020.

Breiman, L.: Random forests, Mach. Learn., 45, 5-32, https://doi.org/10.1023/A:1010933404324, 2001.

Buckley, T. N. and Warren, C. R.: The role of mesophyll conductance in the economics of nitrogen and water use in photosynthesis, Photosynth. Res., 119, 77-88, https://doi.org/10.1007/s11120-013-9825-2, 2014.

Caird, M. A., Richards, J. H., and Donovan, L. A.: Nighttime stomatal conductance and transpiration in $\mathrm{C}_{3}$ and $\mathrm{C}_{4}$ plants, Plant Physiol., 143, 4-10, https://doi.org/10.1104/pp.106.092940, 2007.

Campbell, J. E., Carmichael, G. R., Chai, T., Mena-Carrasco, M., Tang, Y., Blake, D. R., Blake, N. J., Vay, S. A., Collatz, G. J., Baker, I., Berry, J. A., Montzka, S. A., Sweeney, C., Schnoor, J. L., and Stanier, C. O.: Photosynthetic Control of Atmospheric Carbonyl Sulfide During the Growing Season, Science, 322, 1085-1088, https://doi.org/10.1126/science.1164015, 2008.

Campbell, J. E., Berry, J. A., Seibt, U., Smith, S. J., Montzka, S. A., Launois, T., Belviso, S., Bopp, L., and Laine, M.: Large historical growth in global terrestrial gross primary production, Nature, 544, 84-87, https://doi.org/10.1038/nature22030, 2017.

Ciais, P., Sabine, C., Bala, G., Bopp, L., Brovkin, V., Canadell, J., Chhabra, A., DeFries, R., Galloway, J., Heimann, M., Jones, C., Le Quéré, C., Myneni, R. B., Piao, S., and Thornton, P.: Carbon and other biogeochemical cycles, in: Climate Change 2013, the Physical Science Basis: Working Group I - Contribution to the Fifth Assessment Report of the Intergovernmental Panel on Climate Change, 465-570, https://doi.org/10.1017/CBO9781107415324.015, 2013.

Collatz, G., Ribas-Carbo, M., and Berry, J.: Coupled Photosynthesis-Stomatal Conductance Model for
Leaves of $\mathrm{C}_{4}$ Plants, Funct. Plant Biol., 19, 519-538, https://doi.org/10.1071/pp9920519, 1992.

Commane, R., Meredith, L. K., Baker, I. T., Berry, J. A., Munger, J. W., Montzka, S. A., Templer, P. H., Juice, S. M., Zahniser, M. S., and Wofsy, S. C.: Seasonal fluxes of carbonyl sulfide in a midlatitude forest, P. Natl. Acad. Sci. USA, 112, 14162-14167, https://doi.org/10.1073/pnas.1504131112, 2015.

Commane, R., Lindaas, J., Benmergui, J., Luus, K. A., Chang, R. Y. W., Daube, B. C., Euskirchen, E. S., Henderson, J. M., Karion, A., Miller, J. B., Miller, S. M., Parazoo, N. C., Randerson, J. T., Sweeney, C., Tans, P., Thoning, K., Veraverbeke, S., Miller, C. E., and Wofsy, S. C.: Carbon dioxide sources from Alaska driven by increasing early winter respiration from Arctic tundra, P. Natl. Acad. Sci. USA, 114, 5361-5366, https://doi.org/10.1073/pnas.1618567114, 2017.

Commane, R., Wofsy, S., and Weir, R.: Fluxes of Carbonyl Sulfide at Harvard Forest EMS Tower since 2010 version 4, Environmental Data Initiative [data set], https://doi.org/10.6073/pasta/7ed7b4d1fc7ad303998e76143a3b279a (last access: 19 April 2021), 2016.

Conway, T. J., Tans, P. P., and Waterman, L. S.: Atmospheric $\mathrm{CO}_{2}$ records from sites in the NOAA/CMDL air sampling network, in: Trends' 93: A Compendium of Data on Global Change, edited by: Boden, T. A., Kaiser, D. P., Sepanski, R. J., and Stoss, F. W., National Laboratory, Oak Ridge, Tennessee, USA, 41-119, 1994.

Cooperative Global Atmospheric Data Integration Project: Multi-laboratory compilation of atmospheric carbon dioxide data for the period 1957-2017; obspack_co2_1_GLOBALVIEWplus_v4.0_2018-08-02, NOAA Earth System Research Laboratory, Global Monitoring Division [data set], https://doi.org/10.25925/20180802, 2018.

de Rosnay, P. and Polcher, J.: Modelling root water uptake in a complex land surface scheme coupled to a GCM, Hydrol. Earth Syst. Sci., 2, 239-255, https://doi.org/10.5194/hess-2-239-1998, 1998.

Dufresne, J. L., Foujols, M. A., Denvil, S., Caubel, A., Marti, O., Aumont, O., Balkanski, Y., Bekki, S., Bellenger, H., Benshila, R., Bony, S., Bopp, L., Braconnot, P., Brockmann, P., Cadule, P., Cheruy, F., Codron, F., Cozic, A., Cugnet, D., de Noblet, N., Duvel, J. P., Ethé, C., Fairhead, L., Fichefet, T., Flavoni, S., Friedlingstein, P., Grandpeix, J. Y., Guez, L., Guilyardi, E., Hauglustaine, D., Hourdin, F., Idelkadi, A., Ghattas, J., Joussaume, S., Kageyama, M., Krinner, G., Labetoulle, S., Lahellec, A., Lefebvre, M. P., Lefevre, F., Levy, C., Li, Z. X., Lloyd, J., Lott, F., Madec, G., Mancip, M., Marchand, M., Masson, S., Meurdesoif, Y., Mignot, J., Musat, I., Parouty, S., Polcher, J., Rio, C., Schulz, M., Swingedouw, D., Szopa, S., Talandier, C., Terray, P., Viovy, N., and Vuichard, N.: Climate change projections using the IPSL-CM5 Earth System Model: From CMIP3 to CMIP5, Clim. Dynam., 40, 2123-2165, https://doi.org/10.1007/s00382012-1636-1, 2013.

Evans, J. R., von Caemmerer, S., Setchell, B. A., and Hudson, G. S.: The relationship between $\mathrm{CO}_{2}$ transfer conductance and leaf anatomy in transgenic tobacco with a reduced content of Rubisco, Aust. J. Plant Physiol., 21, 475-495, https://doi.org/10.1071/PP9940475, 1994.

Farquhar, G. D., von Caemmerer, S., and Berry, J. A.: A biochemical model of photosynthetic $\mathrm{CO}_{2}$ assim- 
ilation in leaves of $\mathrm{C}_{3}$ species, Planta, 149, 78-90, https://doi.org/10.1007/BF00386231, 1980.

Farquhar, G. D., Lloyd, J., Taylor, J. A., Flanagan, L. B., Syvertsen, J. P., Hubick, K. T., Wong, S. C., and Ehleringer, J. R.: Vegetation effects on the isotope composition of oxygen in atmospheric $\mathrm{CO}_{2}$, Nature, 363, 439-443, https://doi.org/10.1038/363439a0, 1993.

Folberth, G. A., Hauglustaine, D. A., Lathière, J., and Brocheton, F.: Interactive chemistry in the Laboratoire de Météorologie Dynamique general circulation model: model description and impact analysis of biogenic hydrocarbons on tropospheric chemistry, Atmos. Chem. Phys., 6, 2273-2319, https://doi.org/10.5194/acp-6-2273-2006, 2006.

Friedlingstein, P., Jones, M. W., O’Sullivan, M., Andrew, R. M., Hauck, J., Peters, G. P., Peters, W., Pongratz, J., Sitch, S., Le Quéré, C., Bakker, D. C. E., Canadell, J. G., Ciais, P., Jackson, R. B., Anthoni, P., Barbero, L., Bastos, A., Bastrikov, V., Becker, M., Bopp, L., Buitenhuis, E., Chandra, N., Chevallier, F., Chini, L. P., Currie, K. I., Feely, R. A., Gehlen, M., Gilfillan, D., Gkritzalis, T., Goll, D. S., Gruber, N., Gutekunst, S., Harris, I., Haverd, V., Houghton, R. A., Hurtt, G., Ilyina, T., Jain, A. K., Joetzjer, E., Kaplan, J. O., Kato, E., Klein Goldewijk, K., Korsbakken, J. I., Landschützer, P., Lauvset, S. K., Lefèvre, N., Lenton, A., Lienert, S., Lombardozzi, D., Marland, G., McGuire, P. C., Melton, J. R., Metzl, N., Munro, D. R., Nabel, J. E. M. S., Nakaoka, S.-I., Neill, C., Omar, A. M., Ono, T., Peregon, A., Pierrot, D., Poulter, B., Rehder, G., Resplandy, L., Robertson, E., Rödenbeck, C., Séférian, R., Schwinger, J., Smith, N., Tans, P. P., Tian, H., Tilbrook, B., Tubiello, F. N., van der Werf, G. R., Wiltshire, A. J., and Zaehle, S.: Global Carbon Budget 2019, Earth Syst. Sci. Data, 11, 1783-1838, https://doi.org/10.5194/essd-111783-2019, 2019.

Friend, A. D., Arneth, A., Kiang, N. Y., Lomas, M., Ogée, J., Rödenbeck, C., Running, S. W., Santaren, J. D., Sitch, S., Viovy, N., Ian Woodward, F., and Zaehle, S.: FLUXNET and modelling the global carbon cycle, Global Change Biol., 13, 610 633, https://doi.org/10.1111/j.1365-2486.2006.01223.x, 2007.

Gimeno, T. E., Ogée, J., Royles, J., Gibon, Y., West, J. B., Burlett, R., Jones, S. P., Sauze, J., Wohl, S., Benard, C., Genty, B., and Wingate, L.: Bryophyte gas-exchange dynamics along varying hydration status reveal a significant carbonyl sulphide (COS) sink in the dark and COS source in the light, New Phytol., 215, 965-976, https://doi.org/10.1111/nph.14584, 2017.

Goldan, P. D., Fall, R., Kuster, W. C., and Fehsenfeld, F. C.: Uptake of COS by growing vegetation: A major tropospheric sink, J. Geophys. Res.-Atmos., 93, 14186-14192, https://doi.org/10.1029/JD093iD11p14186, 1988.

Graven, H. D., Keeling, R. F., Piper, S. C., Patra, P. K., Stephens, B. B., Wofsy, S. C., Welp, L. R., Sweeney, C., Tans, P. P., Kelley, J. J., Daube, B. C., Kort, E. A., Santoni, G. W., and Bent, J. D.: Enhanced seasonal exchange of $\mathrm{CO}_{2}$ by Northern ecosystems since 1960, Science, 341, 1085-1089, https://doi.org/10.1126/science.1239207, 2013.

Hauglustaine, D. A., Hourdin, F., Jourdain, L., Filiberti, M. A., Walters, S., Lamarque, J. F., and Holland, E. A.: Interactive chemistry in the Laboratoire de Météorologie Dynamique general circulation model: Description and background tropospheric chemistry evaluation, J. Geophys. Res.-Atmos., 109, D04314, https://doi.org/10.1029/2003JD003957, 2004.
Hauglustaine, D. A., Balkanski, Y., and Schulz, M.: A global model simulation of present and future nitrate aerosols and their direct radiative forcing of climate, Atmos. Chem. Phys., 14, 1103111063, https://doi.org/10.5194/acp-14-11031-2014, 2014.

Henry R. P.: Techniques for measuring carbonic anhydrase activity in vitro: the electrometric delta $\mathrm{pH}$ and $\mathrm{pH}$ stat assay, in: The Carbonic Anhydrases: Cellular Physiology and Molecular Genetics, edited by: Dodgson, S. J., Tashian R. E., Gros, G., and Carter, N. D., New York, Plenum, 11-126, 1991.

Hilton, T. W., Zumkehr, A., Kulkarni, S., Berry, J., Whelan, M. E., and Elliott Campbell, J.: Large variability in ecosystem models explains uncertainty in a critical parameter for quantifying GPP with carbonyl sulphide, Tellus B, 67, 26329, https://doi.org/10.3402/tellusb.v67.26329, 2015.

Hilton, T. W., Whelan, M. E., Zumkehr, A., Kulkarni, S. Berry, J. A., Baker, I. T., Montzka, S. A., Sweeney, C., Miller, B. R., and Elliott Campbell, J.: Peak growing season gross uptake of carbon in North America is largest in the Midwest USA, Nat. Clim. Change, 7, 450-454, https://doi.org/10.1038/nclimate3272, 2017.

Hourdin, F. and Talagrand, O.: Eulerian backtracking of atmospheric tracers, I: Adjoint derivation and parametrization of subgrid-scale transport, Q. J. Roy. Meteor. Soc., 132, 567-583, https://doi.org/10.1256/qj.03.198.A, 2006.

Hourdin, F., Talagrand, O., and Idelkadi, A.: Eulerian backtracking of atmospheric tracers, II: Numerical aspects, Q. J. Roy. Meteor Soc., 132, 585-603, https://doi.org/10.1256/qj.03.198.B, 2006.

IPCC: Summary for Policymakers, in: Climate Change and Land: an IPCC special report on climate change, desertification, land degradation, sustainable land management, food security, and greenhouse gas fluxes in terrestrial ecosystems, edited by: Shukla, P. R., Skea, J., Calvo Buendia, E., Masson-Delmotte, V., Pörtner, H.-O., Roberts, D. C., Zhai, P., Slade, R., Connors, S., van Diemen, R., Ferrat, M., Haughey, E., Luz, S., Neogi, S., Pathak, M., Petzold, J., Portugal Pereira, J., Vyas, P., Huntley, E., Kissick, K., Belkacemi, M., and Malley, J., in press., 2019a.

IPCC: Summary for Policymakers, in: IPCC Special Report on the Ocean and Cryosphere in a Changing Climate, edited by: Pörtner, H.-O., Roberts, D. C., Masson-Delmotte, V., Zhai, P., Tignor, M., Poloczanska, E., Mintenbeck, K., Alegri`a, A., Nicolai, M., Okem, A., Petzold, J., Rama, B., and Weyer, N. M., in press, 2019b.

Joiner, J., Yoshida, Y., Zhang, Y., Duveiller, G., Jung, M., Lyapustin, A., Wang, Y., and Tucker, C.: Estimation of Terrestrial Global Gross Primary Production (GPP) with Satellite DataDriven Models and Eddy Covariance Flux Data, Remote Sens.Basel, 10, 1346, https://doi.org/10.3390/rs10091346, 2018.

Junninen, H., Lauri, A., Keronen, P., Aalto, P., Hiltunen, V., Hari, P., and Kulmala, M.: Smart-SMEAR: on-line data exploration and visualization tool for SMEAR stations, Boreal Environ. Res., 14, 447-457, 2009.

Kattge, J. and Knorr, W.: Temperature acclimation in a biochemical model of photosynthesis: A reanalysis of data from 36 species, Plant Cell Environ., 30, 1176-1190, https://doi.org/10.1111/j.1365-3040.2007.01690.x, 2007.

Kettle, A. J., Kuhn, U., Von Hobe, M., Kesselmeier, J., and Andreae, M. O.: Global budget of atmospheric carbonyl sulfide: Temporal and spatial variations of the domi- 
nant sources and sinks, J. Geophys. Res.-Atmos., 107, 4658, https://doi.org/10.1029/2002JD002187, 2002.

Kitz, F., Spielmann, F. M., Hammerle, A., Kolle, O., Migliavacca, M., Moreno, G., Ibrom, A., Krasnov, D., Noe, S. M., and Wohlfahrt, G.: Soil COS Exchange: A Comparison of Three European Ecosystems, Global Biogeochem. Cy., 34, e2019GB006202, https://doi.org/10.1029/2019GB006202, 2020.

Kohonen, K.-M.: Data for "Towards standardized processing of eddy covariance flux measurements of carbonyl sulfide", Zenodo [data set], https://doi.org/10.5281/zenodo.3907342 (last access: 19 April 2021), 2020.

Kohonen, K.-M., Kolari, P., Kooijmans, L. M. J., Chen, H., Seibt, U., Sun, W., and Mammarella, I.: Towards standardized processing of eddy covariance flux measurements of carbonyl sulfide, Atmos. Meas. Tech., 13, 3957-3975, https://doi.org/10.5194/amt-13-3957-2020, 2020.

Kooijmans, L. M. J., Uitslag, N. A. M., Zahniser, M. S., Nelson, D. D., Montzka, S. A., and Chen, H.: Continuous and high-precision atmospheric concentration measurements of $\mathrm{COS}, \mathrm{CO}_{2}, \mathrm{CO}$ and $\mathrm{H}_{2} \mathrm{O}$ using a quantum cascade laser spectrometer (QCLS), Atmos. Meas. Tech., 9, 5293-5314, https://doi.org/10.5194/amt-95293-2016, 2016.

Kooijmans, L. M. J., Maseyk, K., Seibt, U., Sun, W., Vesala, T., Mammarella, I., Kolari, P., Aalto, J., Franchin, A., Vecchi, R., Valli, G., and Chen, H.: Canopy uptake dominates nighttime carbonyl sulfide fluxes in a boreal forest, Atmos. Chem. Phys., 17, 11453-11465, https://doi.org/10.5194/acp-17-114532017, 2017.

Kooijmans, L. M. J., Sun, W., Aalto, J., Erkkilä, K.-M., Maseyk, K., Seibt, U., Vesala, T., Mammarella, I., and Chen, H.: Dataset for "Influences of light and humidity on carbonyl sulfide-based estimates of photosynthesis", Zenodo [data set], https://zenodo.org/ record/1211481\#.XEC-NVVKhQJ (last access: 19 April 2021), 2018.

Kooijmans, L. M. J., Sun, W., Aalto, J., Erkkilä, K. M., Maseyk, K., Seibt, U., Vesala, T., Mammarella, I., and Chen, H.: Influences of light and humidity on carbonyl sulfide-based estimates of photosynthesis, P. Natl. Acad. Sci. USA, 116, 2470-2475, https://doi.org/10.1073/pnas.1807600116, 2019.

Krinner, G., Viovy, N., de Noblet-Ducoudré, N., Ogée, J., Polcher, J., Friedlingstein, P., Ciais, P., Sitch, S., and Prentice, I. C.: A dynamic global vegetation model for studies of the coupled atmosphere-biosphere system, Global Biogeochem. Cy., 19, GB1015, https://doi.org/10.1029/2003GB002199, 2005.

Kuppel, S., Peylin, P., Chevallier, F., Bacour, C., Maignan, F., and Richardson, A. D.: Constraining a global ecosystem model with multi-site eddy-covariance data, Biogeosciences, 9, 3757-3776, https://doi.org/10.5194/bg-9-3757-2012, 2012.

Kuppel, S., Peylin, P., Maignan, F., Chevallier, F., Kiely, G., Montagnani, L., and Cescatti, A.: Model-data fusion across ecosystems: from multisite optimizations to global simulations, Geosci. Model Dev., 7, 2581-2597, https://doi.org/10.5194/gmd-7-25812014, 2014.

Landschützer, P., Gruber, N., and Bakker, D. C. E.: A 30 years observation-based global monthly gridded sea surface $p \mathrm{CO}_{2}$ product from 1982 through 2011 (NCEI Accession 0160558) [Dataset], Version 2.2, NOAA National Centers for Environmental Information, available at: https://doi.org/10.3334/cdiac/otg.spco2_1982_2011_eth_somffn, 2015.

Lardy, R., Bellocchi, G., and Soussana, J.: A new method to determine soil organic carbon equilibrium, Environ. Modell. Softw., 26, 1759-1763, https://doi.org/10.1016/j.envsoft.2011.05.016, 2011.

Launois, T., Belviso, S., Bopp, L., Fichot, C. G., and Peylin, P.: A new model for the global biogeochemical cycle of carbonyl sulfide - Part 1: Assessment of direct marine emissions with an oceanic general circulation and biogeochemistry model, Atmos. Chem. Phys., 15, 2295-2312, https://doi.org/10.5194/acp15-2295-2015, 2015a.

Launois, T., Peylin, P., Belviso, S., and Poulter, B.: A new model of the global biogeochemical cycle of carbonyl sulfide - Part 2: Use of carbonyl sulfide to constrain gross primary productivity in current vegetation models, Atmos. Chem. Phys., 15, 9285-9312, https://doi.org/10.5194/acp-15-9285-2015, 2015b.

Le Quéré, C., Andrew, R. M., Friedlingstein, P., Sitch, S., Hauck, J., Pongratz, J., Pickers, P. A., Korsbakken, J. I., Peters, G. P., Canadell, J. G., Arneth, A., Arora, V. K., Barbero, L., Bastos, A., Bopp, L., Chevallier, F., Chini, L. P., Ciais, P., Doney, S. C., Gkritzalis, T., Goll, D. S., Harris, I., Haverd, V., Hoffman, F. M., Hoppema, M., Houghton, R. A., Hurtt, G., Ilyina, T., Jain, A. K., Johannessen, T., Jones, C. D., Kato, E., Keeling, R. F., Goldewijk, K. K., Landschützer, P., Lefèvre, N., Lienert, S., Liu, Z., Lombardozzi, D., Metzl, N., Munro, D. R., Nabel, J. E. M. S., Nakaoka, S., Neill, C., Olsen, A., Ono, T., Patra, P., Peregon, A., Peters, W., Peylin, P., Pfeil, B., Pierrot, D., Poulter, B., Rehder, G., Resplandy, L., Robertson, E., Rocher, M., Rödenbeck, C., Schuster, U., Schwinger, J., Séférian, R., Skjelvan, I., Steinhoff, T., Sutton, A., Tans, P. P., Tian, H., Tilbrook, B., Tubiello, F. N., van der Laan-Luijkx, I. T., van der Werf, G. R., Viovy, N., Walker, A. P., Wiltshire, A. J., Wright, R., Zaehle, S., and Zheng, B.: Global Carbon Budget 2018, Earth Syst. Sci. Data, 10, 21412194, https://doi.org/10.5194/essd-10-2141-2018, 2018.

Lee, E., Zeng, F.-W., Koster, R. D., Weir, B., Ott, L. E., and Poulter, B.: The impact of spatiotemporal variability in atmospheric $\mathrm{CO}_{2}$ concentration on global terrestrial carbon fluxes, Biogeosciences, 15, 5635-5652, https://doi.org/10.5194/bg-15-5635-2018, 2018.

Lennartz, S. T., Marandino, C. A., von Hobe, M., Cortes, P., Quack, B., Simo, R., Booge, D., Pozzer, A., Steinhoff, T., ArevaloMartinez, D. L., Kloss, C., Bracher, A., Röttgers, R., Atlas, E., and Krüger, K.: Direct oceanic emissions unlikely to account for the missing source of atmospheric carbonyl sulfide, Atmos. Chem. Phys., 17, 385-402, https://doi.org/10.5194/acp-17-3852017, 2017.

Lombardozzi, D. L., Zeppel, M. J. B., Fisher, R. A., and Tawfik, A.: Representing nighttime and minimum conductance in CLM4.5: global hydrology and carbon sensitivity analysis using observational constraints, Geosci. Model Dev., 10, 321-331, https://doi.org/10.5194/gmd-10-321-2017, 2017.

Ma, J., Kooijmans, L. M. J., Cho, A., Montzka, S. A., Glatthor, N., Worden, J. R., Kuai, L., Atlas, E. L., and Krol, M. C.: Inverse modelling of carbonyl sulfide: implementation, evaluation and implications for the global budget, Atmos. Chem. Phys., 21, 3507-3529, https://doi.org/10.5194/acp-21-3507-2021, 2021.

MacBean, N., Maignan, F., Peylin, P., Bacour, C., Bréon, F.-M., and Ciais, P.: Using satellite data to improve the leaf phenology of 
a global terrestrial biosphere model, Biogeosciences, 12, 71857208, https://doi.org/10.5194/bg-12-7185-2015, 2015.

Maseyk, K., Berry, J. A., Billesbach, D., Campbell, J. E., Torn, M. S., Zahniser, M., and Seibt, U.: Sources and sinks of carbonyl sulfide in an agricultural field in the Southern Great Plains, P. Natl. Acad. Sci. USA, 111, 9064-9069, https://doi.org/10.1073/pnas.1319132111, 2014.

Medlyn, B. E., Dreyer, E., Ellsworth, D., Forstreuter, M., Harley, P. C., Kirschbaum, M. U. F., Le Roux, X., Montpied, P., Strassemeyer, J., Walcroft, A., Wang, K., and Loustau, D.: Temperature response of parameters of a biochemically based model of photosynthesis, II. A review of experimental data, Plant Cell Environ., 25, 1167-1179, https://doi.org/10.1046/j.13653040.2002.00891.x, 2002.

Montzka, S. A., Calvert, P., Hall, B. D., Elkins, J. W., Conway, T. J., Tans, P. P., and Sweeney, C. S.: On the global distribution, seasonality, and budget of atmospheric carbonyl sulfide (COS) and some similarities to $\mathrm{CO}_{2}$, J. Geophys. Res.-Atmos., 112, D09302, https://doi.org/10.1029/2006JD007665, 2007.

Morris, M. D.: Factorial Sampling Plans for Preliminary Computational Experiments, Technometrics, 33, 161-174, https://doi.org/10.2307/1269043, 1991.

Norton, A. J., Rayner, P. J., Koffi, E. N., Scholze, M., Silver, J. D., and Wang, Y.-P.: Estimating global gross primary productivity using chlorophyll fluorescence and a data assimilation system with the BETHY-SCOPE model, Biogeosciences, 16, 30693093, https://doi.org/10.5194/bg-16-3069-2019, 2019.

Notni, J., Schenk, S., Protoschill-Krebs, G., Kesselmeier, J., and Anders, E.: The Missing Link in COS Metabolism: A Model Study on the Reactivation of Carbonic Anhydrase from its Hydrosulfide Analogue, ChemBioChem, 8, 530-536, https://doi.org/10.1002/cbic.200600436, 2007.

Ogawa, T., Noguchi, K., Saito, M., Nagahata, Y., Kato, H., Ohtaki, A., Nakayama, H., Dohmae, N., Matsushita, Y., Odaka, M., Yohda, M., Nyunoya, H., and Katayama, Y.: Carbonyl sulfide hydrolase from Thiobacillus thioparus strain THI115 is one of the $\beta$-carbonic anhydrase family enzymes, J. Am. Chem. Soc., 135, 3818-3825, https://doi.org/10.1021/ja307735e, 2013.

Ogée, J., Sauze, J., Kesselmeier, J., Genty, B., Van Diest, H., Launois, T., and Wingate, L.: A new mechanistic framework to predict OCS fluxes from soils, Biogeosciences, 13, 2221-2240, https://doi.org/10.5194/bg-13-2221-2016, 2016.

Parazoo, N. C., Denning, A. S., Berry, J. A., Wolf, A., Randall, D. A., Kawa, S. R., Pauluis, O., and Doney, S. C.: Moist synoptic transport of $\mathrm{CO}_{2}$ along the midlatitude storm track, Geophys. Res. Lett., 38, 2011GL047238, https://doi.org/10.1029/2011GL047238, 2011.

Peters, W., van der Velde, I. R., van Schaik, E., Miller, J. B., Ciais, P., Duarte, H. F., van der Laan-Luijkx, I. T., van der Molen, M. K., Scholze, M., Schaefer, K., Vidale, P. L., Verhoef, A., Wårlind, D., Zhu, D., Tans, P. P., Vaughn, B., and White, J. W. C.: Increased water-use efficiency and reduced $\mathrm{CO}_{2}$ uptake by plants during droughts at a continental scale, Nat. Geosci., 11, 744-748, https://doi.org/10.1038/s41561-018-0212-7, 2018.

Peylin, P., Ciais, P., Denning, A. S., Tans, P. P., Berry, J. A., and White, J. W. C.: A 3-dimensional study of $\delta^{18} \mathrm{O}$ in atmospheric $\mathrm{CO}_{2}$ : Contribution of different land ecosystems, Tellus B, 51, 642-667, https://doi.org/10.3402/tellusb.v51i3.16452, 1999.
Phillips, N. G., Lewis, J. D., Logan, B. A., and Tissue, D. T.: Inter- and intra-specific variation in nocturnal water transport in Eucalyptus, Tree Physiol., 30, 586-596, https://doi.org/10.1093/treephys/tpq009, 2010.

Poulter, B., MacBean, N., Hartley, A., Khlystova, I., Arino, O., Betts, R., Bontemps, S., Boettcher, M., Brockmann, C., Defourny, P., Hagemann, S., Herold, M., Kirches, G., Lamarche, C., Lederer, D., Ottlé, C., Peters, M., and Peylin, P.: Plant functional type classification for earth system models: results from the European Space Agency's Land Cover Climate Change Initiative, Geosci. Model Dev., 8, 2315-2328, https://doi.org/10.5194/gmd8-2315-2015, 2015.

Prentice, I. C., Dong, N., Gleason, S. M., Maire, V., and Wright, I. $\mathrm{J}$.: Balancing the costs of carbon gain and water transport: Testing a new theoretical framework for plant functional ecology, Ecol. Lett., 17, 82-91, https://doi.org/10.1111/ele.12211, 2014.

Protoschill-Krebs, G., Wilhelm, C., and Kesselmeier, J.: Consumption of carbonyl sulphide (COS) by higher plant carbonic anhydrase (CA), Atmos. Environ., 30, 3151-3156, https://doi.org/10.1016/1352-2310(96)00026-X, 1996.

Rastogi, B., Berkelhammer, M., Wharton, S., Whelan, M. E., Itter, M. S., Leen, J. B., Gupta, M. X., Noone, D., and Still, C. J.: Large Uptake of Atmospheric OCS Observed at a Moist Old Growth Forest: Controls and Implications for Carbon Cycle Applications, J. Geophys. Res.-Biogeo., 123, 3424-3438, https://doi.org/10.1029/2018JG004430, 2018.

Rayner, P. J., Scholze, M., Knorr, W., Kaminski, T., Giering, R., and Widmann, H.: Two decades of terrestrial carbon fluxes from a carbon cycle data assimilation system (CCDAS), Global Biogeochem. Cy., 19, GB2026, https://doi.org/10.1029/2004GB002254, 2005.

Remaud, M., Chevallier, F., Cozic, A., Lin, X., and Bousquet, P.: On the impact of recent developments of the LMDz atmospheric general circulation model on the simulation of $\mathrm{CO}_{2}$ transport, Geosci. Model Dev., 11, 4489-4513, https://doi.org/10.5194/gmd-11-4489-2018, 2018.

Sadok, W. and Jagadish, S. V. K.: The Hidden Costs of Nighttime Warming on Yields, Trends Plant Sci., 25, 644-651, https://doi.org/10.1016/j.tplants.2020.02.003, 2020.

Sandoval-Soto, L., Stanimirov, M., von Hobe, M., Schmitt, V., Valdes, J., Wild, A., and Kesselmeier, J.: Global uptake of carbonyl sulfide (COS) by terrestrial vegetation: Estimates corrected by deposition velocities normalized to the uptake of carbon dioxide $\left(\mathrm{CO}_{2}\right)$, Biogeosciences, 2, 125-132, https://doi.org/10.5194/bg-2-125-2005, 2005.

Seibt, U., Kesselmeier, J., Sandoval-Soto, L., Kuhn, U., and Berry, J. A.: A kinetic analysis of leaf uptake of COS and its relation to transpiration, photosynthesis and carbon isotope fractionation, Biogeosciences, 7, 333-341, https://doi.org/10.5194/bg-7333-2010, 2010.

Serio, C., Masiello, G., Mastro, P., Cersosimo, A., Pasquariello, P., and Venafra, S.: Simultaneous retrieval of OCS, and $\mathrm{CO}_{2}$ from the IASI shortwave spectral band: assessment of the accuracy of the retrieval products and validation with in situ observations, in: Proceedings Society of Photo-Optical Instrumentation Engineers (SPIE), Remote Sensing of Clouds and the Atmosphere XXV, Online Only, 20 September 2020, 11531, 1153107, https://doi.org/10.1117/12.2573351, 2020. 
Sitch, S., Friedlingstein, P., Gruber, N., Jones, S. D., MurrayTortarolo, G., Ahlström, A., Doney, S. C., Graven, H., Heinze, C., Huntingford, C., Levis, S., Levy, P. E., Lomas, M., Poulter, B., Viovy, N., Zaehle, S., Zeng, N., Arneth, A., Bonan, G., Bopp, L., Canadell, J. G., Chevallier, F., Ciais, P., Ellis, R., Gloor, M., Peylin, P., Piao, S. L., Le Quéré, C., Smith, B., Zhu, Z., and Myneni, R.: Recent trends and drivers of regional sources and sinks of carbon dioxide, Biogeosciences, 12, 653679, https://doi.org/10.5194/bg-12-653-2015, 2015.

Sobol, I. M.: Global sensitivity indices for nonlinear mathematical models and their Monte Carlo estimates, Math. Comput. Simul., 55, 271-280, https://doi.org/10.1016/S0378-4754(00)00270-6, 2001.

Stangl, Z. R., Tarvainen, L., Wallin, G., Ubierna, N., Räntfors, M., and Marshall, J. D.: Diurnal variation in mesophyll conductance and its influence on modelled water-use efficiency in a mature boreal Pinus sylvestris stand, Photosynth. Res., 141, 53-63, https://doi.org/10.1007/s11120-019-00645-6, 2019.

Stimler, K., Montzka, S. A., Berry, J. A., Rudich, Y., and Yakir, D.: Relationships between carbonyl sulfide (COS) and $\mathrm{CO}_{2}$ during leaf gas exchange, New Phytol., 186, 869-878, https://doi.org/10.1111/j.1469-8137.2010.03218.x, 2010.

Stimler, K., Berry, J. A., Montzka, S. A., and Yakir, D.: Association between carbonyl sulfide uptake and $18 \Delta$ during gas exchange in $C_{3}$ and $C_{4}$ leaves, Plant Physiol., 157, 509-517, https://doi.org/10.1104/pp.111.176578, 2011.

Stinecipher, J. R., Cameron-Smith, P. J., Blake, N. J., Kuai, L., Lejeune, B., Mahieu, E., Simpson, I. J., and Campbell, J. E.: Biomass Burning Unlikely to Account for Missing Source of Carbonyl Sulfide, Geophys. Res. Lett., 46, 14912-14920, https://doi.org/10.1029/2019GL085567, 2019.

Sun, W., Maseyk, K., Lett, C., and Seibt, U.: A soil diffusionreaction model for surface COS flux: COSSM v1, Geosci. Model Dev., 8, 3055-3070, https://doi.org/10.5194/gmd-8-3055-2015, 2015.

Sun, W., Kooijmans, L. M. J., Maseyk, K., Chen, H., Mammarella, I., Vesala, T., Levula, J., Keskinen, H., and Seibt, U.: Soil fluxes of carbonyl sulfide (COS), carbon monoxide, and carbon dioxide in a boreal forest in southern Finland, Atmos. Chem. Phys., 18, 1363-1378, https://doi.org/10.5194/acp-18-1363-2018, 2018a.

Sun, W., Kooijmans, L. M. J., Maseyk, K., Chen, H., Mammarella, I., Vesala, T., Levula, J., Keskinen, H., and Seibt, U.: Dataset for "Soil fluxes of carbonyl sulfide (COS), carbon monoxide, and carbon dioxide in a boreal forest in southern Finland", Zenodo [data set], https://zenodo.org/record/322936\# .YH7KLZ9xeUk (last access: 19 April 2021), 2018 b.

Sun, W., Maseyk, K., Lett, C., and Seibt, U.: Stomatal control of leaf fluxes of carbonyl sulfide and $\mathrm{CO}_{2}$ in a Typha freshwater marsh, Biogeosciences, 15, 3277-3291, https://doi.org/10.5194/bg-153277-2018, 2018c.

Suntharalingam, P., Kettle, A. J., Montzka, S. M., and Jacob, D. J.: Global 3-D model analysis of the seasonal cycle of atmospheric carbonyl sulfide: Implications for terrestrial vegetation uptake, Geophys. Res. Lett., 35, L19801, https://doi.org/10.1029/2008GL034332, 2008.

Tarantola, A.: Inverse problem theory: methods for data fitting and model parameter estimation, Elsevier, Amsterdam, The Netherlands, 1987.
Thoning, K. W., Tans, P. P., and Komhyr, W. D.: Atmospheric carbon dioxide at Mauna Loa Observatory, 2. Analysis of the NOAA GMCC data 1974-1985, J. Geophys. Res.-Atmos., 94, 85498565, https://doi.org/10.1029/JD094iD06p08549, 1989.

von Caemmerer, S. and Evans, J. R.: Temperature responses of mesophyll conductance differ greatly between species, Plant. Cell Environ., 38, 629-637, https://doi.org/10.1111/pce.12449, 2015.

Wehr, R., Commane, R., Munger, J. W., McManus, J. B., Nelson, D. D., Zahniser, M. S., Saleska, S. R., and Wofsy, S. C.: Dynamics of canopy stomatal conductance, transpiration, and evaporation in a temperate deciduous forest, validated by carbonyl sulfide uptake, Biogeosciences, 14, 389-401, https://doi.org/10.5194/bg14-389-2017, 2017.

Wei, Y., Liu, S., Huntzinger, D. N., Michalak, A. M., Viovy, N., Post, W. M., Schwalm, C. R., Schaefer, K., Jacobson, A. R., Lu, C., Tian, H., Ricciuto, D. M., Cook, R. B., Mao, J., and Shi, X.: The North American Carbon Program Multi-scale Synthesis and Terrestrial Model Intercomparison Project - Part 2: Environmental driver data, Geosci. Model Dev., 7, 2875-2893, https://doi.org/10.5194/gmd-7-2875-2014, 2014.

Welp, L. R., Keeling, R. F., Meijer, H. A. J., Bollenbacher, A. F., Piper, S. C., Yoshimura, K., Francey, R. J., Allison, C. E., and Wahlen, M.: Interannual variability in the oxygen isotopes of atmospheric $\mathrm{CO}_{2}$ driven by El Niño, Nature, 477, 579-582, https://doi.org/10.1038/nature10421, 2011.

Whelan, M. E., Min, D. H. and Rhew, R. C.: Salt marsh vegetation as a carbonyl sulfide (COS) source to the atmosphere, Atmos. Environ., 73, 131-137, doi:10.1016/j.atmosenv.2013.02.048, 2013.

Whelan, M. E., Hilton, T. W., Berry, J. A., Berkelhammer, M., Desai, A. R., and Campbell, J. E.: Carbonyl sulfide exchange in soils for better estimates of ecosystem carbon uptake, Atmos. Chem. Phys., 16, 3711-3726, https://doi.org/10.5194/acp16-3711-2016, 2016.

Whelan, M. E., Lennartz, S. T., Gimeno, T. E., Wehr, R., Wohlfahrt, G., Wang, Y., Kooijmans, L. M. J., Hilton, T. W., Belviso, S., Peylin, P., Commane, R., Sun, W., Chen, H., Kuai, L., Mammarella, I., Maseyk, K., Berkelhammer, M., Li, K.-F., Yakir, D., Zumkehr, A., Katayama, Y., Ogée, J., Spielmann, F. M., Kitz, F., Rastogi, B., Kesselmeier, J., Marshall, J., Erkkilä, K.-M., Wingate, L., Meredith, L. K., He, W., Bunk, R., Launois, T., Vesala, T., Schmidt, J. A., Fichot, C. G., Seibt, U., Saleska, S., Saltzman, E. S., Montzka, S. A., Berry, J. A., and Campbell, J. E.: Reviews and syntheses: Carbonyl sulfide as a multi-scale tracer for carbon and water cycles, Biogeosciences, 15, 36253657, https://doi.org/10.5194/bg-15-3625-2018, 2018.

Whelan, M. E., Anderegg, L. D. L., Badgley, G., Elliott Campbell, J., Commane, R., Frankenberg, C., Hilton, T. W., Kuai, L., Parazoo, N., Shiga, Y., Wang, Y., and Worden, J.: Scientific communities striving for a common cause, B. Am. Meteorol. Soc., 101, 1537-1543, https://doi.org/10.1175/BAMS-D-19-0306.1, 2020.

Wohlfahrt, G., Brilli, F., Hörtnagl, L., Xu, X., Bingemer, H., Hansel, A., and Loreto, F.: Carbonyl sulfide (COS) as a tracer for canopy photosynthesis, transpiration and stomatal conductance: potential and limitations, Plant. Cell Environ., 35, 657667, https://doi.org/10.1111/j.1365-3040.2011.02451.x, 2012.

Yang, F., Qubaja, R., Tatarinov, F., Rotenberg, E., and Yakir, D.: Assessing canopy performance using carbonyl sul- 
fide measurements, Global Change Biol., 24, 3486-3498, https://doi.org/10.1111/gcb.14145, 2018.

Yin, X. and Struik, P. C.: $\mathrm{C}_{3}$ and $\mathrm{C}_{4}$ photosynthesis models: An overview from the perspective of crop modelling, NJAS-Wagen. J. Life Sc., 57, 27-38, https://doi.org/10.1016/j.njas.2009.07.001, 2009.
Zobler, L.: A World Soil File for Global Climate Modelling, in: NASA Technical Memorandum 87802, NASA Goddard Institute for Space Studies, New York, USA, 1986.

Zumkehr, A., Hilton, T. W., Whelan, M., Smith, S., Kuai, L., Worden, J., and Campbell, J. E.: Global gridded anthropogenic emissions inventory of carbonyl sulfide, Atmos. Environ., 183, 11-19, https://doi.org/10.1016/j.atmosenv.2018.03.063, 2018. 